May 2001 • NREL/TP-550-25873

\title{
Analysis of the Thermal Performance of Tierra I- A Low-Energy High-Mass Residence
}

\author{
Michael W. Smith
}

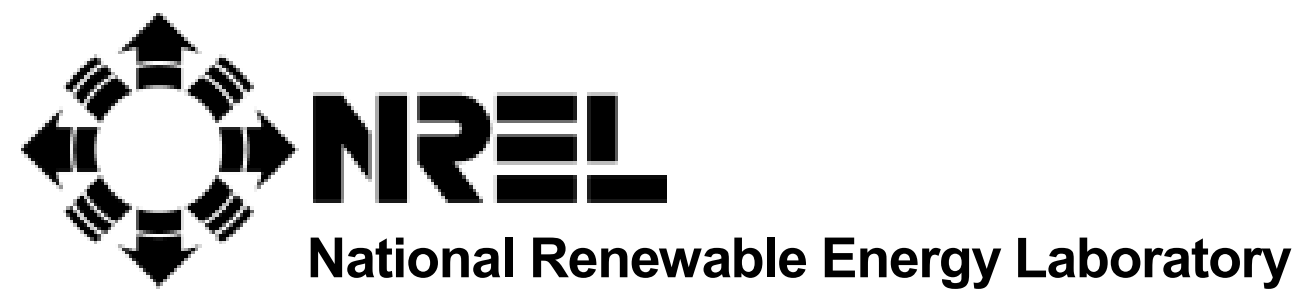

1617 Cole Boulevard

Golden, Colorado 80401-3393

NREL is a U.S. Department of Energy Laboratory

Operated by Midwest Research Institute $\bullet$ Battelle $\bullet$ Bechtel

Contract No. DE-AC36-99-G010337 
May 2001 • NREL/TP-550-25873

\section{Analysis of the Thermal Performance of Tierra I- A Low-Energy High-Mass Residence}

Michael W. Smith

Prepared under Task No. BET1.8004

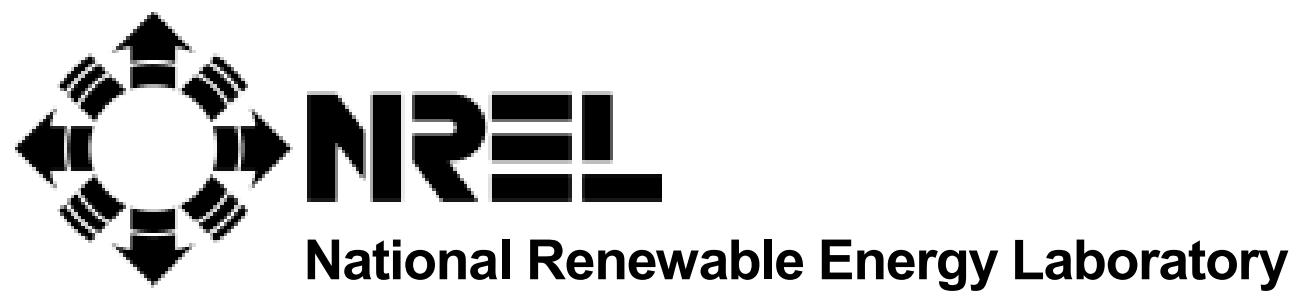

1617 Cole Boulevard

Golden, Colorado 80401-3393

NREL is a U.S. Department of Energy Laboratory

Operated by Midwest Research Institute • Battelle • Bechtel

Contract No. DE-AC36-99-G010337 


\section{NOTICE}

This report was prepared as an account of work sponsored by an agency of the United States government. Neither the United States government nor any agency thereof, nor any of their employees, makes any warranty, express or implied, or assumes any legal liability or responsibility for the accuracy, completeness, or usefulness of any information, apparatus, product, or process disclosed, or represents that its use would not infringe privately owned rights. Reference herein to any specific commercial product, process, or service by trade name, trademark, manufacturer, or otherwise does not necessarily constitute or imply its endorsement, recommendation, or favoring by the United States government or any agency thereof. The views and opinions of authors expressed herein do not necessarily state or reflect those of the United States government or any agency thereof.

Available electronically at http://www.doe.gov/bridge

Available for a processing fee to U.S. Department of Energy

and its contractors, in paper, from:

U.S. Department of Energy

Office of Scientific and Technical Information

P.O. Box 62

Oak Ridge, TN 37831-0062

phone: 865.576.8401

fax: 865.576.5728

email: reports@adonis.osti.gov

Available for sale to the public, in paper, from:

U.S. Department of Commerce

National Technical Information Service

5285 Port Royal Road

Springfield, VA 22161

phone: 800.553.6847

fax: 703.605.6900

email: orders@ntis.fedworld.gov

online ordering: http://www.ntis.gov/ordering.htm

Printed on paper containing at least $50 \%$ wastepaper, including $20 \%$ postconsumer waste 


\begin{abstract}
We designed a low-energy concrete house using passive solar strategies to consume $70 \%$ less heating and cooling energy than a base case that conformed to the 1996 Home Energy Rating System (HERS) and the 1995 Model Energy Code (MEC). The performance of this house was then evaluated using computer simulations and measured data.

The house, Tierra I, was monitored from July 22, 1996, through October 14, 1997. A Short Term Energy Monitoring (STEM) test was done November 19 to December 10, 1996. Computer simulations of the house were done using SUNREL, an updated version of the hourly data simulation package SERI-RES. The SUNREL model of the house was calibrated using both short- and long-term data.

The house achieved energy savings of $56 \%, 14 \%$ below the goal of $70 \%$. The lower-than-expected savings resulted from problems with the window modeling. As a result, during the design phase the solar gains were overestimated, causing an underestimate in the level of insulation necessary to achieve the savings goal. For very low-energy passive solar buildings, it is apparent that very accurate window modeling is required. It also became apparent that accurate ground models are required as well because ground-heat loss accounts for a significant portion of the total heat loss in low-energy buildings. In general, as we design lower and lower energy buildings, the overall accuracy of modeling becomes more and more critical. The current generation of building energy simulation programs needs algorithm improvements with respect to some mechanisms of heat transfer.
\end{abstract}

\title{
Acknowledgments
}

The National Renewable Energy Laboratory's High-Performance Buildings Research Project provided support for the energy design of the building described in this report. The Department of Energy provided funding for this activity from the Office of Building Technology, State and Community Programs.

Special thanks to Ron Judkoff and Paul Torcellini for their assistance and guidance with this project. Thanks also to Toni Smith and Sheila Hayter for their suggestions and help with editing. 


\section{Table Of Contents}

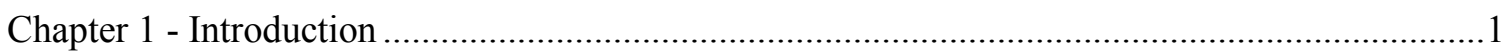

1.1 Background on Residential Energy Use and Conservation ..........................................

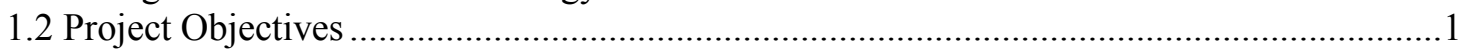

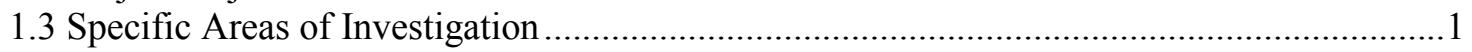

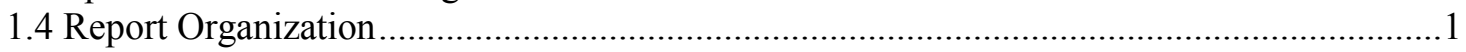

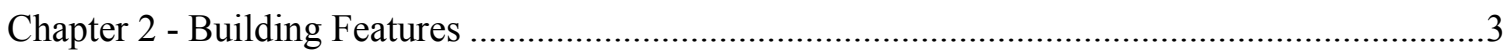

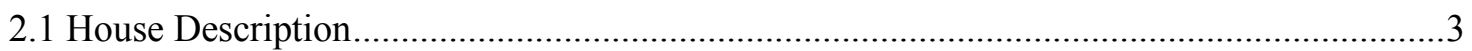

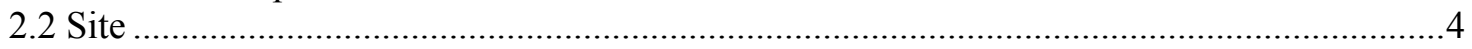

2.3 Climate.

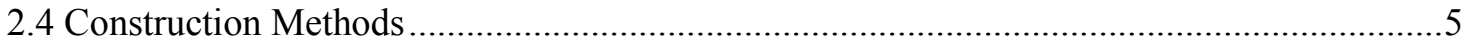

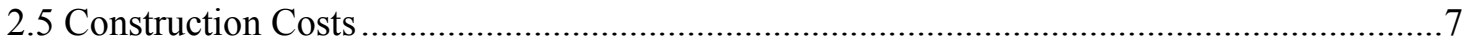

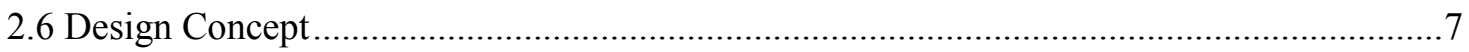

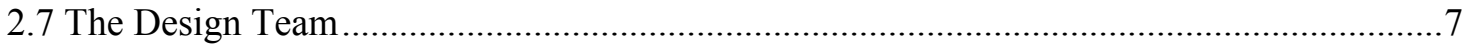

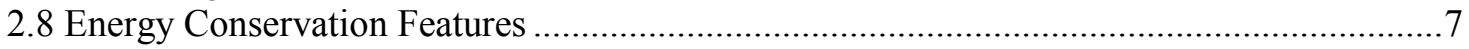

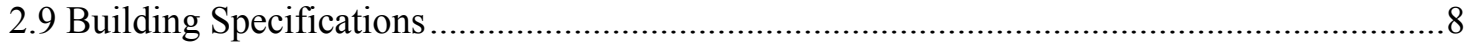

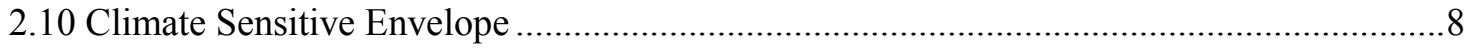

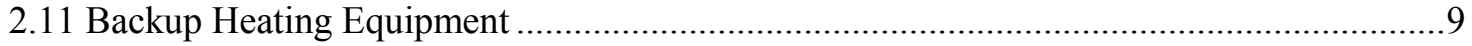

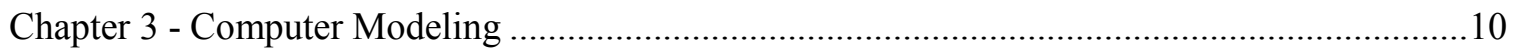

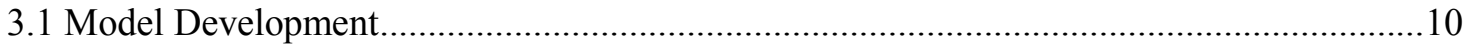

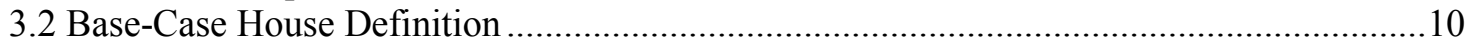

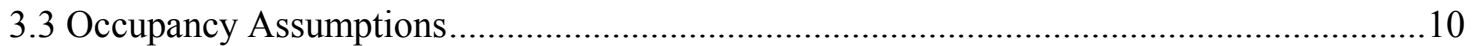

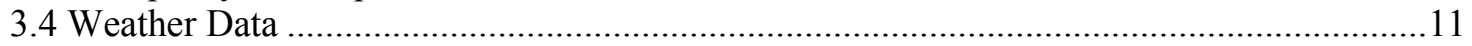

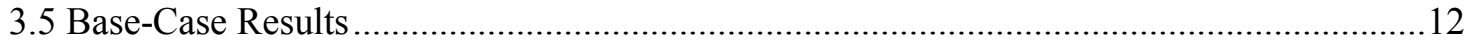

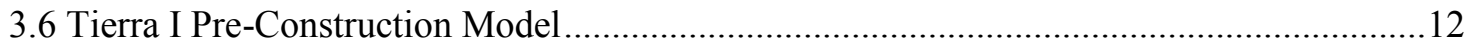

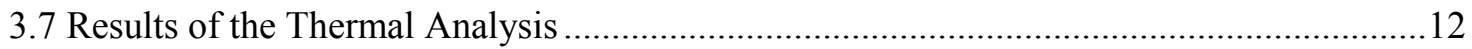

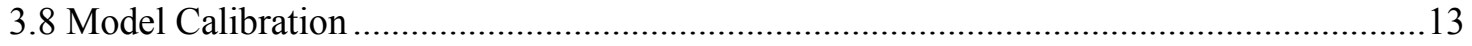

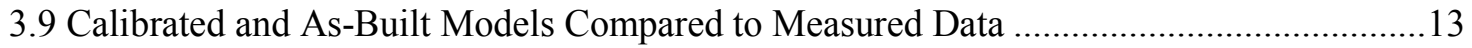

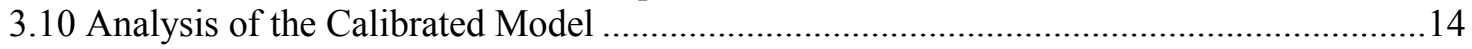

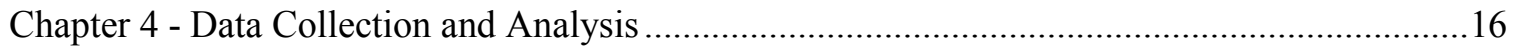

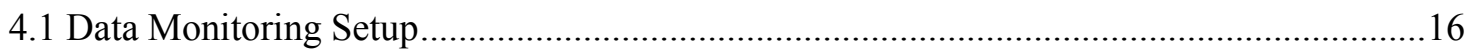

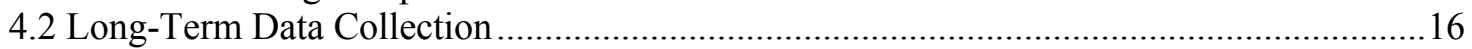

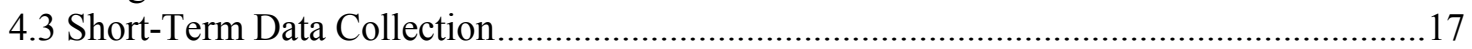

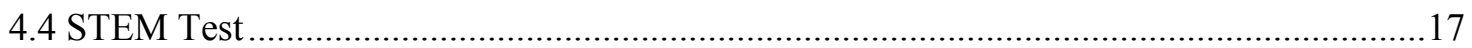

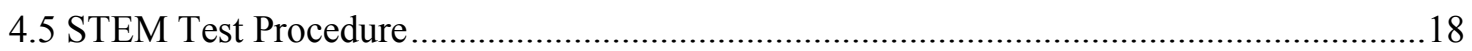

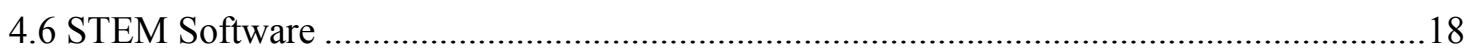

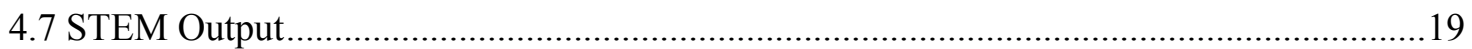

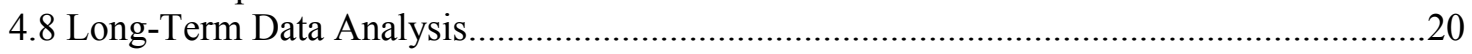

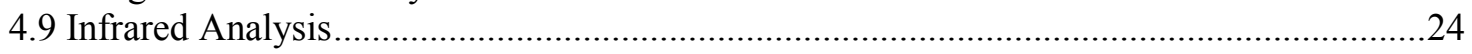




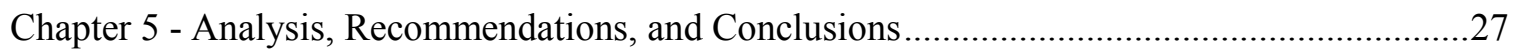

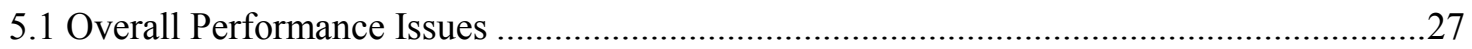

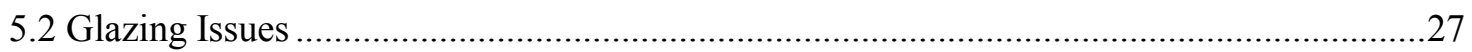

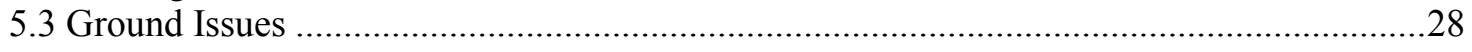

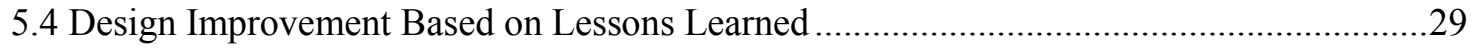

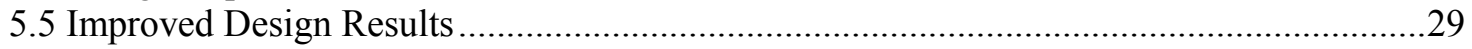

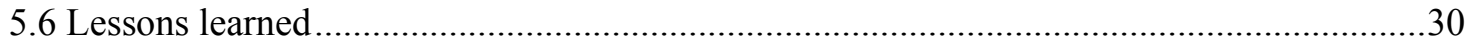

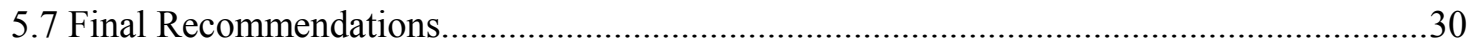

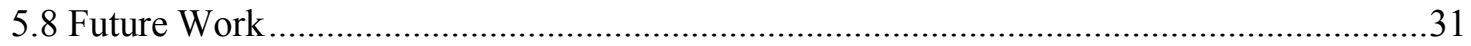

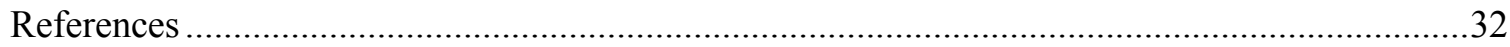

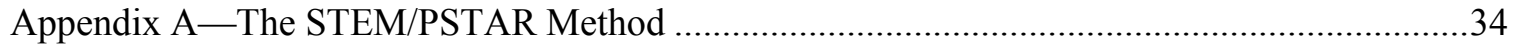

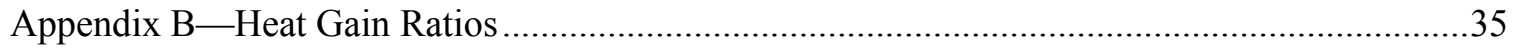

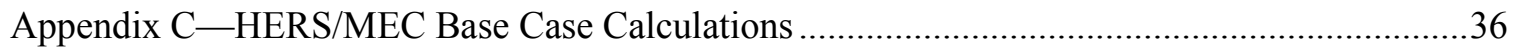

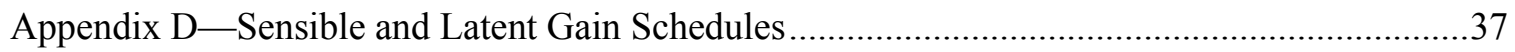

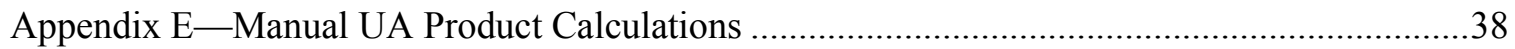

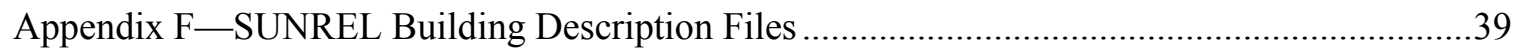

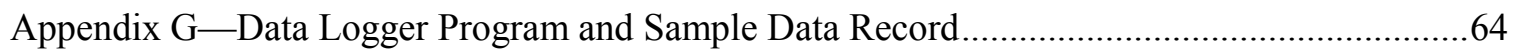

Appendix H-Temperature Profiles and Precipitation Graphs .................................................68

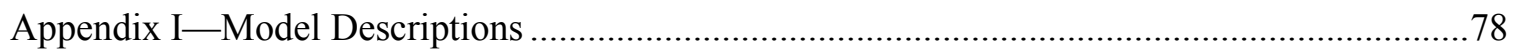

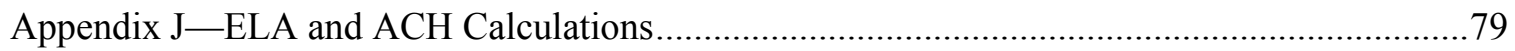




\section{List of Tables}

Table 1. Solar Radiation and Temperature Information........................................................4

Table 2. Monthly Weather Data Showing Wind Speed, Dew Point, Humidity

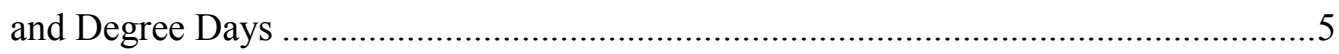

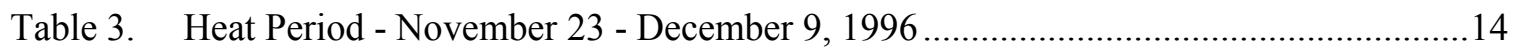

Table 4. Float Period - January 1 - October 13, 1997 ............................................................... 14

Table 5. Coast Period Monthly Temperature Error....................................................................14

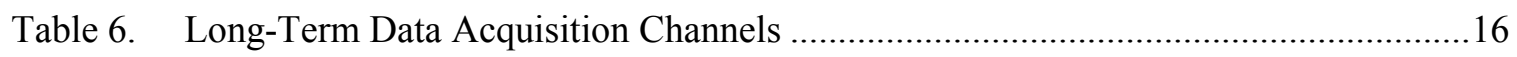

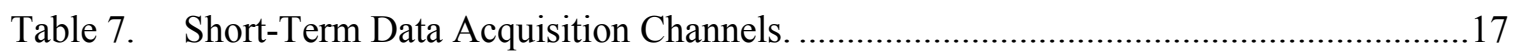

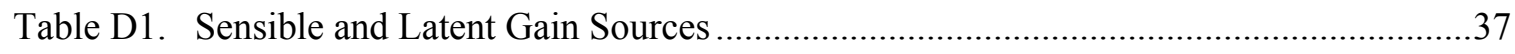

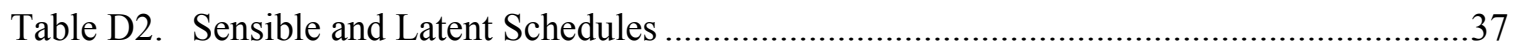

Table E1. UA Product for Individual Components and the Whole Building ...............................38

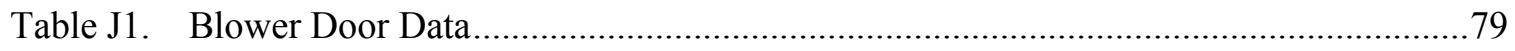




\section{List of Figures}

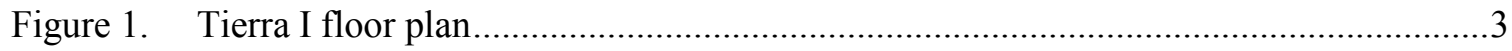

Figure 2. Tierra I - south side showing the garage (left) and main house with clerestory (right) 3

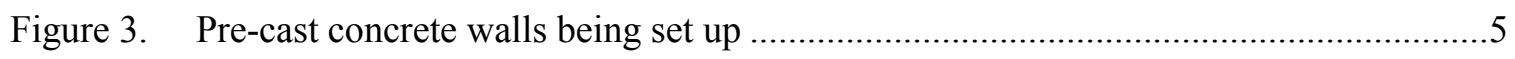

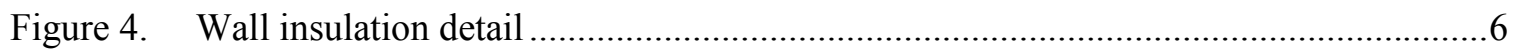

Figure 5. Dumpster with all construction waste including that from framing and drywall.........6

Figure 6. Overhangs shading south glazing in summer .....................................................

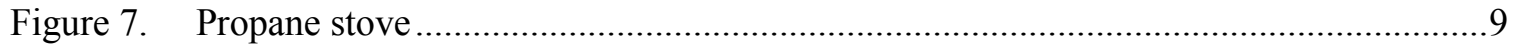

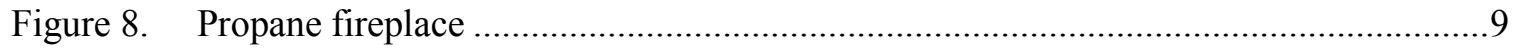

Figure 9. Average monthly global horizontal radiation .......................................................11

Figure 10. Average monthly outdoor temperature …...............................................................12

Figure 11. Base case and pre-construction model energy load comparison.................................13

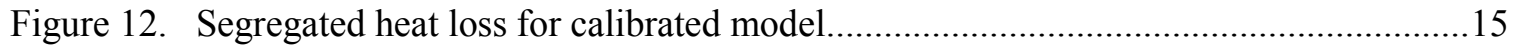

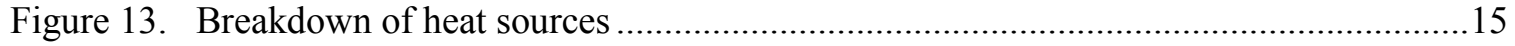

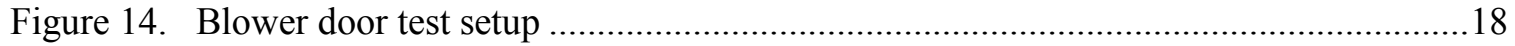

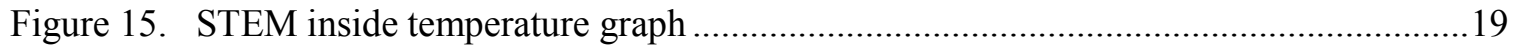

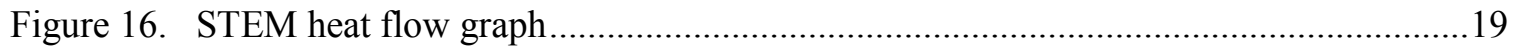

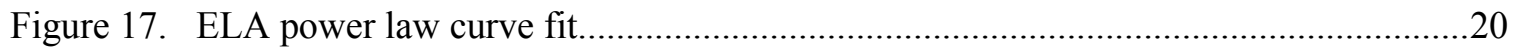

Figure 18. November to October indoor and outdoor temperature profiles ...............................21

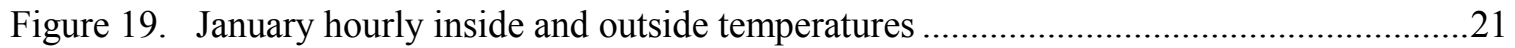

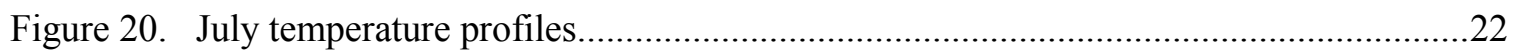

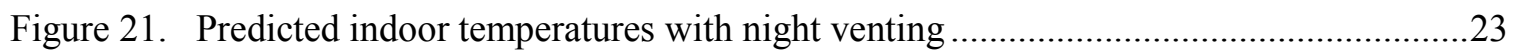

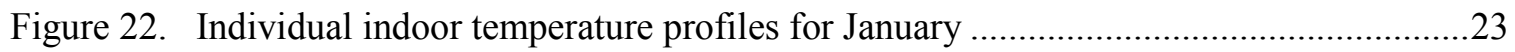

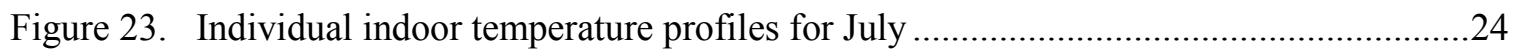

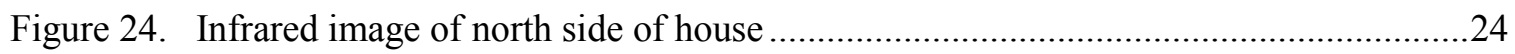

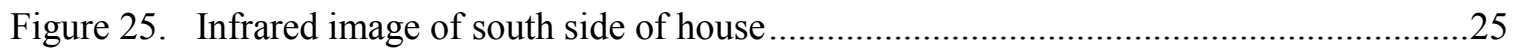

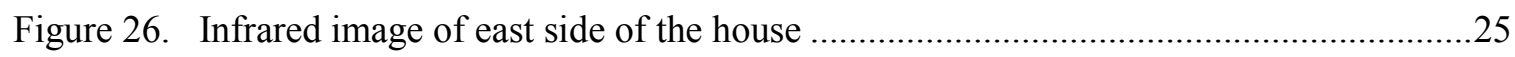

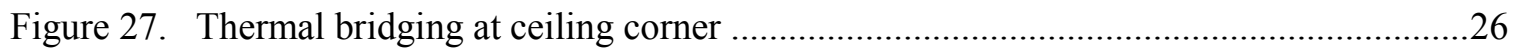

Figure 28. Thermal bridging at roof penetration of chimney and at window frame ...................26

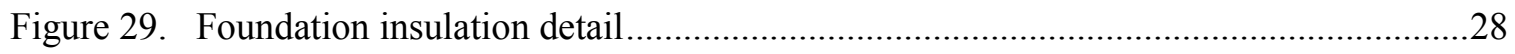

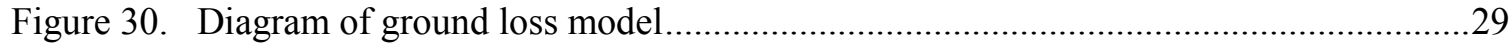

Figure 31. Breakdown of heat loss in improved design model. ..............................................30 
Figure H1. Measured and modeled indoor temperature profiles during STEM period .68

Figure H2. Snow and rainfall levels during STEM period.....................................................6

Figure H3. Measured and modeled indoor temperature profiles for January 1997.....................69

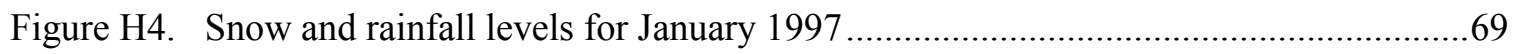

Figure H5. Measured and modeled indoor temperature profiles for February 1997 ....................70

Figure H6. Snow and rainfall levels for February 1997 ........................................................ 70

Figure H7. Measured and modeled indoor temperature profiles for March 1997 ........................71

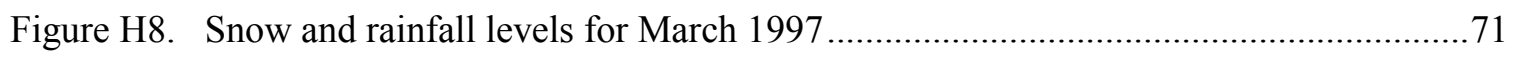

Figure H9. Measured and modeled indoor temperature profiles for April 1997..........................72

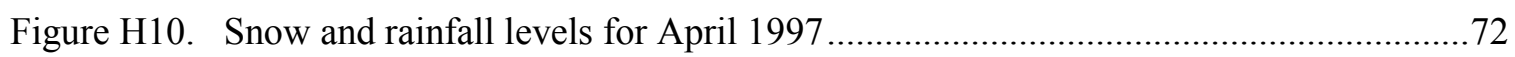

Figure H11. Measured and modeled indoor temperature profiles for May 1997 ........................73

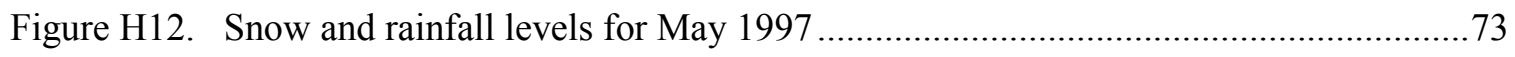

Figure H13. Measured and modeled indoor temperature profiles for June 1997 ….....................74

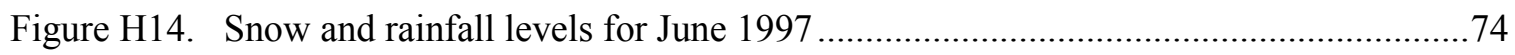

Figure H15. Measured and modeled indoor temperature profiles for July 1997 ........................75

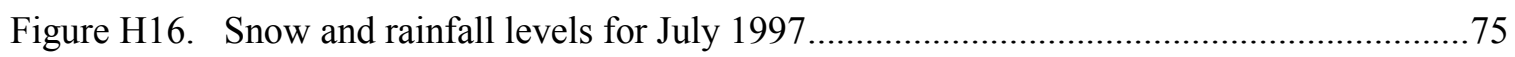

Figure H17. Measured and modeled indoor temperature profiles for August 1997.....................76

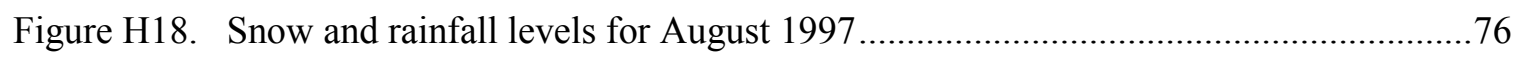

Figure H19. Measured and modeled indoor temperature profiles for September 1997 ...............77

Figure H20. Snow and rainfall levels for September 1997 ..................................................... 77 


\section{Chapter 1 - Introduction}

\subsection{Background on Residential Energy Use and Conservation}

The energy crisis of the 1970s resulted in the development of a comprehensive energy policy to produce long-term solutions. The goals of the policy were: "adequate energy supplies, reduced dependence on energy imports, protection against the disruption of foreign supplies, and increased conservation and efficiency in end uses." Residential buildings use 57\% of U.S. buildings' total energy, with single-family detached homes accounting for $71 \%$ of that total. This represents 11.07 quadrillion Btu at a cost of $\$ 68.86$ billion in 1987 dollars. Heating and air-conditioning accounts for $43 \%$ of total residential energy use, appliances account for a further $40 \%$, and the rest is used for heating water. Reducing energy in detached homes through energy efficiency and passive solar design would have a significant impact on total building energy consumption [1].

\subsection{Project Objectives}

Tierra I is the first in a series of technical evaluations with the objective of designing, building, and evaluating a high-mass passive solar house that uses $70 \%$ less heating and cooling energy than a Home Energy Rating Council (HERS)[2] Model Energy Code (MEC)[3] base case house. An energy computer simulation was used to evaluate design options. This process is documented in Tierra Concrete Homes: Low-Energy Residential Building Design [4].

\subsection{Specific Areas of Investigation}

The objectives of this report are follows:

1. Describe the design and construction methods used for Tierra I.

2. Quantify the performance of Tierra I using short- and long-term data.

3. Model the house and determine base case heating and cooling loads using the hourly simulation package SUNREL. [5]

4. Examine the differences between the computer model predictions and measured performance.

5. Determine areas of success as well as those areas requiring further work to meet the goals of a house using 70\% less heating and cooling energy than a HERS/MEC base case.

\subsection{Report Organization}

Chapter 2 describes the house, the site, and the climate. It also provides construction details and costs.

Chapter 3 describes the computer simulation work. It compares the base case energy use with the estimated energy use of the simulated design model. It also discusses the differences from design results and provides information on calibrating the model based on the measured data.

The long- and short-term data collection and instrumentation are discussed in Chapter 4. The Short Term Energy Monitoring (STEM) data are used to evaluate the solar performance and the building thermal envelope. The long-term data are examined to determine the energy performance of the house and compare it with modeled data. A section on infrared analysis corroborates the findings on the house's thermal envelope performance. 
Chapter 5 discusses several issues resulting from monitoring and modeling the house. The section on reoptimization shows that the $70 \%$ savings goal could be achieved with more insulation. This chapter also summarizes the results and conclusions. 


\section{Chapter 2 - Building Features}

\subsection{House Description}

The Tierra I concrete house is a single-story, three-bedroom ranch design that maximizes solar gain by orienting the long axis of the house east-west (see Figure 1). A clerestory increases the passive solar collection area and provides daylighting for the northern half of the house. The total living area is $1,870 \mathrm{ft}^{2}\left(174 \mathrm{~m}^{2}\right)$ with a two-car garage attached to the west side of the house (see Figure 2).

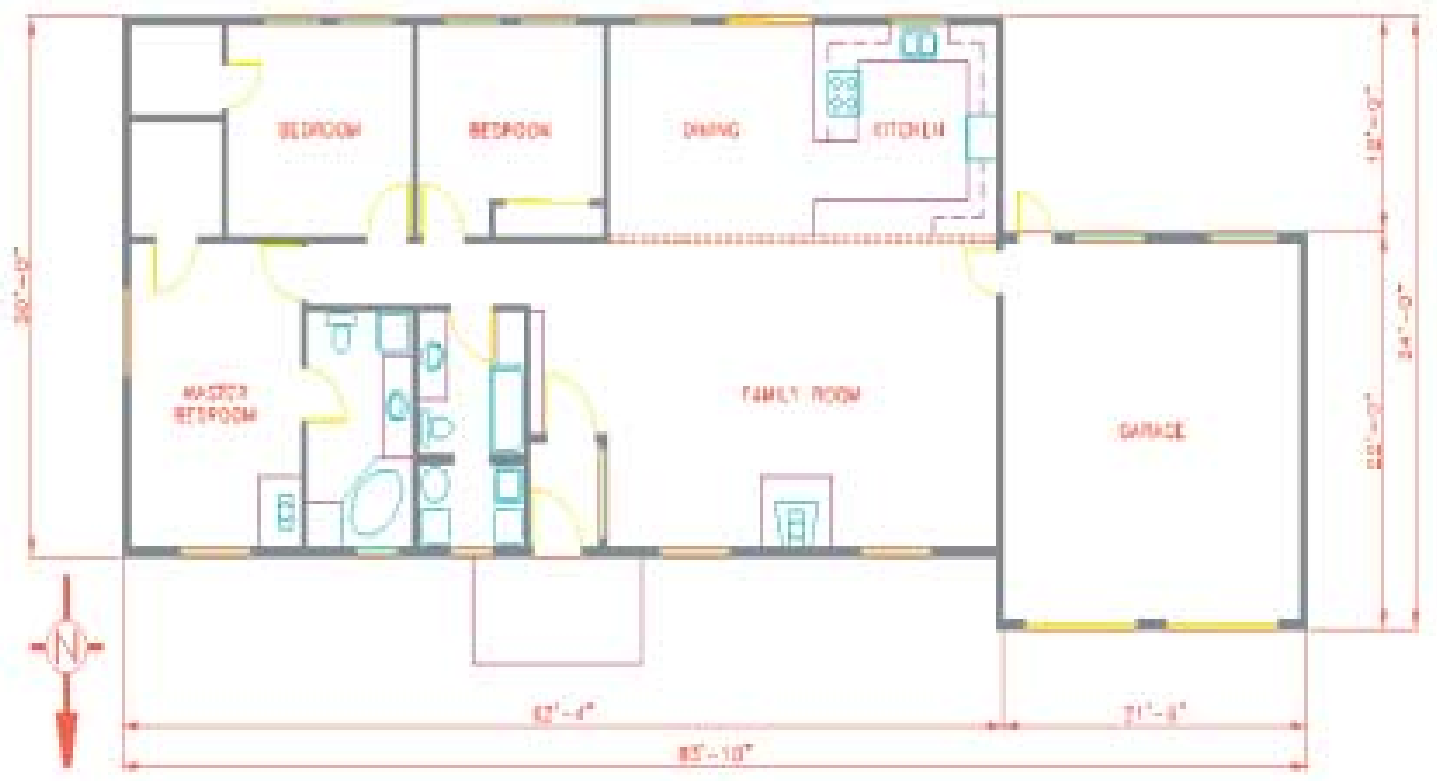

Figure 1. Tierra I floor plan

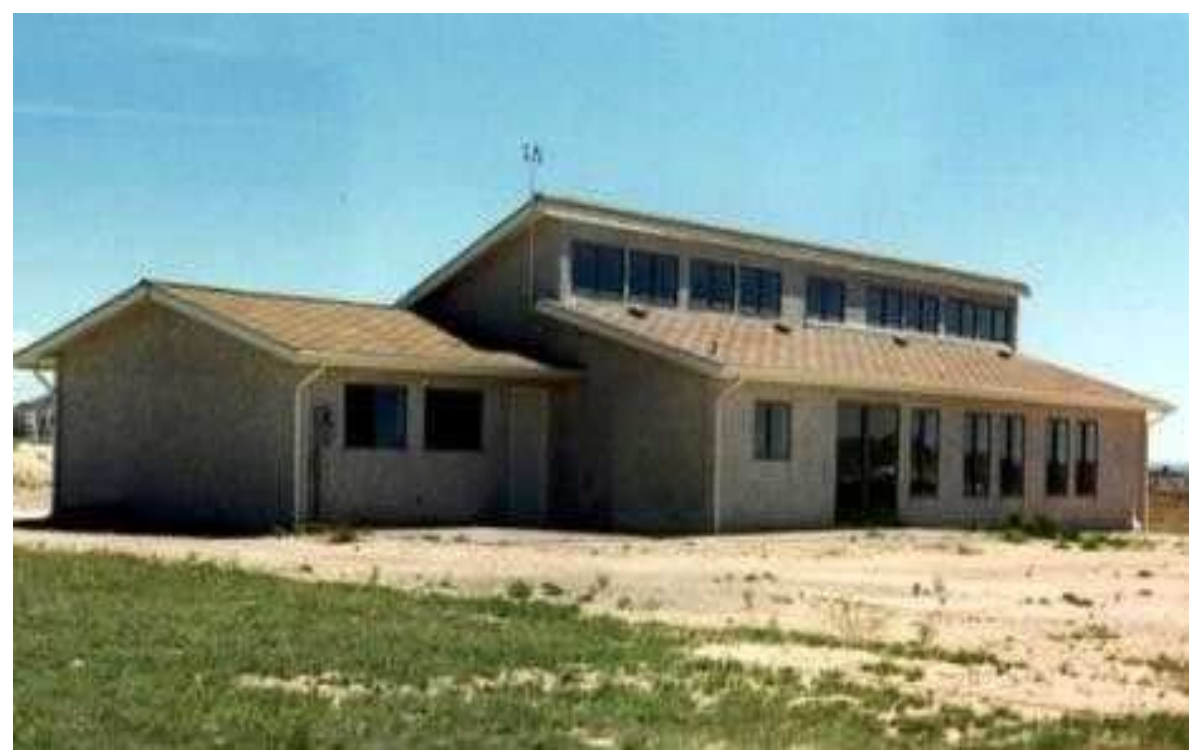

Figure 2. Tierra l-south side showing the garage (left) and main house with clerestory (right) 


\subsection{Site}

Tierra I was constructed by Tierra Concrete homes in West Pueblo, Colorado. The elevation is 4,950 ft $(1,509 \mathrm{~m})$, the latitude is $38.18^{\circ} \mathrm{N}$, and the longitude is $104.3^{\circ} \mathrm{W}$. The building lot is flat with sparse vegetation, and there are large open areas between the neighboring houses. Landmasses and neighboring buildings do not provide any shading to the site.

\subsection{Climate}

Pueblo's climate is mild with moderate temperatures throughout the year. The 30 -year average daily high is $68.6^{\circ} \mathrm{F}\left(20.3^{\circ} \mathrm{C}\right)$ and the average daily low is $36.8^{\circ} \mathrm{F}\left(2.7^{\circ} \mathrm{C}\right)$. There are 5,413 heating-degree-days $\left(65^{\circ} \mathrm{F}\right.$ base $)$ and 973 cooling-degree-days $\left(65^{\circ} \mathrm{F}\right.$ base $)$. The average daily solar radiation incident on an unshaded horizontal surface is $1,570 \mathrm{Btu} / \mathrm{ft}^{2}\left(17,835 \mathrm{~kJ} / \mathrm{m}^{2}\right)$.[6]

Table 1 shows monthly solar radiation and ambient temperature statistics. Table 2 contains statistics on wind speed, humidity ratio, ground temperature, and degree days. The information in both tables is from the output of SUNREL (the simulation package used for modeling in this report) and is derived from the Pueblo Typical Meteorological Year (TMY) weather files [6].

Table 1. Solar Radiation and Temperature Information

\begin{tabular}{|c|c|c|c|c|c|c|c|c|c|}
\hline & \multicolumn{5}{|c|}{ Solar Radiation } & \multicolumn{4}{|c|}{ Temperature } \\
\hline & Direct & Unshaded & Direct & Diffuse & Total & Mean & Min. & Max. & Range \\
\hline & Normal & Horizontal & Horizontal & Horizontal & Horizontal & & & & \\
\hline Month & $\mathrm{kBtu} / \mathrm{ft}^{2}$ & $\mathrm{kBtu} / \mathrm{ft}^{2}$ & $\mathrm{kBtu} / \mathrm{ft}^{2}$ & $\mathrm{kBtu} / \mathrm{ft}^{2}$ & $\mathrm{kBtu} / \mathrm{ft}^{2}$ & ${ }^{\circ} \mathrm{F}$ & ${ }^{\circ} \mathrm{F}$ & ${ }^{\circ} \mathrm{F}$ & ${ }^{\circ} \mathrm{F}$ \\
\hline JAN & 55.42 & 26.96 & 21.08 & 5.88 & 26.96 & 26.9 & -25.1 & 64.9 & 28.5 \\
\hline FEB & 54.48 & 32.90 & 25.07 & 7.83 & 32.90 & 34.8 & -18.0 & 75.9 & 29.3 \\
\hline MAR & 64.48 & 50.01 & 35.66 & 14.35 & 50.01 & 38.1 & -8.0 & 78.1 & 26.5 \\
\hline APR & 62.55 & 58.19 & 40.34 & 17.85 & 58.19 & 50.5 & 16.0 & 79.0 & 27.5 \\
\hline MAY & 67.72 & 68.99 & 47.89 & 21.10 & 68.99 & 62.1 & 34.0 & 88.0 & 29.0 \\
\hline JUN & 76.42 & 75.09 & 55.99 & 19.10 & 75.09 & 71.2 & 46.9 & 95.0 & 30.7 \\
\hline JUL & 72.65 & 71.71 & 53.37 & 18.34 & 71.71 & 75.6 & 55.9 & 97.0 & 27.7 \\
\hline AUG & 70.07 & 64.13 & 47.95 & 16.18 & 64.13 & 74.7 & 55.0 & 100.0 & 29.1 \\
\hline SEP & 63.55 & 52.28 & 38.59 & 13.69 & 52.28 & 65.8 & 33.1 & 96.1 & 28.9 \\
\hline OCT & 64.62 & 42.89 & 32.33 & 10.56 & 42.89 & 56.7 & 28.0 & 88.0 & 34.6 \\
\hline NOV & 52.46 & 28.83 & 21.53 & 7.30 & 28.83 & 42.1 & 19.0 & 72.0 & 29.5 \\
\hline DEC & 52.70 & 24.83 & 19.04 & 5.79 & 24.83 & 34.6 & 0.0 & 69.1 & 33.9 \\
\hline TOT & 757.12 & 596.79 & 438.84 & 157.96 & 596.79 & 52.8 & -25.1 & 100.0 & 29.6 \\
\hline
\end{tabular}


Table 2. Monthly Weather Data Showing Wind Speed, Dew Point, Humidity, and Degree Days

\begin{tabular}{|c|c|c|c|c|c|c|c|}
\hline & \multicolumn{3}{|c|}{ Wind Speed } & & Humidity & \multicolumn{2}{|c|}{ Degree Days } \\
\hline & Mean & Min. & Max. & Dew Point & Ratio & Heating & Cooling \\
\hline & & & & & & $65^{\circ} \mathrm{F}$ Base & $65^{\circ} \mathrm{F}$ Base \\
\hline Month & Mph & Mph & Mph & ${ }^{\circ} \mathrm{F}$ & & & \\
\hline JAN & 6.4 & 0 & 36.9 & 16.6 & 0.0025 & 1151.8 & 0.0 \\
\hline FEB & 8.6 & 0 & 27.7 & 17.9 & 0.0025 & 828.2 & 0.0 \\
\hline MAR & 8.2 & 0 & 42.5 & 22.7 & 0.0032 & 822.2 & 0.0 \\
\hline APR & 10.9 & 0 & 28.9 & 27.2 & 0.0038 & 450.7 & 0.0 \\
\hline MAY & 12.2 & 0 & 34.4 & 32.4 & 0.0049 & 141.8 & 32.3 \\
\hline JUN & 11.4 & 0 & 28.9 & 42.3 & 0.0071 & 8.0 & 168.8 \\
\hline JUL & 9.2 & 0 & 38.0 & 48.2 & 0.0088 & 0.0 & 320.2 \\
\hline AUG & 7.6 & 0 & 42.5 & 50.2 & 0.0094 & 0.0 & 309.8 \\
\hline SEP & 9.1 & 0 & 40.3 & 40.6 & 0.0066 & 111.1 & 127.1 \\
\hline OCT & 7.9 & 0 & 38.0 & 24.5 & 0.0033 & 248.3 & 9.0 \\
\hline $\mathrm{NOV}$ & 7.6 & 0 & 30.0 & 21.3 & 0.0028 & 643.2 & 0.0 \\
\hline DEC & 8.3 & 0 & 34.4 & 13.6 & 0.0020 & 902.2 & 0.0 \\
\hline TOT & 8.9 & 0 & 42.5 & 29.9 & 0.0048 & 5307.7 & 967.3 \\
\hline
\end{tabular}

\subsection{Construction Methods}

Tierra I was constructed with pre-cast concrete walls (see Figure 3). Most of the exterior and interior walls were poured off site and transported to the building location, where a crane lifted them into place. The pre-cast walls included openings for doors, windows, electrical conduit, and outlet boxes. All interior wall surfaces were finished to look and feel like drywall. The roof is constructed with raised-heel trusses, drywall ceiling, and blown-in fiberglass insulation.

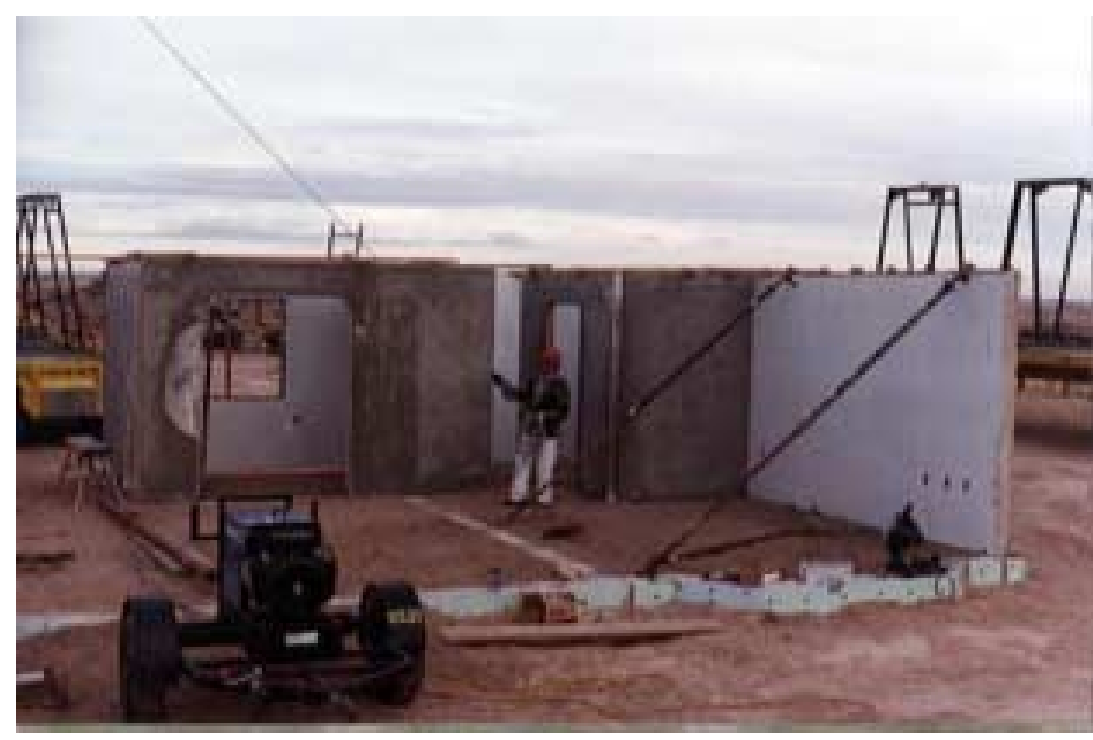

Figure 3. Pre-cast concrete walls being set up 
Polyisocyanurate insulation was secured to the outside surface using connectors (see Figure 4) when the walls were being cast. This was done by first laying the insulation down with inserted clasps. The concrete was then poured over the insulation and hardened around the clasps. Once on site, a concretebased stucco finish was applied to the outside of the insulation on a mesh secured to the clasps. Other finishes, such as face brick or siding, may also be applied.

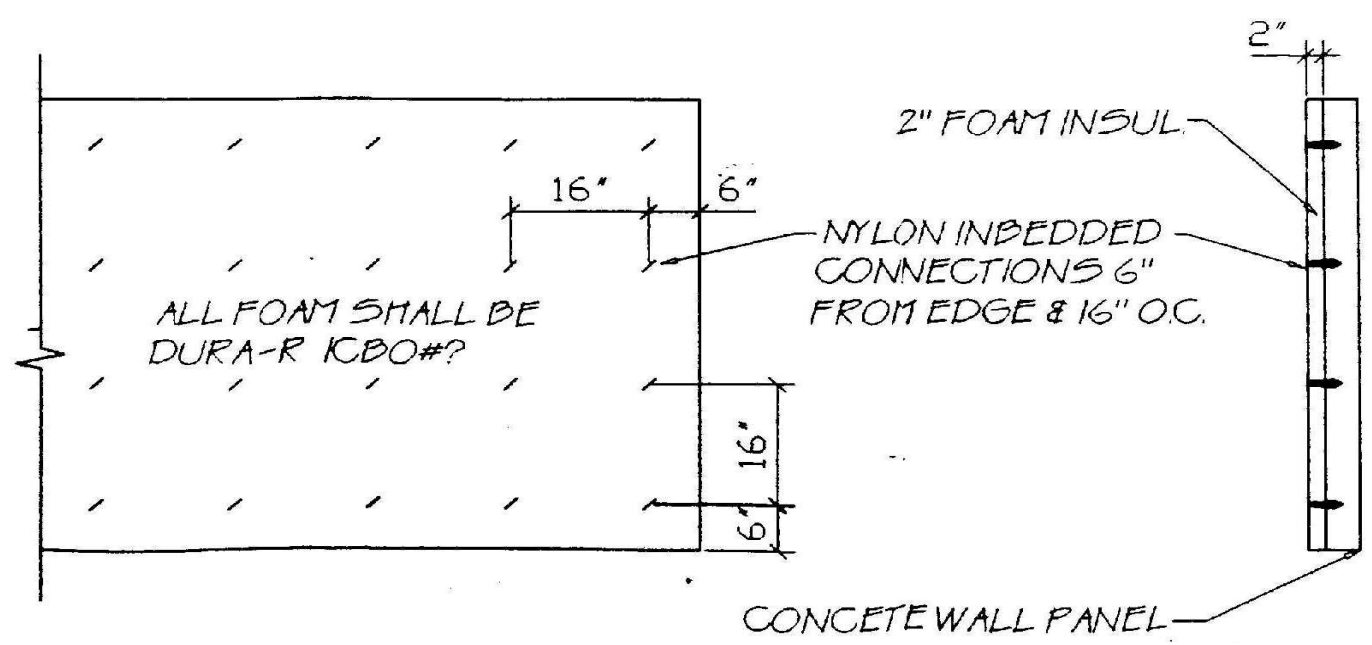

Figure 4. Wall insulation detail

Tierra Concrete Homes buys leftover and returned concrete from a local concrete plant. Returned concrete is poured into wall forms at the concrete plant rather than discarding the concrete or creating river riprap. Tierra purchases enough waste concrete to complete one house per week. Another feature is minimal construction waste (see Figure 5) because the walls include insulation and interior finish and minimal drywall and framing is used.

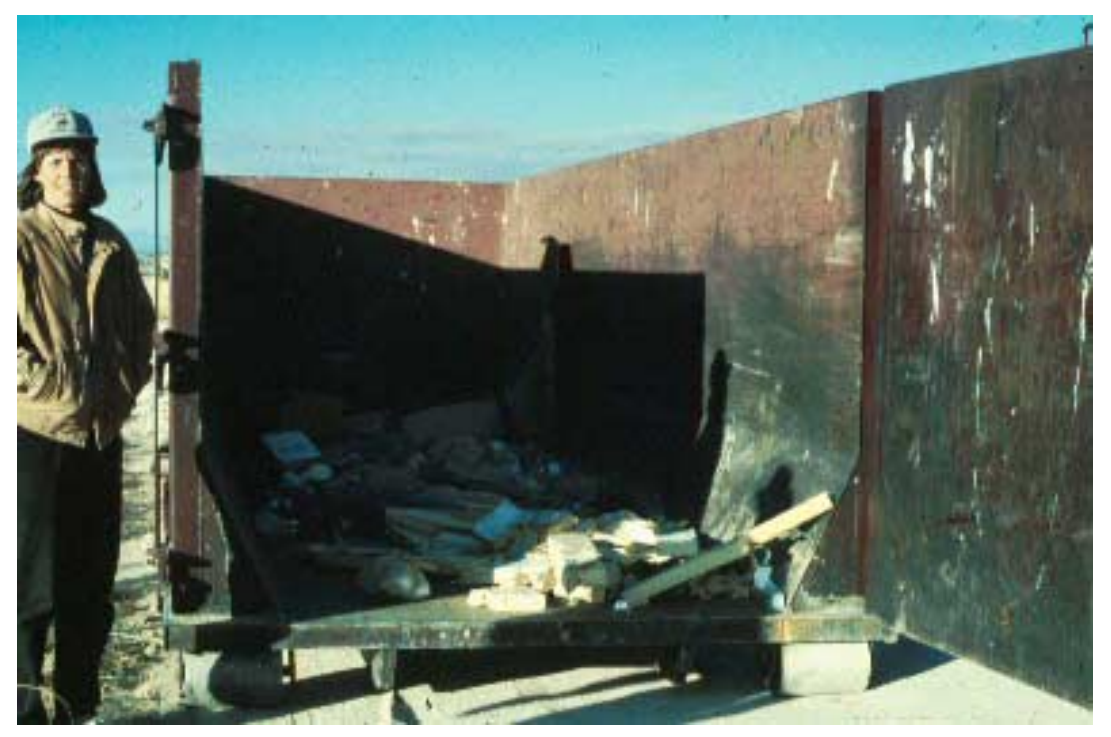

Figure 5. Dumpster with all construction waste including that from framing and drywall 


\subsection{Construction Costs}

At $\$ 75 / \mathrm{ft}^{2}\left(\$ 807 / \mathrm{m}^{2}\right)$, excluding land, the cost of this passive solar concrete home is similar to that of other custom homes in the area, which cost $\$ 75$ to $\$ 82 / \mathrm{ft}^{2}$ ( $\$ 807$ to $\$ 883 / \mathrm{m}^{2}$ ). Insulation costs (wall and perimeter) and the concrete walls are higher than the cost of typical wood-frame construction. In the Tierra house, the foundation (not insulated in typical Pueblo construction) costs $\$ 0.43 / \mathrm{ft}^{2}\left(\$ 4.73 / \mathrm{m}^{2}\right)$ to insulate, and the wall insulation costs $\$ 0.65 / \mathrm{ft}^{2}\left(\$ 7.00 / \mathrm{m}^{2}\right)$. This compares to $\$ 0.33 / \mathrm{ft}^{2}\left(\$ 3.55 / \mathrm{m}^{2}\right)$ for the wall insulation used in wood frame construction. However, significant savings are achieved through reduced construction time, limited use of drywall, and no central heating or cooling systems. A \$1,000 propane stove and a $\$ 1,000$ propane fireplace replace the conventional heating, ventilation, and airconditioning (HVAC) system with ductwork.

\subsection{Design Concept}

This section examines the design and the energy-efficient and solar energy features of the $1,870-\mathrm{ft}^{2}\left(174-\mathrm{m}^{2}\right)$ Tierra I house. The design is based on previous optimization work done on a smaller $1,120-\mathrm{ft}^{2}\left(104-\mathrm{m}^{2}\right)$ house design that was never built [4].

\subsection{The Design Team}

$\begin{array}{ll}\text { Architectural design: } & \text { MJC Consulting } \\ & \text { P.O. Box 1897 } \\ & \text { Pueblo, CO 81002-1897 } \\ & \text { (719) 546-2523 } \\ & \text { Tierra Concrete Homes } \\ & \text { P.O. Box 1924 } \\ \text { Energy design: } & \text { Pueblo, CO 81002 } \\ & \text { (719) 947-3040 } \\ & \text { National Renewable Energy Laboratory } \\ \text { Monitoring and testing: } & \text { Center for Buildings and Thermal Systems } \\ & \text { 1617 Cole Blvd. } \\ & \text { Golden, CO 80401 } \\ & \text { (303) 384-7538 }\end{array}$

\subsection{Energy Conservation Features}

- Air tightness: The concrete construction has little leakage, thus reducing energy loss resulting from infiltration. The design infiltration rate of the Tierra I house was 0.25 air changes per hour $(\mathrm{ACH})$ and the measured rate is $0.2 \mathrm{ACH}$ (see section 4.7).

- Daylighting: The design allows more daylight into the house to offset electric-light use and to promote a more pleasant atmosphere.

- Natural ventilation: The house uses natural ventilation to circulate cool night air during the summer, which is stored in the concrete to provide cooling during the day.

- Shading: Overhangs are sized to shade windows from direct summer solar gains, thereby reducing cooling loads.

- Solar heating: The building is oriented to maximize solar gain, which offsets heating loads.

- Thermal capacitance: The large interior concrete mass stores heat in winter and cold during the summer, which provides thermal comfort by reducing temperature swings.

- Windows: The windows are selected by their thermal resistance and shading coefficient (SC) for optimal thermal performance. 


\subsection{Building Specifications}

A key aspect of energy-efficient building design is reducing energy use. Insulation is fundamental because it reduces heat loss in winter and heat gain in summer. Insulation levels for Tierra I are based on the levels determined during the design process. The roof sections are pre-engineered raised heel-trusses with R-38 $\mathrm{ft}^{2} \cdot{ }^{\circ} \mathrm{F} \cdot \mathrm{hr} / \mathrm{Btu}\left(6.70 \mathrm{~m}^{2} \cdot \mathrm{K} / \mathrm{W}\right)$ cellulose insulation. The wall insulation is $\mathrm{R}-14 \mathrm{ft}^{2} \cdot{ }^{\circ} \mathrm{F} \cdot \mathrm{hr} / \mathrm{Btu}$ $\left(6.70 \mathrm{~m}^{2} \cdot \mathrm{K} / \mathrm{W}\right)$. Windows are double-pane, low-E, with a rated $\mathrm{SC}$ of 0.84 and a U-value of $0.35 \mathrm{Btu} / \mathrm{hr} \cdot \mathrm{ft}^{2} \cdot{ }^{\circ} \mathrm{F}$ $\left(2.16 \mathrm{~W} / \mathrm{m}^{2} \cdot \mathrm{K}\right)$. The window specification required a trade-off between energy conservation (low U-value) and the desire for high solar gains (high SC). See Appendix B for a description of SC.

Additional energy savings are achieved through low infiltration levels. The concrete construction and solid insulation provide an airtight building with a measured value of $0.2 \mathrm{ACH}$. This translates to about $62 \mathrm{cfm}(29 \mathrm{~L} / \mathrm{s})$ of outside air for Tierra I, which satisfies the American Society of Heating, Refrigeration, and Air-conditioning Engineers (ASHRAE) standard 62-1989 [7] requirements of $60 \mathrm{cfm}(28 \mathrm{~L} / \mathrm{s})$ for this house.

Energy-efficient, compact fluorescent lighting fixtures were installed throughout the home to reduce electric loads and, consequently, cooling loads. The house also uses low-flow faucets and showerheads that save energy by reducing hot-water consumption. The property is xeriscaped [8] for low water usage.

\subsection{Climate Sensitive Envelope}

Tierra I's design incorporates solar concepts to decrease heating and cooling loads. The house is oriented with the long axis running east-west to maximize southerly sun exposure. Glazing on the south side captures sunlight from the low winter sun to passively heat the home. A clerestory on the south brings in additional heat and daylight to the north side of the house. Overhangs are used to shade the windows from direct sunlight in the summer (see Figure 6) to reduce cooling loads. Figure 2 shows that the overhangs completely shade the south windows in the summer, reducing unwanted solar gains. To prevent unwanted gains from the low afternoon sun during the summer, there are no west-facing windows.

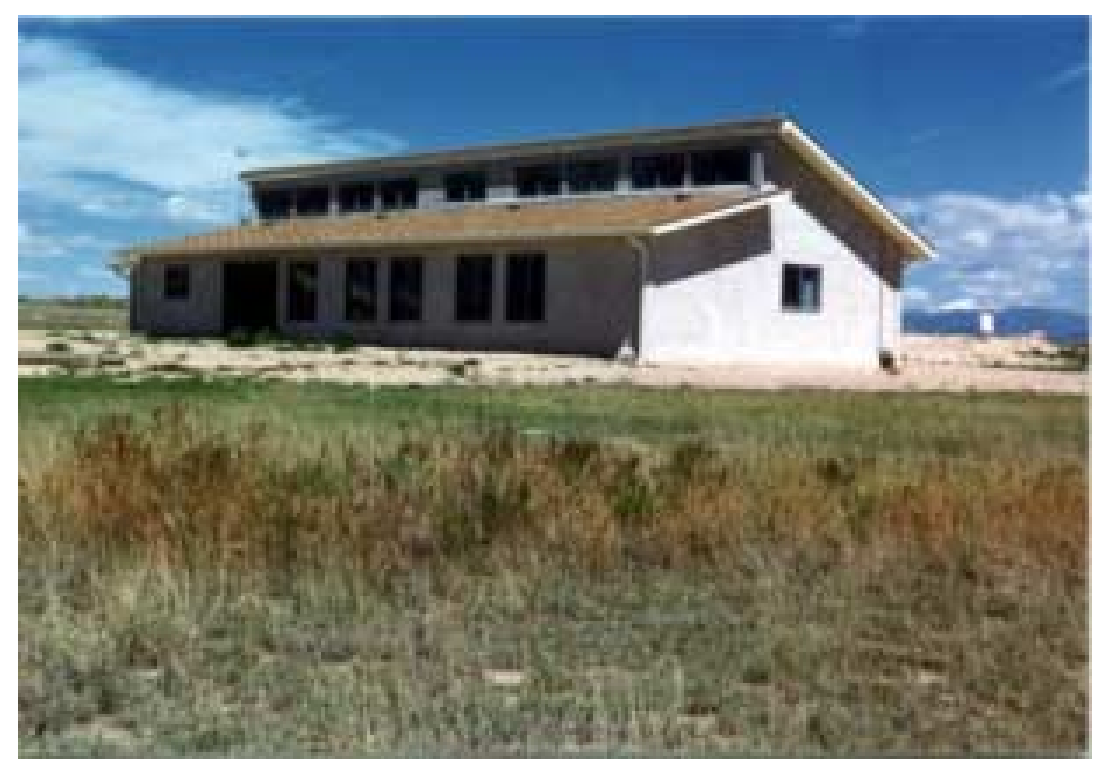

Figure 6. Overhangs shading south glazing in summer 
Concrete walls and floors act as heat storage for solar gain. During the winter, these massive surfaces absorb solar heat during the day and radiate it back at night. In the summer, the heat sink works to absorb excessive heat during the day and release it to the cooler night air using natural ventilation.

Tierra I was designed with an open floor plan to encourage natural air circulation. Ventilation cools the house by bringing in the cool night air during the summer. Windows can be opened and closed as needed to assist air circulation and provide natural ventilation. The clerestory windows can be opened to encourage a stack effect, increasing the natural ventilation. Ceiling fans, located in every room, provide additional air movement and supplement natural ventilation.

\subsection{Backup Heating Equipment}

As a result of reduced heat loss and by using passive solar heating techniques, Tierra I has a small heating load. Two thermostat-controlled gas-fired units meet the heating load and code requirements for an automatic heating system. One unit is a propane gas stove (see Figure 7) and the other unit is a propane fireplace (see Figure 8). Heat is circulated using natural convection and ceiling fans.

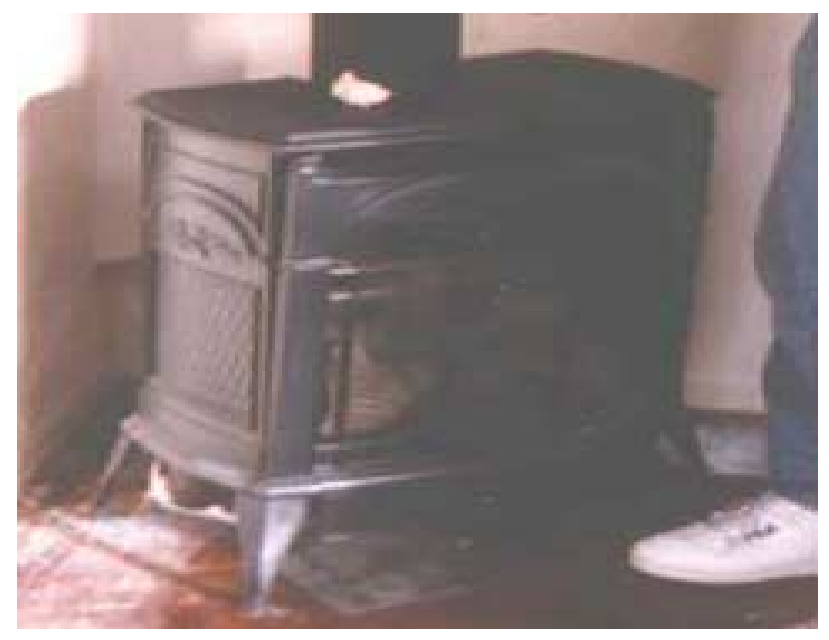

Figure 7. Propane stove

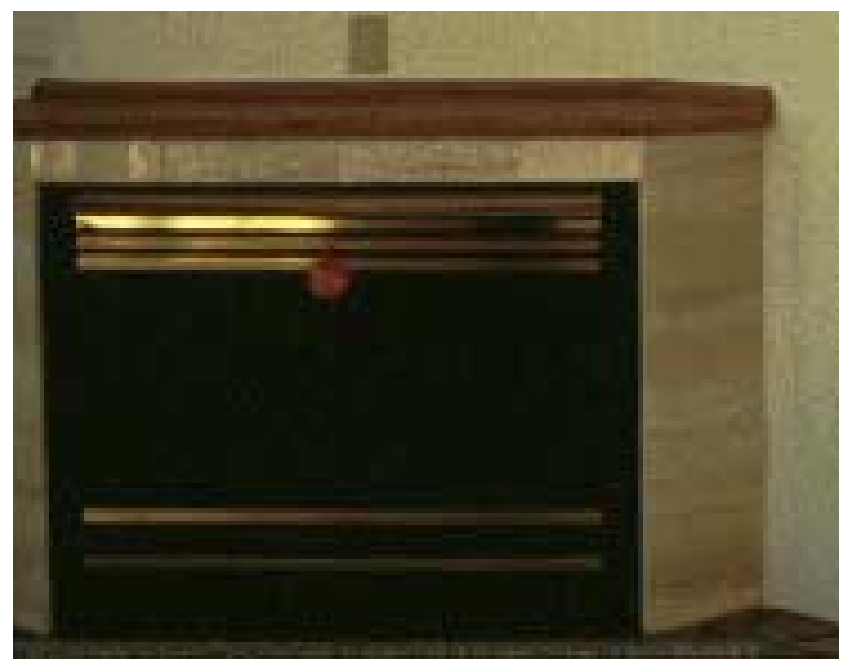

Figure 8. Propane fireplace 


\section{Chapter 3 - Computer Modeling}

\subsection{Model Development}

The performance of Tierra I was analyzed using the hourly energy simulation program SUNREL, an updated version of SERI-RES [9]. The first step in the process was to develop a base case model that met HERS and MEC guidelines. The base case simulation (model name: base case) provides the metric for judging Tierra I's performance. A pre-construction model (model name: pre-construction) was used to predict energy use and compare expected performance to the base case. After the house was built, the model was updated using the as-built characteristics (model name: as-built). The model was then calibrated (model name: calibrated) using measured data. Descriptions of all the models used are located in Appendix I.

\subsection{Base-Case House Definition}

The base-case house was modeled as a slab-on-grade, conventional wood-frame house with the same footprint as Tierra I. Working from the typical meteorological year (TMY) data file for Pueblo, the number of heating-degree-days on a $65^{\circ} \mathrm{F}\left(18.3^{\circ} \mathrm{C}\right)$ base was determined to be $5,308^{\circ} \mathrm{F}$.days, and the number of cooling-degree-days $967^{\circ} \mathrm{F}$.days. To comply with HERS and MEC 1993 standards using these degree-days, the following was required:

1. Glazing area $=18 \%$ of the floor area equally distributed on all four facades. This gives $84 \mathrm{ft}^{2}\left(7.8 \mathrm{~m}^{2}\right)$ of windows per side, with $27 \%$ of that area attributed to window frames.

2. The overall wall $\mathrm{U}$-value $=0.133 \mathrm{Btu} / \mathrm{hr} \cdot \mathrm{ft}^{2} \cdot{ }^{\circ} \mathrm{F}\left(0.757 \mathrm{~W} / \mathrm{m}^{2} \cdot \mathrm{K}\right)$. The specified opaque wall area $\mathrm{R}$-value is $17.2 \mathrm{hr} \cdot \mathrm{ft}^{2} \cdot{ }^{\circ} \mathrm{F} / \mathrm{Btu}\left(3.0 \mathrm{~m}^{2} \cdot \mathrm{K} / \mathrm{W}\right)$. As a result, windows have a U-value of $0.4 \mathrm{Btu} / \mathrm{hr} \cdot \mathrm{ft}^{2} \cdot{ }^{\circ} \mathrm{F}$ $\left(2.3 \mathrm{~W} / \mathrm{m}^{2} \cdot \mathrm{K}\right)$ for code compliance.

3. Roof R-value $=35.2 \mathrm{Btu} / \mathrm{hr} \cdot \mathrm{ft}^{2} \cdot{ }^{\circ} \mathrm{F}\left(6.2 \mathrm{~W} / \mathrm{m}^{2} \cdot \mathrm{K}\right)$.

4. Floor R-value $=4.5 \mathrm{hr} \cdot \mathrm{ft}^{2} \cdot{ }^{\circ} \mathrm{F} / \mathrm{Btu}\left(0.8 \mathrm{~m}^{2} \cdot \mathrm{K} / \mathrm{W}\right)$.

5. $\mathrm{ACH}=0.67$.

The house was assumed to have an HVAC system capable of meeting all heating and cooling requirements. Additional details on the HERS/MEC house development are available in Appendix C.

\subsection{Occupancy Assumptions}

The following values were chosen to reflect typical loads and thermostat settings in a residential space and are used for the base case as well as all the Tierra I models:

- The winter (September to April) heating set points are $65^{\circ} \mathrm{F}\left(18^{\circ} \mathrm{C}\right)$ from 10 p.m. to 5 a.m. and $70^{\circ} \mathrm{F}$ $\left(21^{\circ} \mathrm{C}\right)$ at all other times.

- The summer (May to August) heating set point is $60^{\circ} \mathrm{F}\left(16^{\circ} \mathrm{C}\right)$.

- The cooling set points are $83^{\circ} \mathrm{F}\left(28^{\circ} \mathrm{C}\right)$ for winter and $78^{\circ} \mathrm{F}\left(26^{\circ} \mathrm{C}\right)$ for summer.

- $\quad$ The venting set points are $79^{\circ} \mathrm{F}\left(26^{\circ} \mathrm{C}\right)$ for winter and $68^{\circ} \mathrm{F}\left(20^{\circ} \mathrm{C}\right)$ for summer.

- Internal gains are scheduled at $1.27 \mathrm{kBtu} / \mathrm{h}(372 \mathrm{~W})$ from 10 p.m. to 6 a.m. From 6 to 8 a.m. and from 6 to 10 p.m., internal gains are $4.24 \mathrm{kBtu} / \mathrm{h}(1243 \mathrm{~W})$. From 8 a.m. to 6 p.m. internal gains are $0.39 \mathrm{kBtu} / \mathrm{h}(114 \mathrm{~W})$.

Additional information on the development of the internal gain schedule is available in Appendix D. 


\subsection{Weather Data}

The simulation requires weather data that are representative of long-term average patterns at the site. Such weather data are available for Pueblo in TMY and TMY2 weather files. SUNREL can use either type, but for consistency with the STEM work, which required TMY files, the simulations used the TMY data set. A site-specific TMY file was developed by merging the weather data measured onsite with the Pueblo TMY file. The model calibration process uses this weather file to compare the as-built model against measured data over specific time periods.

The Tierra I site-measured weather data are consistent with the TMY weather data for Pueblo. Figure 9 shows average monthly global horizontal radiation for the TMY and local data. The Tierra average radiation levels for the year are only $4 \%$ lower than TMY levels. The average monthly temperatures are lower than the TMY temperatures in the first half of the year and higher in the second half. (See Figure 10.)

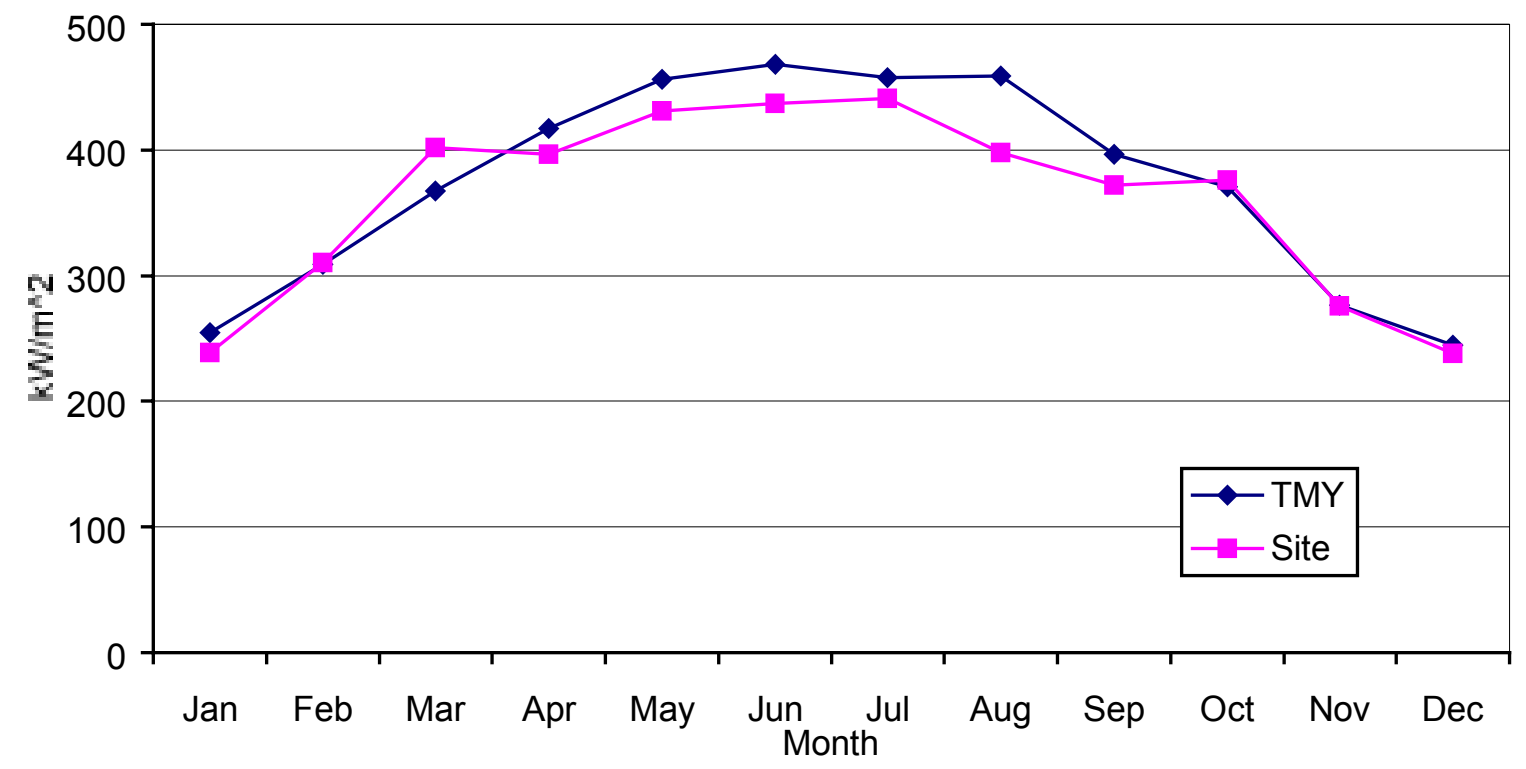

Figure 9. Average monthly global horizontal radiation 


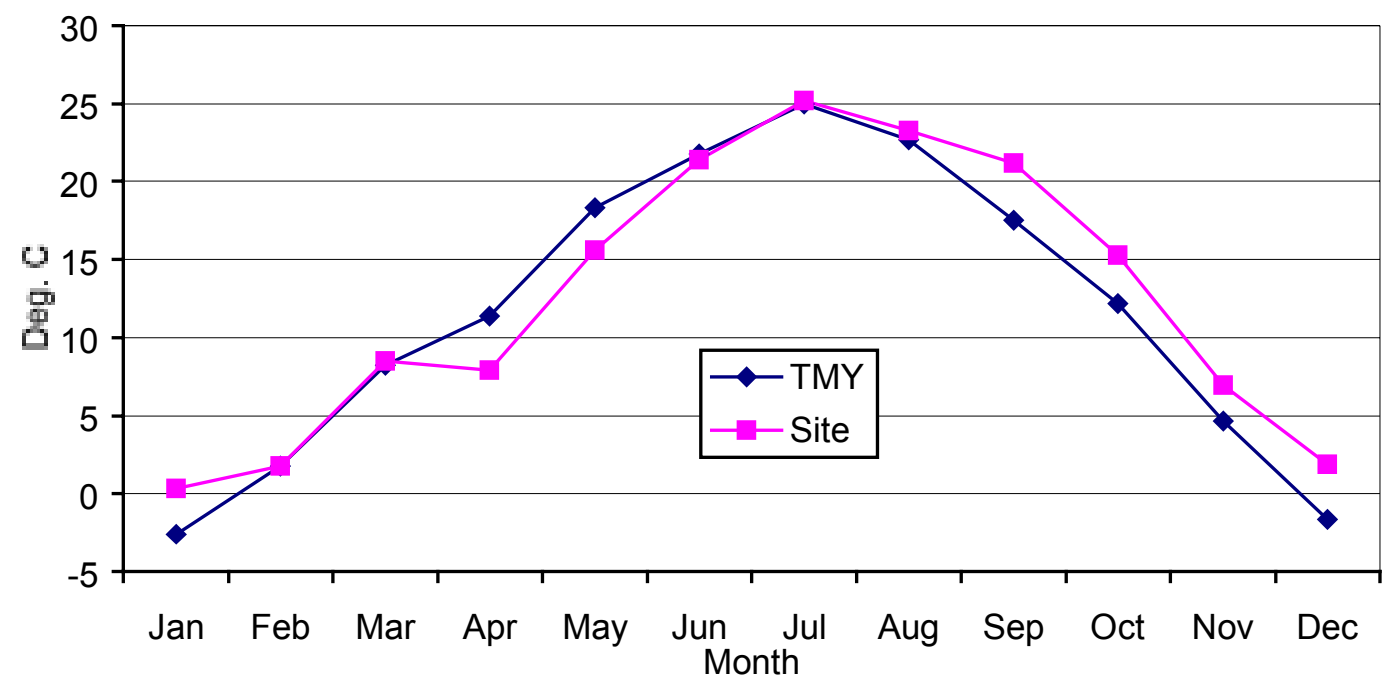

Figure 10. Average monthly outdoor temperature

\subsection{Base Case Results}

The base case heating load is $43.95 \mathrm{MMBtu} / \mathrm{year}(12.88 \mathrm{MW} \cdot \mathrm{hr} / \mathrm{year}$ ) and the cooling load is 6.85 MMBtu/year (2.01 MW·hr/year). The cooling loads of the base case are quite low because ventilation works well in the Pueblo climate to offset cooling requirements. The slab-on-grade construction also helps reduce the cooling loads by acting as a thermal sink.

\subsection{Tierra I Pre-Construction Model}

Construction plans were used to make the pre-construction model of Tierra I for the next step in the computer analysis. This required appropriate occupancy assumptions and annual weather information for the site. The simulation of Tierra I provided performance predictions of the house. These results were compared with the base case to gauge house performance.

\subsection{Results of the Thermal Analysis}

The pre-construction simulation of Tierra I predicted an annual energy use of 15.50 MMBtu (4.54 $\mathrm{MW} \cdot \mathrm{hr}) ; 14.87 \mathrm{MMBtu}(4.36 \mathrm{MW} \cdot \mathrm{hr})$ for heating, and 0.63 MMBtu (180 kW·hr) for cooling. This consumption level translates to roughly $\$ 93$ per year for heating and cooling calculated at a cost of $\$ 6 / \mathrm{MMBtu}$. The combined heating and cooling loads predicted by the pre-construction house are $69.5 \%$ lower than the base case loads (see Figure 11). Heating loads of the pre-construction model are $66 \%$ less than the base case while the cooling loads are $90 \%$ less, eliminating the need for mechanical cooling. 


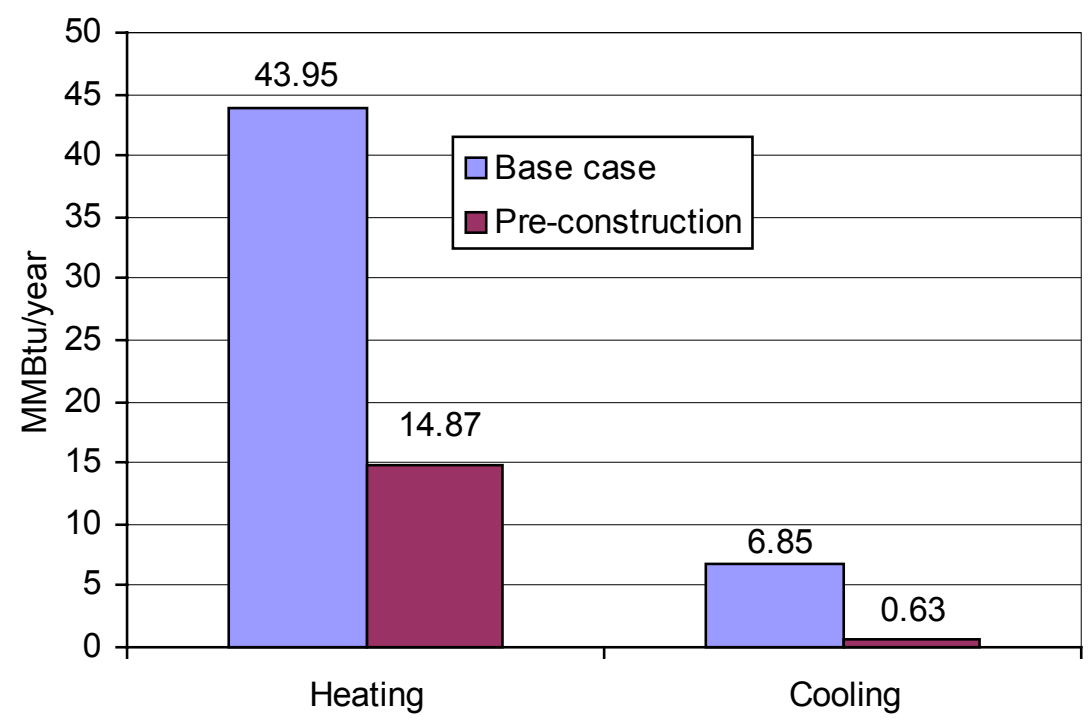

Figure 11. Base case and pre-construction model energy load comparison

\subsection{Model Calibration}

The pre-construction model provided a good preliminary assessment of the house performance. However, it needed to be updated after construction and then calibrated to the measured data. The post-construction model is called as-built and reflects changes between the pre-construction model and what was actually built. The main difference was in the glazing area. The as-built model has $7.6 \%$ less glazing than the preconstruction model.

To calibrate the as-built model, results were compared to data from two periods of the monitoring time frame. In the first period, November 23 through December 9, 1996, the house was heated with electric heaters used as part of the STEM testing. During the second period, January 1 to October 13, 1997, no heating, cooling, or ventilation was used, and there were minimal internal gains. The indoor temperatures were floating so the second period is labeled float. (See Table 4.)

Calibration adjusts various parameters until simulation results closely match measured data. Parameters were modified using STEM test results (see Chapter 4) as they indicate where the model is most likely under- or over-predicting. The STEM test indicated that the solar gains were only $73 \%$ of the model estimates. To account for the difference, the first modification to the model was to add artificial "screens" with a shading factor of 0.70 , chosen because that value eliminated the solar gain error when used in the STEM model.

The output of the calibrated model with just the "screen" modification sufficiently matched the measured data (See section 3.9) that no other modifications were deemed necessary.

\subsection{Calibrated and As-built Models Compared to Measured Data}

Tables 3 and 4 compare the calculated heating requirements for the as-built and calibrated models to the measured values. Each table also shows the average of the hourly root-mean-squared (RMS) temperature error between predicted and measured values. The measured temperature value is the average of all the inside temperature measurements. 
Table 3. Heat Period-November 23-December 9, 1996

\begin{tabular}{|l|r|r|r|}
\hline \multicolumn{1}{|c|}{ Case } & $\begin{array}{c}\text { Total Energy } \\
(\mathrm{KBtu})\end{array}$ & \multicolumn{1}{c|}{ Error } & $\begin{array}{c}\text { Temperature RMS } \\
\text { Error }\left({ }^{\circ} \mathrm{F}\right)\end{array}$ \\
\hline Measured & 4368.0 & & \\
\hline As-built & 3040.8 & $-30.4 \%$ & 2.4 \\
\hline Calibrated & 3734.2 & $-14.5 \%$ & 1.0 \\
\hline
\end{tabular}

Table 4. Float Period-January 1-October 13, 1997

\begin{tabular}{|l|r|r|r|}
\hline \multicolumn{1}{|c|}{ Case } & $\begin{array}{c}\text { Total Energy } \\
(\mathrm{kBtu})\end{array}$ & \multicolumn{1}{c|}{ Error } & $\begin{array}{c}\text { Temperature RMS } \\
\text { Error }\left({ }^{\circ} \mathrm{F}\right)\end{array}$ \\
\hline Measured & 5748.0 & & 3.8 \\
\hline As-built & 5753.7 & $0.1 \%$ & 3.2 \\
\hline Calibrated & 5753.7 & $0.1 \%$ & \\
\hline
\end{tabular}

Table 5 shows the monthly temperature RMS error for the float period. The calibrated model error is less than $2.53{ }^{\circ} \mathrm{F}\left(1.41^{\circ} \mathrm{C}\right)$ for all but three months; January, February, and April. These months may have a larger error because snow may have changed ground reflectivity that was not measured by the horizontally mounted pyranometer. The incorrect radiation measurements, in turn, affected the modeling results.

Appendix $\mathrm{H}$ contains monthly graphs of the measured indoor temperature and the as-built and calibrated model temperature predictions as well as graphs showing rain and snowfall for each month. The as-built model tends to over-predict the temperature, while the calibrated model tends to under-predict . Based on these temperature trends, it seems likely that the actual annual heating load would fall somewhere between what the as-built and calibrated model predict.

Table 5. Coast Period Monthly Temperature Error

\begin{tabular}{|l|l|l|}
\hline & As-built $\left({ }^{\circ} \mathrm{F}\right)$ & Calibrated $\left({ }^{\circ} \mathrm{F}\right)$ \\
\hline Total RMS & 3.81 & 3.22 \\
\hline Jan & 3.14 & 5.81 \\
\hline Feb & 2.96 & 5.88 \\
\hline Mar & 6.77 & 2.53 \\
\hline Apr & 4.04 & 3.30 \\
\hline May & 2.89 & 1.14 \\
\hline Jun & 3.53 & 1.78 \\
\hline Jul & 4.02 & 2.25 \\
\hline Aug & 1.97 & 1.14 \\
\hline Sep & 2.57 & 1.48 \\
\hline Oct & 4.26 & 1.35 \\
\hline
\end{tabular}

\subsection{Analysis of the Calibrated Model}

The calibrated model predicts a heating load of 22.40 MMBtu (6.57 MW.hr) and a cooling load of 0.04 MMBtu (11.7 kW·hr) annually. This is a 56\% savings compared to the base case, which is less than the 
$70 \%$ goal. A look at the segregated heat loss (See Figure 12) shows ground heat loss is the most significant followed by window and wall heat loss. Figure 13 shows that passive solar provides $50 \%$ of the required heating.

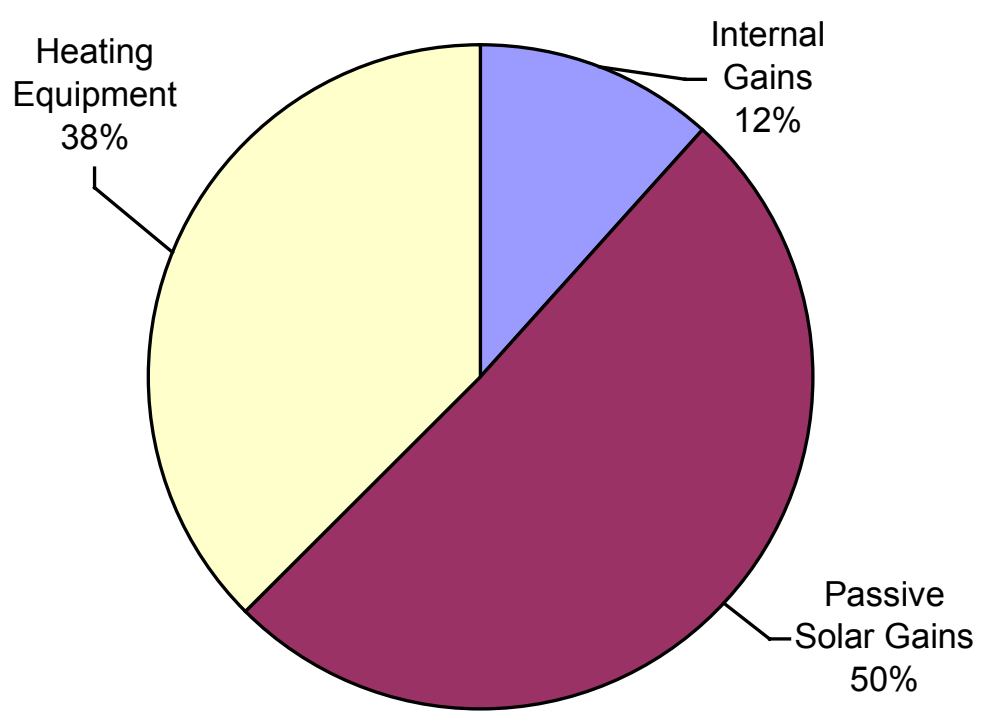

Figure 12. Segregated heat loss for calibrated model

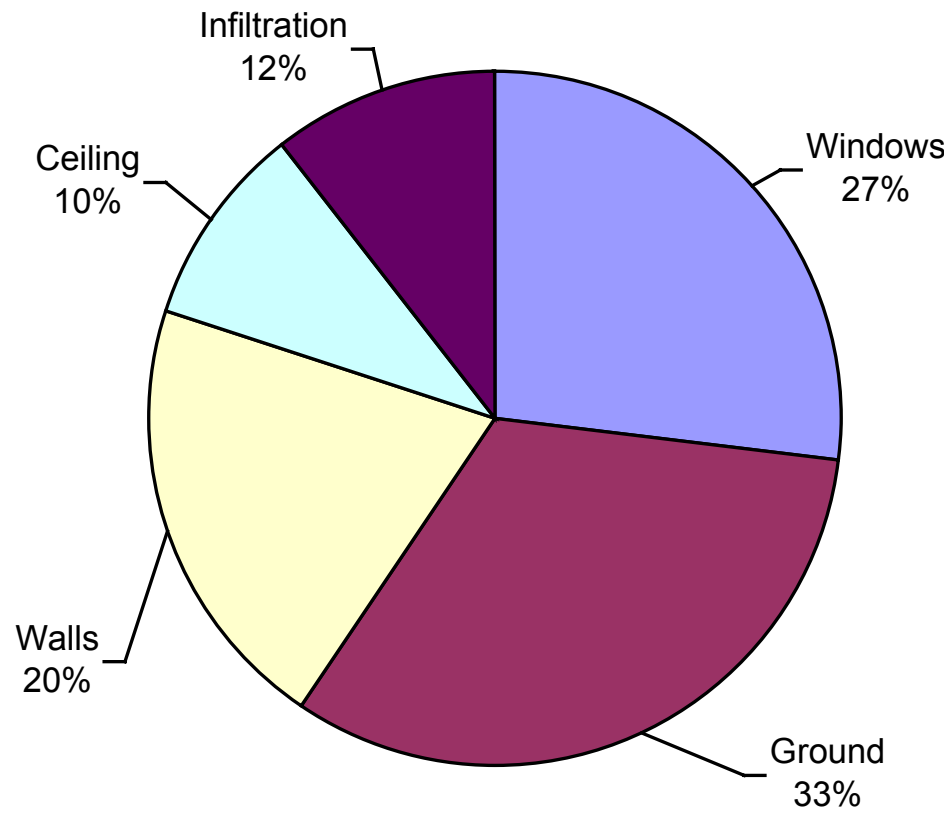

Figure 13. Breakdown of heat sources 


\section{CHAPTER 4 - Data Collection and Analysis}

\subsection{Data Monitoring Setup}

Tierra I was monitored to validate simulations and evaluate its energy performance. Long-term datameasuring points inside the house and collecting outdoor weather and solar radiation information-was collected for over a year (see section 4.8.). Short-term data were collected for the STEM test over a period of a few weeks. (See section 4.4.)

\subsection{Long-Term Data Collection}

A data monitoring system was installed on July 22, 1996. The system used 17 channels to collect data in hourly increments. The setup was not complete until November 18, when the number of channels was increased to 19. Two channels were added for diagnostic information about the data recorder. Several other channels that had not been operating correctly were fixed. Monitoring continued until October 14, 1997, when the system was removed.

The monitoring system consisted of a Campbell Scientific CR-10X data recorder connected to a modem for remotely downloading data. The system installation included the following instrumentation:

1. Type $\mathrm{T}$ thermocouples to measure temperature within $\pm 0.5^{\circ} \mathrm{F}\left( \pm 0.28^{\circ} \mathrm{C}\right)$.

2. A Hall-effect watt-transducer to measure electric power within $\pm 0.5 \%$ [11].

3. A Li-Cor Li200 pyranometer to measure solar irradiance within of $\pm 3 \%$ [12].

4. RH sensor accurate to $\pm 2 \%$ at $10 \% \mathrm{RH}$ and $\pm 3 \%$ at $90 \% \mathrm{RH}[13]$.

5. RMYoung wind speed and direction sensor [14].

Table 6 lists the data record, which is a comma-delimited file with a one-line header. The channels are scanned every 5 seconds, averaged, and stored hourly. Appendix G contains the data logger program and a sample data record.

Table 6. Long-Term Data Acquisition Channels

\begin{tabular}{|l|l|l|l|}
\hline Channel & Designation & Units & Comment \\
\hline 1 & Log ID & N/A & Data logger identification information \\
\hline 2 & Year & YYYY & \\
\hline 3 & Day & XXX & 1 = Jan. 1st etc. (Day Of Year) \\
\hline 4 & Hour & Hours & 0 to 2300 \\
\hline 5 & TCcsfam & ${ }^{\circ} \mathrm{C}$ & Black copper sphere (radiant temp.) family room \\
\hline 6 & TCfam & ${ }^{\circ} \mathrm{C}$ & Thermocouple, family room \\
\hline 7 & TCsmbed & ${ }^{\circ} \mathrm{C}$ & Black copper sphere (radiant temp.), master bed \\
\hline 8 & TCmbed & ${ }^{\circ} \mathrm{C}$ & Thermocouple, master bedroom \\
\hline 9 & TCbat & ${ }^{\circ} \mathrm{C}$ & Thermocouple, outside bathroom \\
\hline 10 & TCbed & ${ }^{\circ} \mathrm{C}$ & Thermocouple, bedroom \\
\hline 11 & TCdryer & Boolean & Dryer on/off \\
\hline 12 & Solar_Rad & W/m & Global horizontal solar radiation \\
\hline 13 & RHoutside & $\%$ & Outside relative humidity \\
\hline 14 & TCoutside & ${ }^{\circ} \mathrm{C}$ & Outside dry-bulb temperature \\
\hline
\end{tabular}




\begin{tabular}{|l|l|l|l|}
\hline 15 & Wind_SP & Mph & Wind velocity - mile per hour \\
\hline 16 & Wind_Dir & Deg & Wind direction - degree \\
\hline 17 & Total_Power & W & Total house electric power - watts \\
\hline 18 & Tref & ${ }^{\circ} \mathrm{C}$ & Datalogger temperature (used for diagnostics) \\
\hline 19 & Batt_V & V & Datalogger battery voltage (used for diagnostics) \\
\hline
\end{tabular}

\subsection{Short-Term Data Collection}

Short-term data (see Table 7) for the STEM test procedure were collected from November 19 to December 10, 1996, using a separate data logger from the one used for long-term data. Only indoor information was logged with the short-term monitoring equipment. All outdoor data needed for the STEM test is taken from the long-term data collection.

Table 7. Short-Term Data Acquisition Channels

\begin{tabular}{|l|l|l|l|}
\hline Channel & Designation & Units & Comment \\
\hline 1 & Log ID & N/A & Data Logger identification information \\
\hline 2 & Year & YYYY & \\
\hline 3 & Day & XXX & 1 = Jan. 1st etc. (Day Of Year) \\
\hline 4 & Hour & Hours & 0 to 2300 \\
\hline 5 & T1 & ${ }^{\circ} \mathrm{C}$ & Located in master bedroom \\
\hline 6 & T2 & ${ }^{\circ} \mathrm{C}$ & Located in bedroom \\
\hline 7 & T3 & ${ }^{\circ} \mathrm{C}$ & Located in bedroom \\
\hline 8 & T4 & ${ }^{\circ} \mathrm{C}$ & Located in dining room \\
\hline 9 & T5 & ${ }^{\circ} \mathrm{C}$ & Located in kitchen \\
\hline 10 & T6 & ${ }^{\circ} \mathrm{C}$ & Located in living room \\
\hline 11 & H1 & $\%$ & Fraction of hour electric heater \# 1 was on \\
\hline 12 & H2 & $\%$ & Fraction of hour electric heater \# 2 was on \\
\hline 13 & H3 & $\%$ & Fraction of hour electric heater \# 3 was on \\
\hline 14 & H4 & $\%$ & Fraction of hour electric heater \# 4 was on \\
\hline 15 & H5 & $\%$ & Fraction of hour electric heater \# 5 was on \\
\hline 16 & H6 & $\%$ & Fraction of hour electric heater \# 6 was on \\
\hline 17 & TSet & ${ }^{\circ} \mathrm{C}$ & Temperature set point for heating \\
\hline 18 & Tref & ${ }^{\circ} \mathrm{C}$ & Datalogger temperature (used for diagnostics) \\
\hline 19 & Batt V & V & Datalogger battery voltage (used for diagnostics) \\
\hline
\end{tabular}

\subsection{STEM Test}

STEM tests provide an additional method of analyzing a house's performance. The STEM test is used to obtain the thermal parameters of a building, which can be used for long-term extrapolation [15]. The STEM method consists of two key elements: the test protocol and the analysis method. The protocol is designed to generate steady-state and transient data sequences that fit the requirements of the analysis method. The analysis method used in the STEM test for Tierra I is called primary- and secondary-term analysis and re-normalization (PSTAR), which provides a formal approach to the separation of cause and effect in the data [16].

Data for the STEM test are collected while the house is unoccupied to eliminate uncertainties caused by occupant behaviors. A typical STEM test requires only a few days, but because Tierra I was unoccupied, the data collection lasted several weeks. STEM test data were analyzed using the STEM 2.0 software 
[17], which automates the analysis procedure. The software limited the number of analysis days to six. The data from November 25-30, 1996, were used because those data contained the necessary data sequences.

\subsection{STEM Test Procedure}

First, a one-time air pressurization and depressurization test was done using a blower door. The blower door test determined the building's effective leakage area (ELA). To perform this test, the doors, windows, and other openings in the house were closed, and a fan was used to pressurize the house (see Figure 14). The airflow rate was measured along with the inside-to-outside pressure difference. The ELA was estimated from a power-law curve fit of pressure difference plotted versus airflow rate (see Figure 17). It can be used to estimate infiltration based on stack and wind driving forces [18].

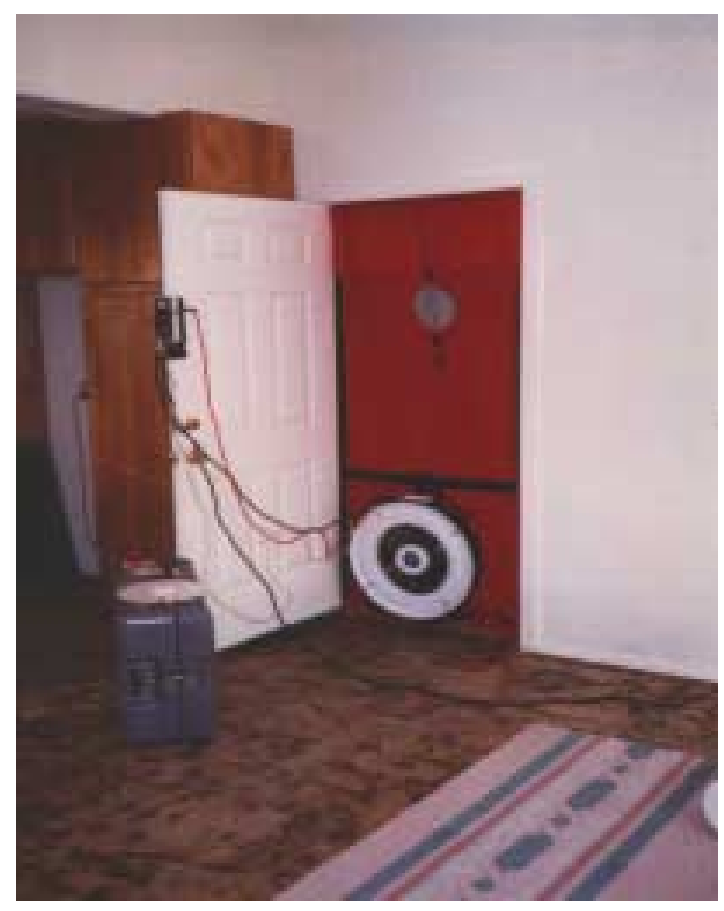

\section{Figure 14. Blower door test setup}

Next, a temporary data-acquisition system was installed and programmed with the test protocol to collect data. The protocol specifies a series of conditions controlled by turning electric resistance heaters on and off. The objective was to obtain data near a steady-state condition during the first night or nights (called the "co-heat" period) by maintaining a minimum indoor temperature using the heaters. The test procedure also specified cold outside temperatures. On subsequent nights, a cool-down period was initiated by turning the heaters off at midnight and recording the resulting temperature drops. Daytime data were used to determine the effect of solar gains. During the entire test, all house appliances and lights were turned off to reduce uncertainties $[15,18]$.

\subsection{STEM Software}

The STEM 2.0 software incorporates the multi-zone PSTAR method to analyze the data and automate the process [19]. This method is based on an hourly dynamic energy balance equation for the house. The STEM 2.0 software uses a specially adapted SERI-RES audit model of the house as part of the input. 
A second set of input is derived from the collected data. The methodology used by STEM 2.0 as well as the STEM procedure and the PSTAR method are described more fully in Appendix A.

\subsection{STEM Output}

The STEM testing produces several results. The first is the ELA determined by the blower door test. The other results are obtained from the STEM 2.0 software, which gives a renormalizing factor to three primary heat flows. The STEM software also plots the audit, renormalized, and measured indoor temperatures and heating loads (see Figures 15 and 16).

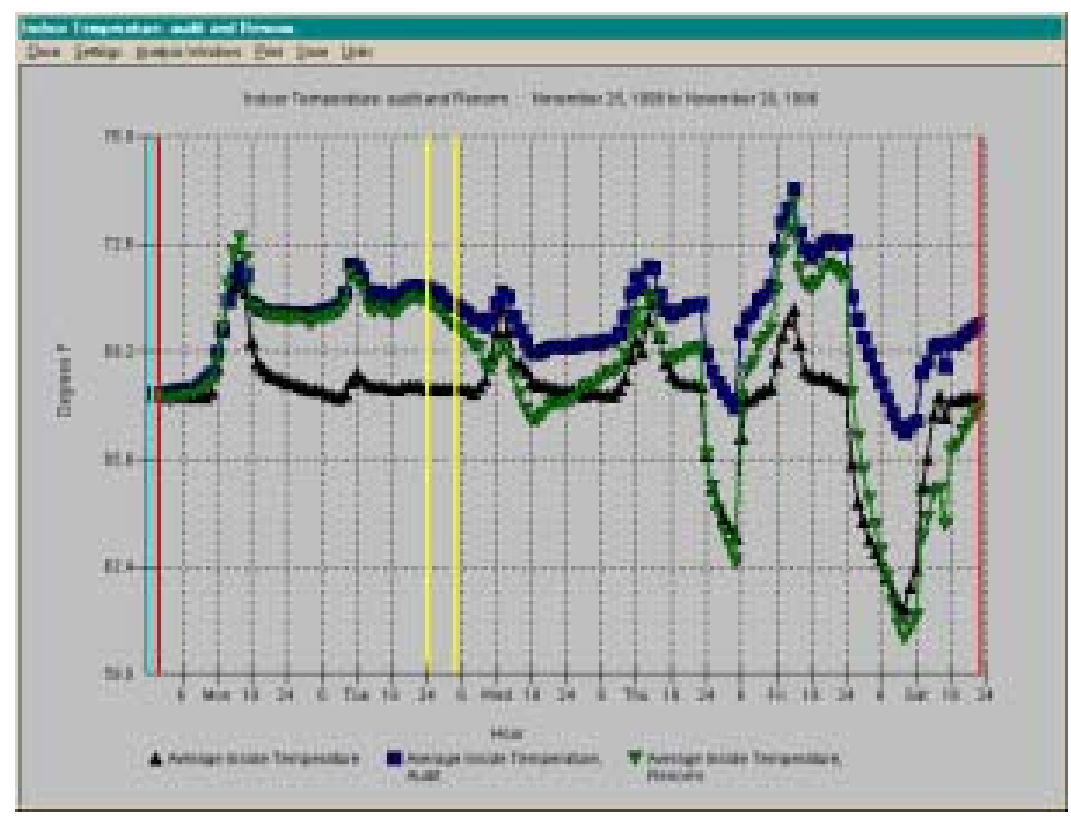

Figure 15. STEM inside temperature graph

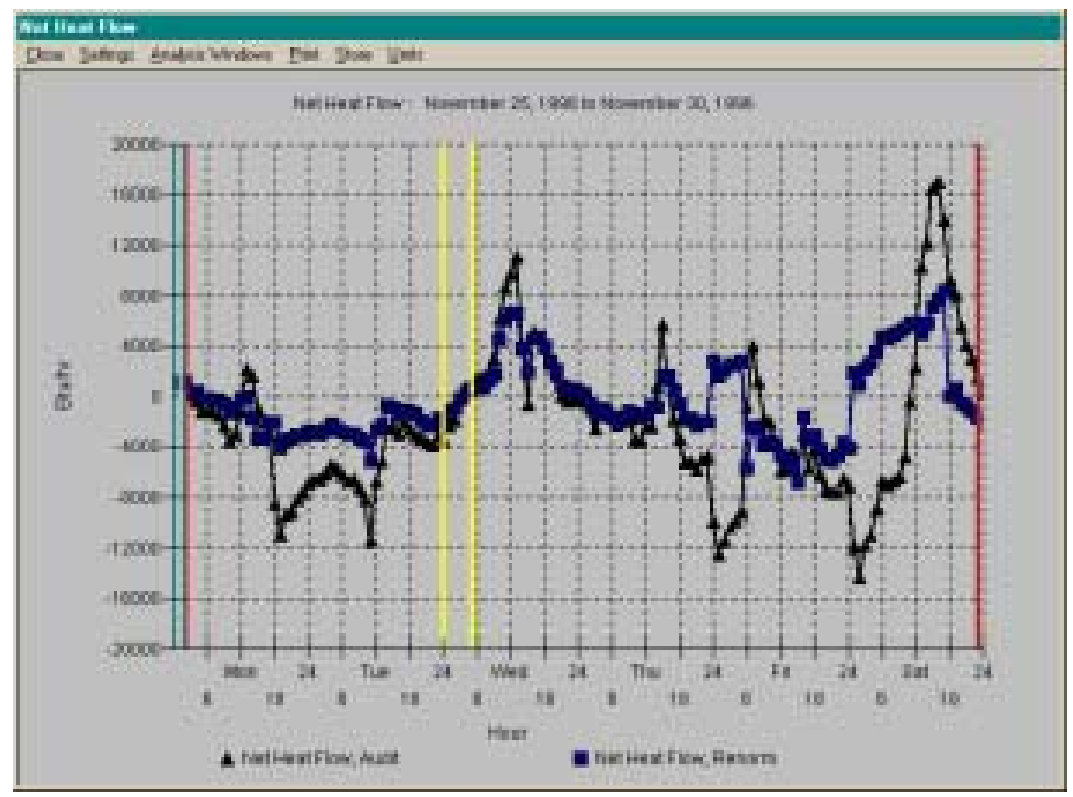

Figure 16. STEM heat flow graph 
The blower door test showed the ELA to be $62 \mathrm{in}^{2}$ using the power-law curve fit of pressure difference versus air-flow (see Figure 17). The corresponding ACH level (derived in Appendix J) is $0.2 \mathrm{ACH}$. The low ELA and ACH means that the infiltration term is not a significant source of error in the PSTAR process used in the STEM 2.0 software.

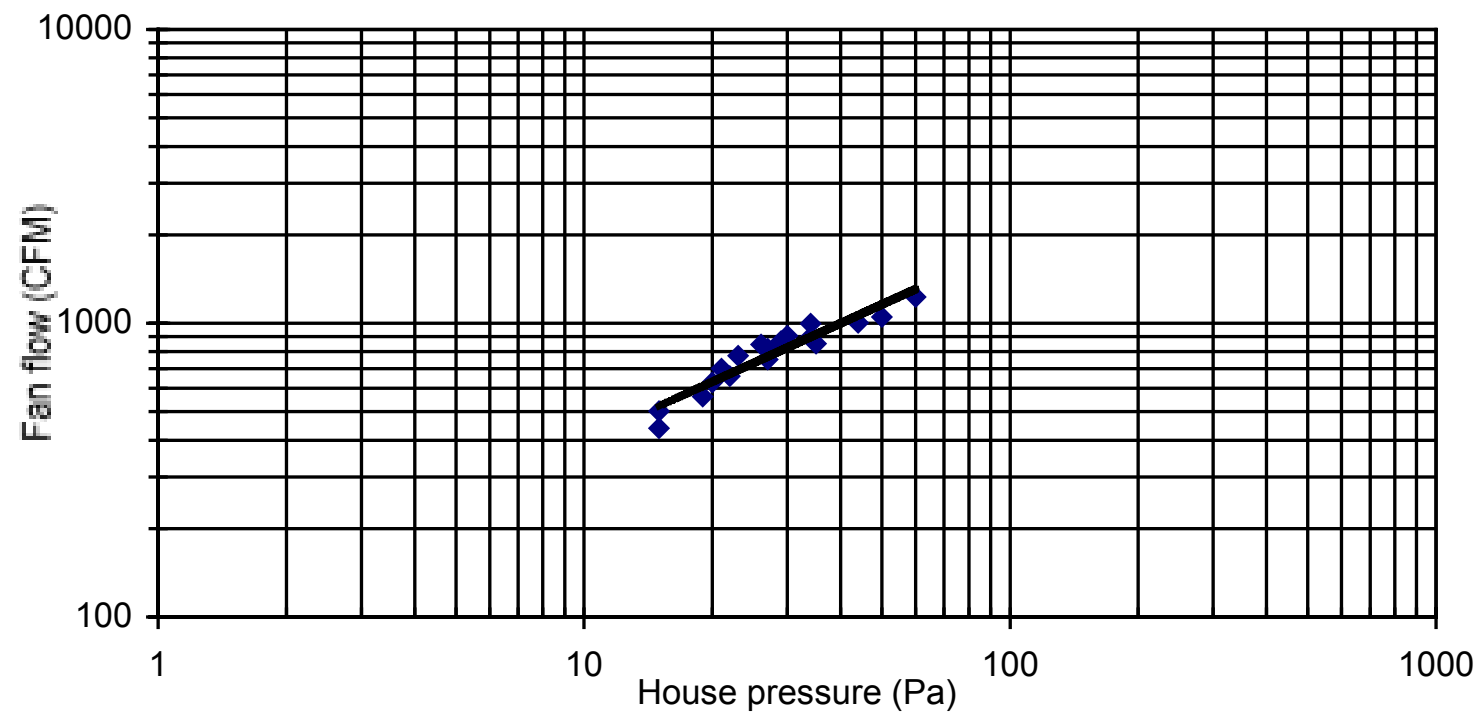

Figure 17. ELA power law curve fit

The first primary heat flow renormalized by the STEM 2.0 program was the building conductive gain to room air from outside air under measured under steady-state conditions, which is calculated as building load coefficients (BLC) times the inside-outside temperature difference. Renormalizing is accomplished by multiplying the heat flow by a weighting factor, which results from using the PSTAR method $[15,16,18]$. The preliminary BLC obtained from the building envelope properties of the as-built model was $496 \mathrm{Btu} / \mathrm{hr} \cdot{ }^{\circ} \mathrm{F}\left(261 \mathrm{~W} /{ }^{\circ} \mathrm{C}\right)$ including $46 \mathrm{Btu} / \mathrm{hr} \cdot{ }^{\circ} \mathrm{F}\left(24 \mathrm{~W} /{ }^{\circ} \mathrm{C}\right)$ caused by infiltration. This compares to $357 \mathrm{Btu} / \mathrm{h} \cdot{ }^{\circ} \mathrm{F}\left(203 \mathrm{~W} /{ }^{\circ} \mathrm{C}\right)$ when calculated manually, without including infiltration, as shown in Appendix E. The renormalizing factor was 0.99 , resulting in an adjusted $\mathrm{BLC}$ of $446 \mathrm{Btu} / \mathrm{h} \cdot{ }^{\circ} \mathrm{F}\left(235 \mathrm{~W} /{ }^{\circ} \mathrm{C}\right)$, not including the infiltration.

The second primary term renormalized is the heat flow to the room air that results from changes in inside air temperatures, which relates to the effective capacity of the house to store heat. The value predicted from the audit model was adjusted by a factor of 0.40 , resulting in an effective building heat capacity of $113,651 \mathrm{Btu} /{ }^{\circ} \mathrm{F}\left(215,824 \mathrm{~kJ} /{ }^{\circ} \mathrm{C}\right)$.

The last term renormalized was the heat flow to the inside air caused by solar gain. This heat flow refers to solar gains through windows, heat stored in building mass that gets discharged into the inside air and heat flow through external walls caused by solar absorption. This effective solar gain was shown to be $73 \%$ of the value predicted by the audit model.

\subsection{Long-Term Data Analysis}

Even though the data logger was installed earlier, complete sets of continuous long-term data are only available from November 18, 1996, through October 14, 1997, because of data collection problems. During this period, the house was unoccupied. Heating was provided only during the STEM testing 
period, which prevents proper comparison with STEM results or with long-term predictions of the computer models. Additionally there was no natural ventilation, which is an integral part of the house's cooling energy performance. However, the data are useful for observing the temperature stabilizing performance of the building as seen in Figure 18, which shows the hourly indoor and outdoor temperatures from November 1996 to October 1997.

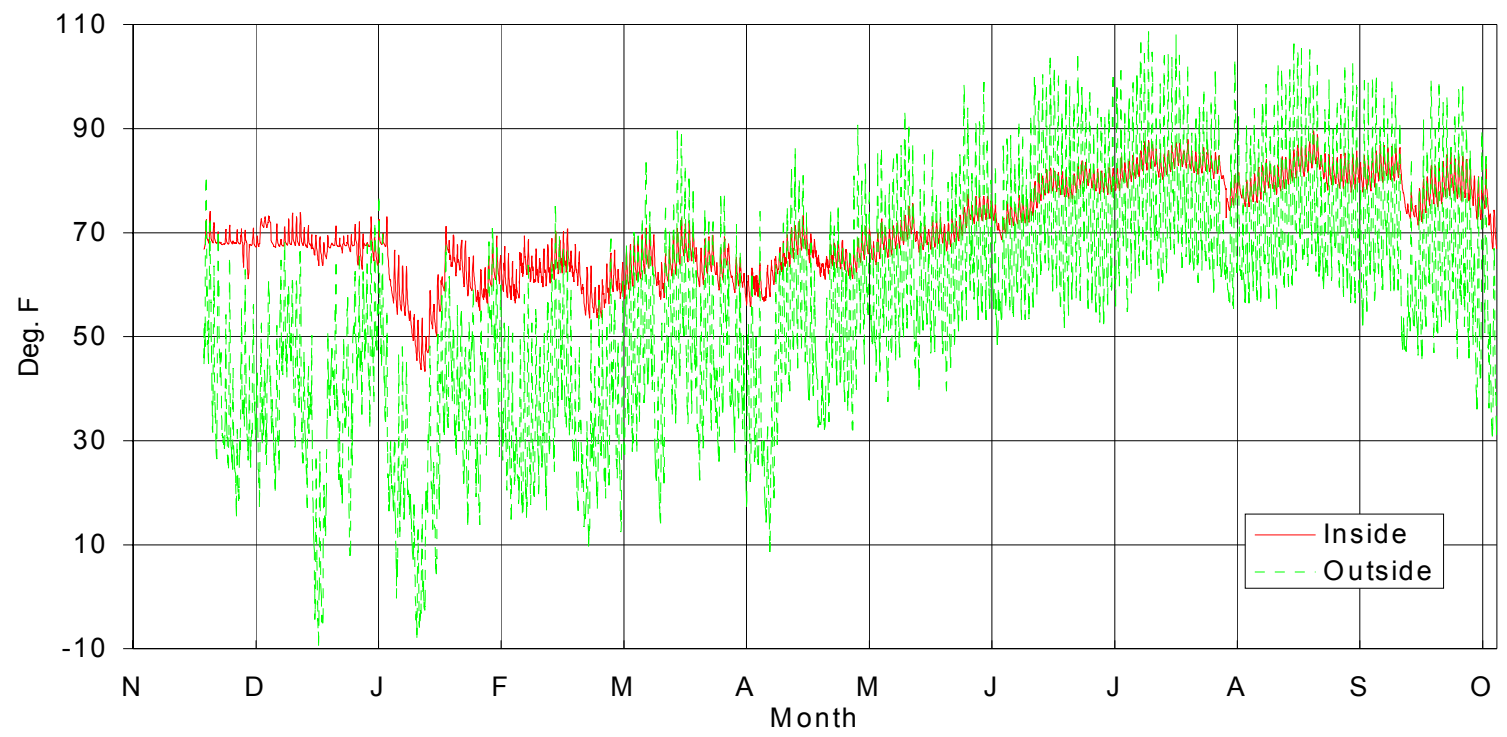

Figure 18. November to October indoor and outdoor temperature profiles

Figure 19 shows the January temperature profile when the coldest indoor temperatures occur. The temperature never drops below $40^{\circ} \mathrm{F}\left(4.4^{\circ} \mathrm{C}\right)$ even though outdoor temperatures were below freezing for a large part of the month, including several sub-zero $\left(-18^{\circ} \mathrm{C}\right)$ days. These temperatures were maintained without any heating or significant internal gains, indicating that the temperature inside the house is unlikely to ever drop below freezing. This makes the passive solar design very resistant to disasters where infrastructure is disabled.

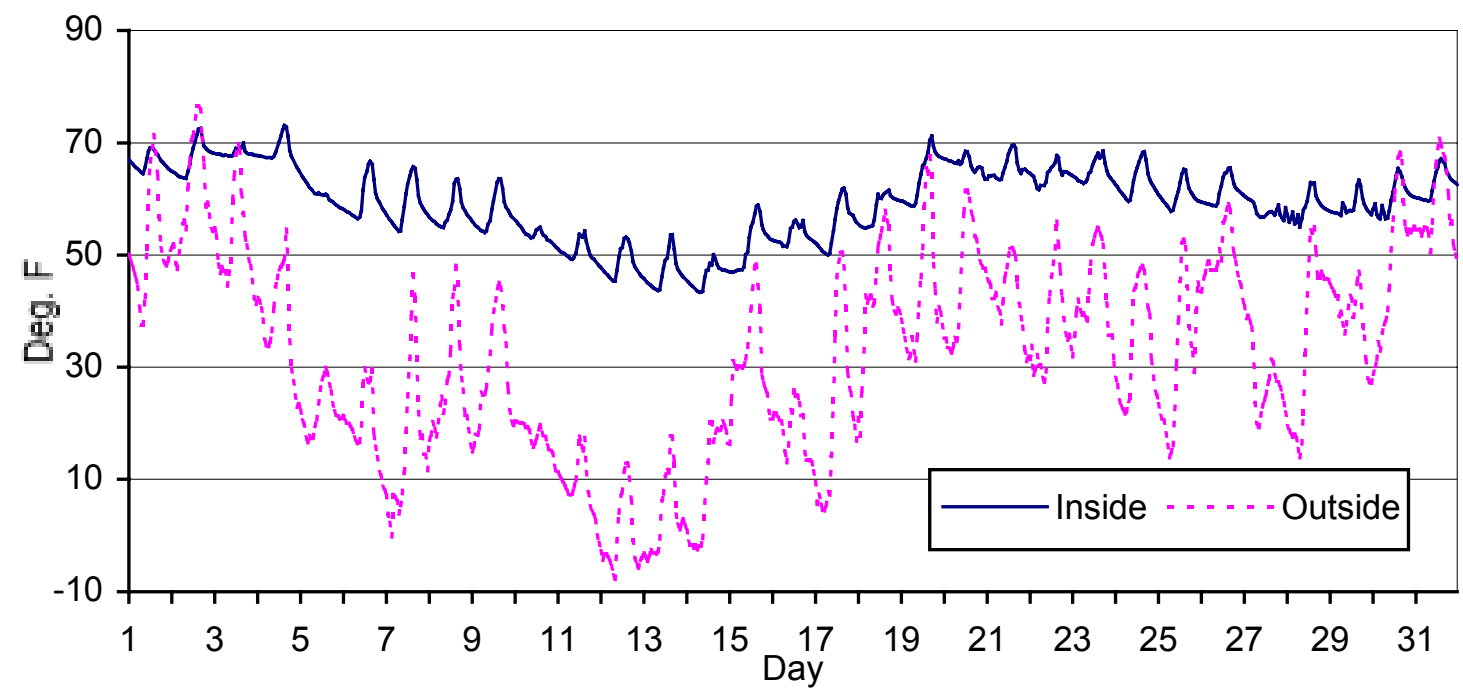

Figure 19. January hourly inside and outside temperatures 
The ability of the house to stay cool without air-conditioning is only partly evident from the long-term data. During July, the house maintained an $80^{\circ}-85^{\circ} \mathrm{F}\left(26.7^{\circ}-29.4^{\circ} \mathrm{C}\right)$ indoor temperature range with outside temperatures of more than $100^{\circ} \mathrm{F}\left(37.8^{\circ} \mathrm{C}\right)$ (see Figure 20). This range is above the acceptable ASHRAE comfort range [20] by only a few degrees. Because there were no occupants during the monitoring period, natural ventilation did not occur. The low nightly temperatures indicate that the house could benefit from venting. The house is designed to get its cooling from the night venting, which would reduce the internal temperatures to an acceptable level. Simulation results using the calibrated model with proper venting show that the house would remain below $78^{\circ} \mathrm{F}$ (within the comfort range for this climate) during July, the hottest month of the year (see Figure 21). Cooling loads are insignificant and with good design, air-conditioning is not necessary to maintain thermal comfort in this climate.

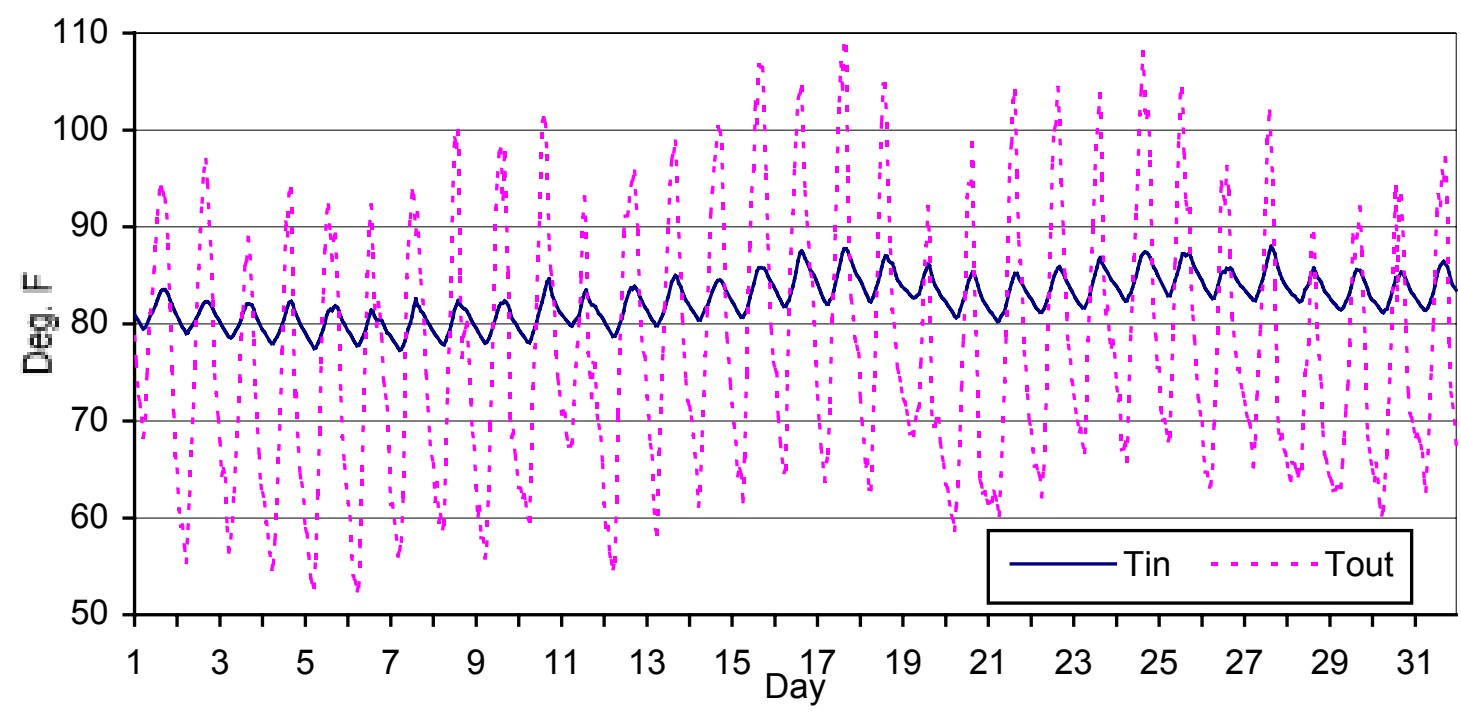

Figure 20. July temperature profiles 


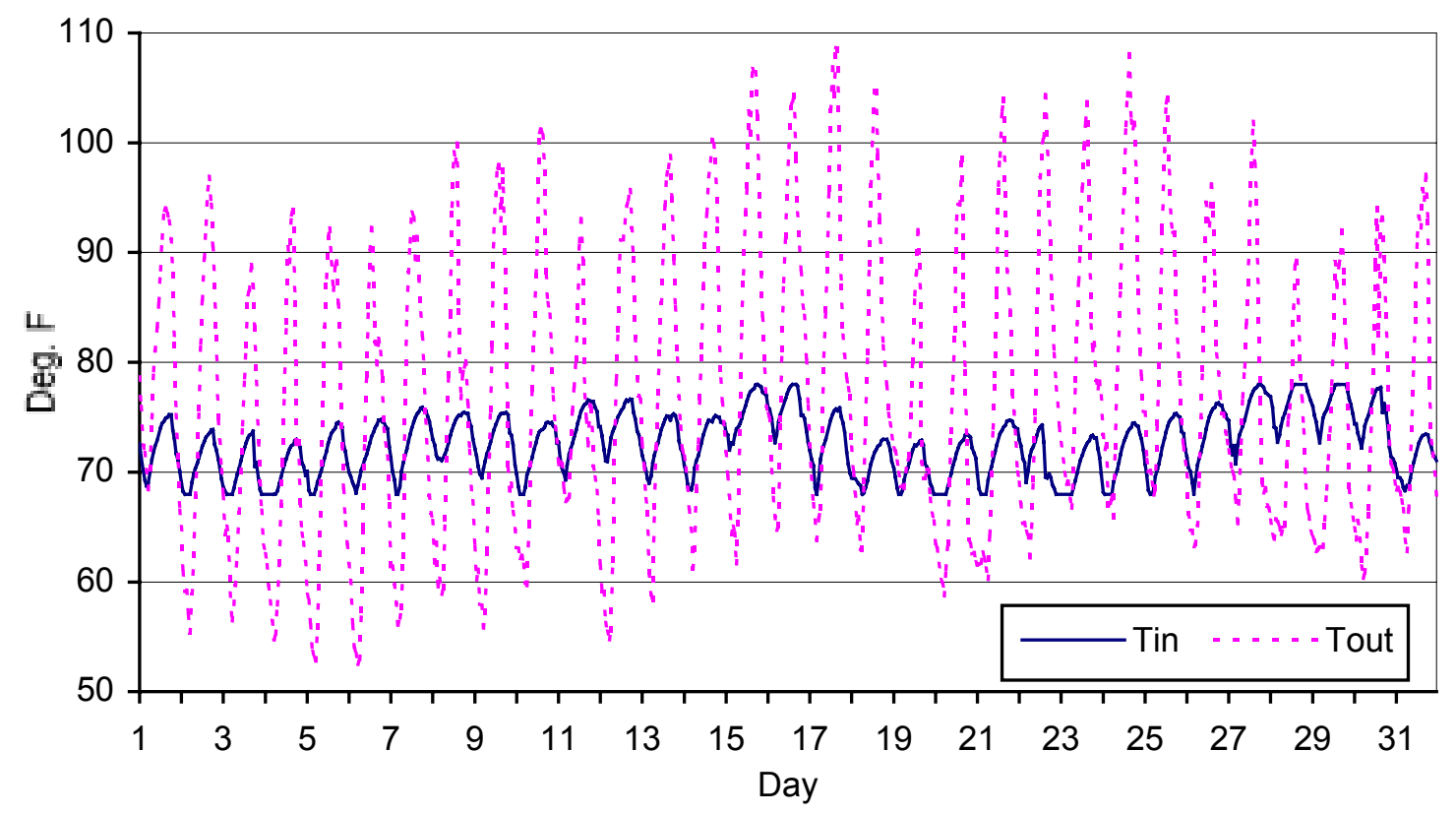

Figure 21. Predicted indoor temperatures with night venting

Figures 22 and 23 show the individual indoor temperature channels plotted together for January and July. There are slight variations in temperature throughout the house. The data show that the heat from solar gains is well distributed with no single room displaying a tendency to heat up more than another. This indicates that the natural convection does a good job of mixing the air in the house.

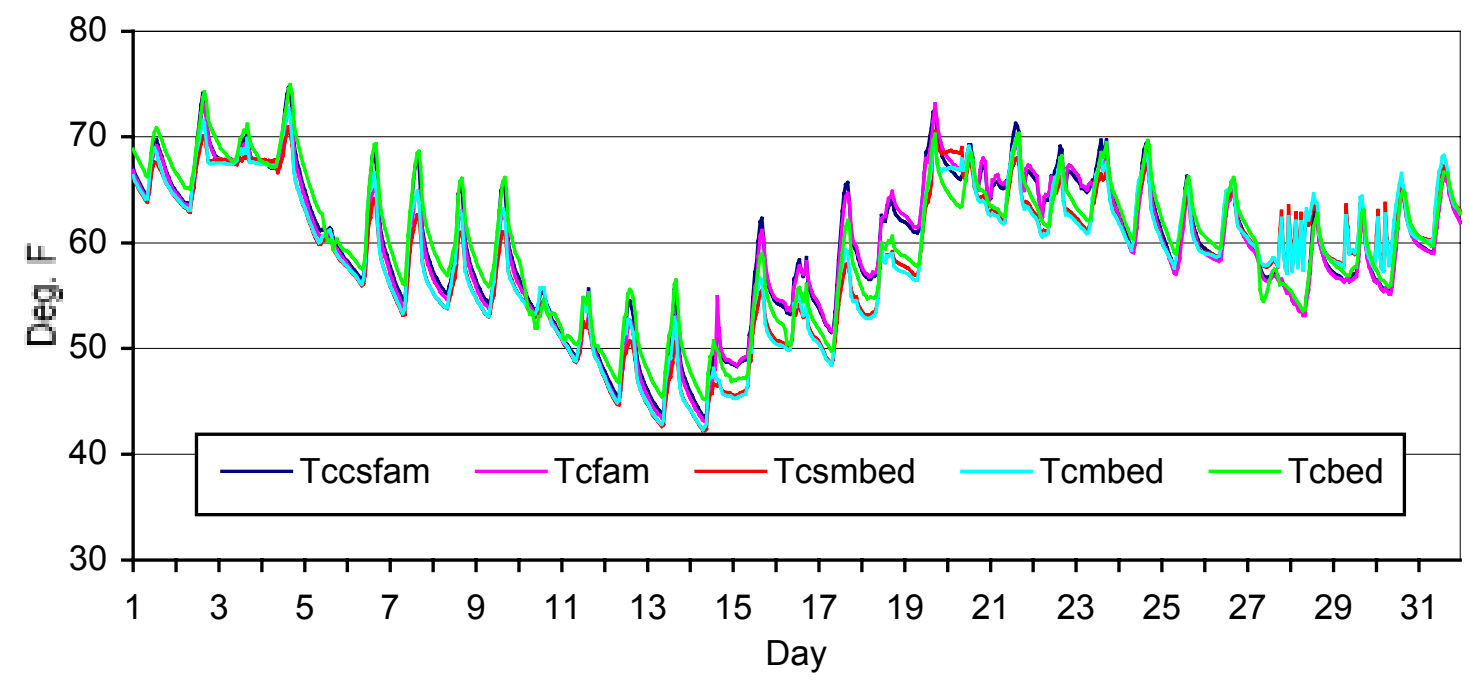

Figure 22. Individual indoor temperature profiles for January 


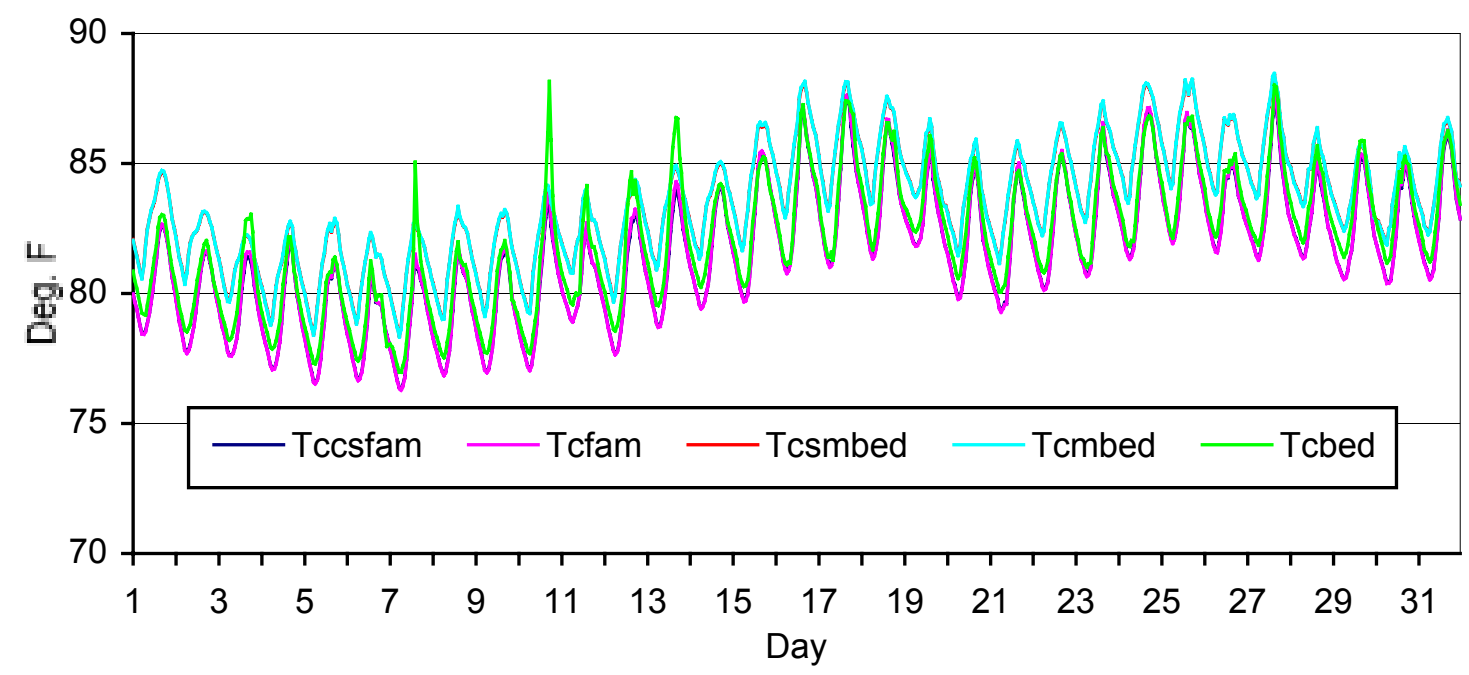

Figure 23. Individual indoor temperature profiles for July

Researchers anticipated that the house would be sold, and that long-term data could be used to study the occupant interaction with the low-energy home. The house was on the market for the entire time data was being collected. When the house finally sold, the owners did not want data collection to continue.

\subsection{Infrared Analysis}

Infrared imaging identifies problem areas in the building envelope such as insufficient insulation levels or thermal bridging by measuring surface temperatures. Cooler surfaces show up as greens and blues, and warmer surfaces show up in reds and yellows. Infrared pictures of the inside and outside of Tierra I were taken to identify areas of poor thermal performance.

According to the infrared images, the roof insulation appears adequate (see Figures 24 and 25) because the roof shows up as cool (light blue). The walls appear much warmer (red and orange), indicating the insulation levels are not as good. This is especially evident in Figure 26 and backs up the STEM conclusions that the BLC is too low in the as-built model. These observations agree with the results of the calibrated model, which indicate a high level of heat loss from the walls compared to the loss from the ceiling.

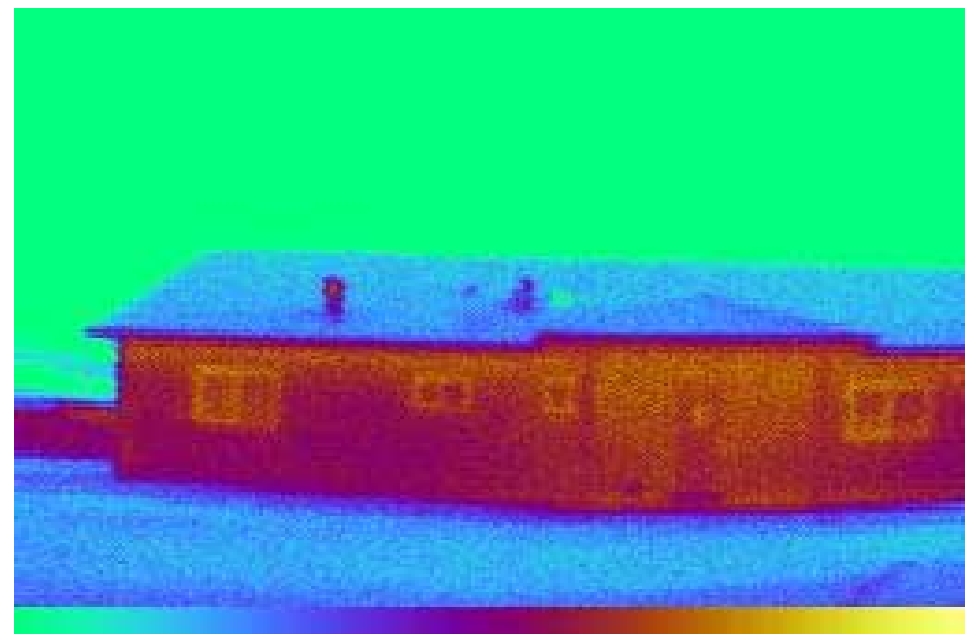

Figure 24. Infrared image of north side of house 


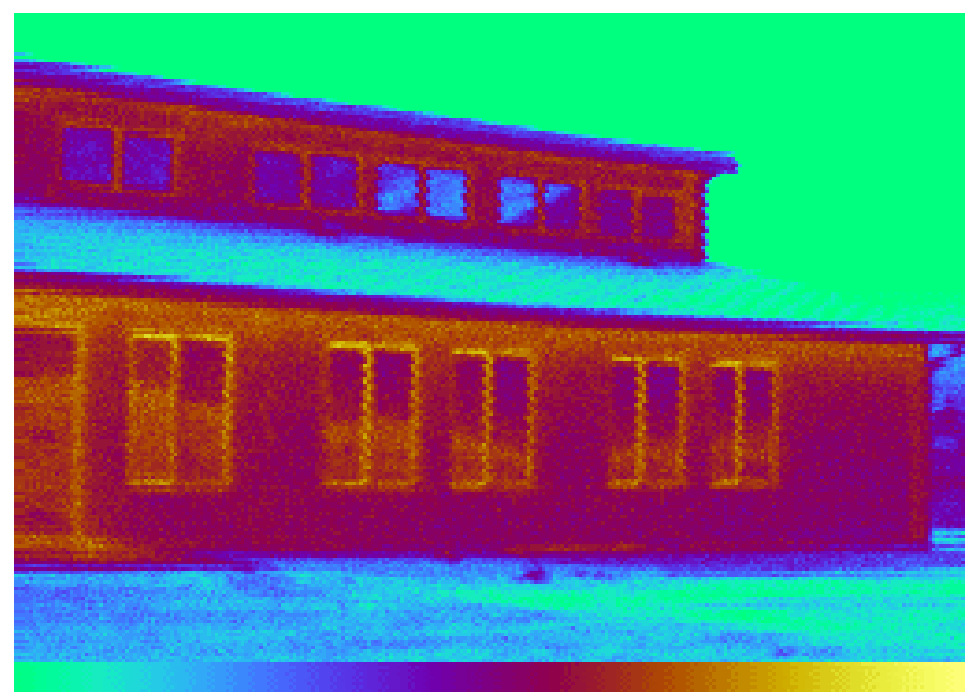

Figure 25. Infrared image of south side of house

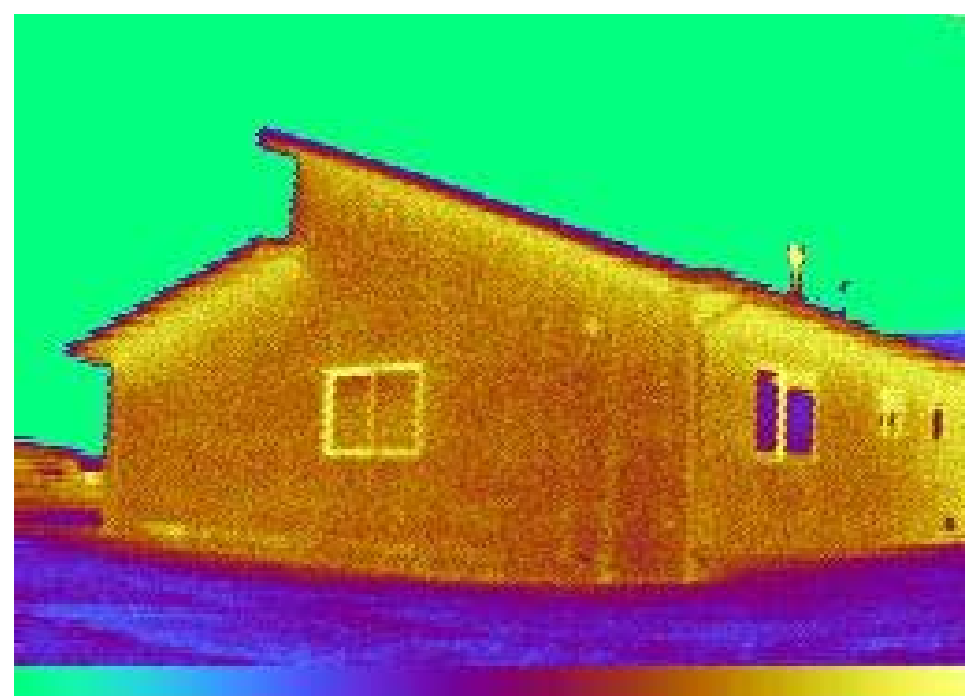

\section{Figure 26. Infrared image of east side of the house}

On the inside of the house, infrared images showed some thermal bridging in the ceilings where the rafters are located. The thermal bridges show up as cool (blue) streaks in the ceiling (see Figure 27). Poor thermal performance in the corners and along the edges where the walls and ceiling meet is also evident as indicated by very cool (green) patches in those areas. Insulation must be applied to the edges of the ceiling to the specified level. 


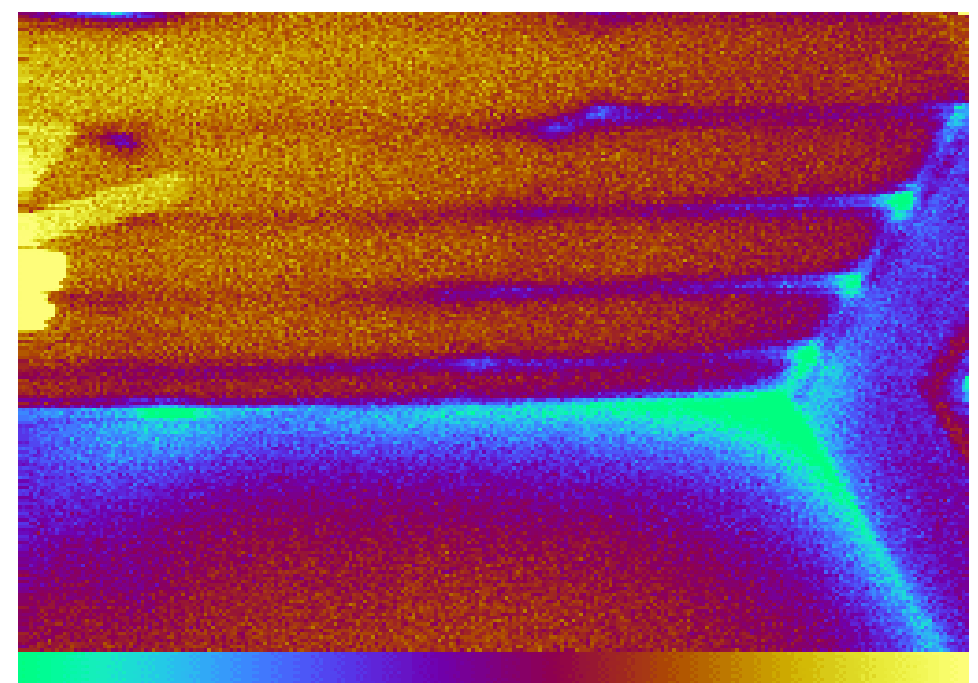

\section{Figure 27. Thermal bridging at ceiling corner}

There is also a problem with thermal bridging where the stove exhaust penetrates the ceiling, as evidenced by a green and blue patch in that area (see Figure 28). This is probably from a gap in the insulation. It appears to be the same level of thermal bridging as that found along the window frames, which is the same color. The heat loss from these areas may be reduced with better caulking and improved window frames. Care must be taken to seal all penetrations.

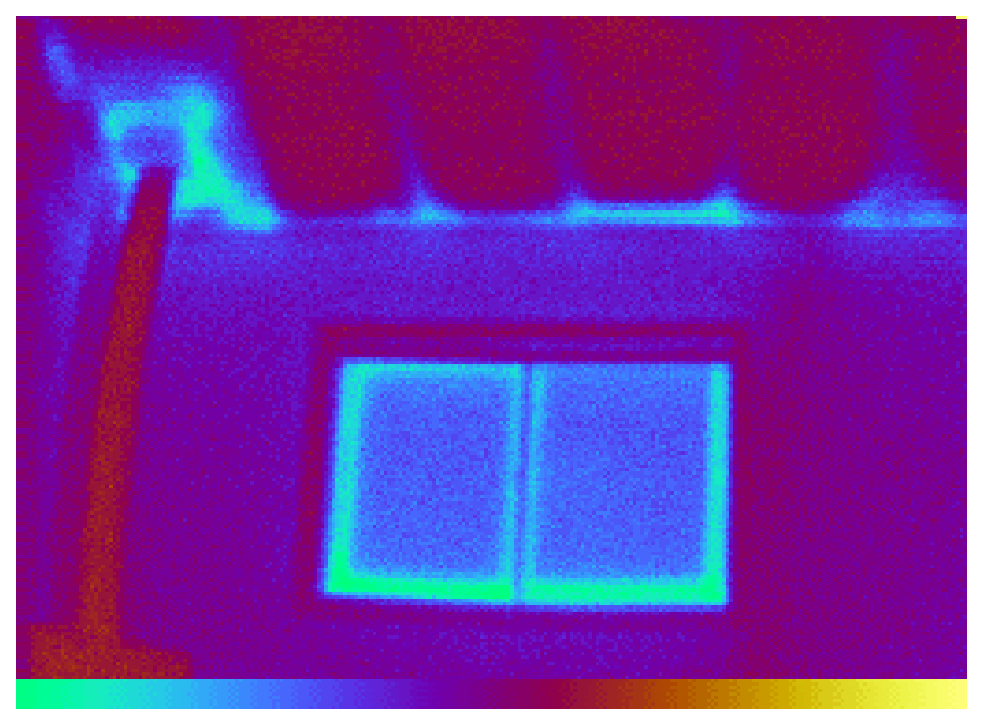

Figure 28. Thermal bridging at roof penetration of chimney and at window frame 


\section{Chapter 5 - Analysis, Recommendations, and Conclusions}

\subsection{Overall Performance Issues}

Tierra I performance is $56 \%$ better than the HERS/MEC base case, but it did not achieve the $70 \%$ savings goal. The thermal mass of the house worked as expected in reducing the temperature swings, and the airtight construction was effective in reducing infiltration. However, there was less solar gain than expected from preliminary modeling. Because additional solar gain was anticipated, the level of insulation was reduced to match the anticipated gains with the losses.

\subsection{Glazing Issues}

Solar gain problems were identified primarily through the STEM results, which indicated the effective solar gains of Tierra I were only $73 \%$ of the predicted value. Because Tierra I relies on passive solar gain as the primary source of heating, it is important to understand what caused the large discrepancy. The problem could come from incorrect glazing models, poorly performing windows, or extrapolating vertical insolation from measured horizontal data. Underestimating the effect of shading from mullions, screens, and other obstructions also affects the results.

The first area examined for possible discrepancy was the glazing model used for estimating the solar gains. The STEM test results, which showed the over-prediction in solar gains, are based on the SERIRES thermal simulation engine. SERI-RES predicts solar gains of 59.7 MMBtu (17.5 MW.hr), while SUNREL, which has an improved diffuse shading model [21] and can use WINDOW 4.1 glazing description files, predicts solar gains of only 49.7 MMBtu per year (14.6 MW·hr) with the same house description. The SUNREL model predictions are closer to the actual results. The STEM software cannot account for this $17 \%$ drop in estimated solar gains because it uses the SERI-RES model.

Additional overestimation may result from having derived the beam and diffuse radiation falling on the vertical plane from radiation measured on a horizontal plane. These models make assumptions about ground reflectivity and the diffuse nature of the sky. Measured data was not available to determine the effect on the building model. Future efforts should use multiple pyranometers to determine the radiation values.

It is also important to determine whether the performance of the low-E windows meets manufacturers' specifications and the consequential effects on the actual house. Such an analysis is beyond the scope of this report. Methods of testing windows in the whole building are needed to quantify this information. Future work in this area should help provide better initial energy-use estimates so that better optimization can be performed.

The last glazing issue related to modeling is to better estimate the window parameters, including area and shading effects, during the design phase. The sensitivity to solar gains on the performance is large; therefore, window characteristics have a large effect on total performance. The effect of the mullions is 3-dimensional and cannot be considered an opaque 2-D surface. The screens alter the shading coefficient of the glass as well as the boundary layer.

With tighter construction and higher insulation levels, passive solar gains contribute to a larger percentage of the heating loads of passive solar homes. This requires glazing systems to be modeled more accurately to better predict performance. 


\subsection{Ground Issues}

The other major modeling problem area identified was the ground heat loss. Tierra I was constructed with perimeter insulation (see Figure 29) but without insulation under the slab. The calibrated model showed that ground heat loss accounted for $37 \%$ of the total heat loss, indicating that the slab should be insulated. With this estimated level of heat loss, variations in the ground model can substantially change the building performance estimates. Proper models are needed to determine recommended insulation levels.

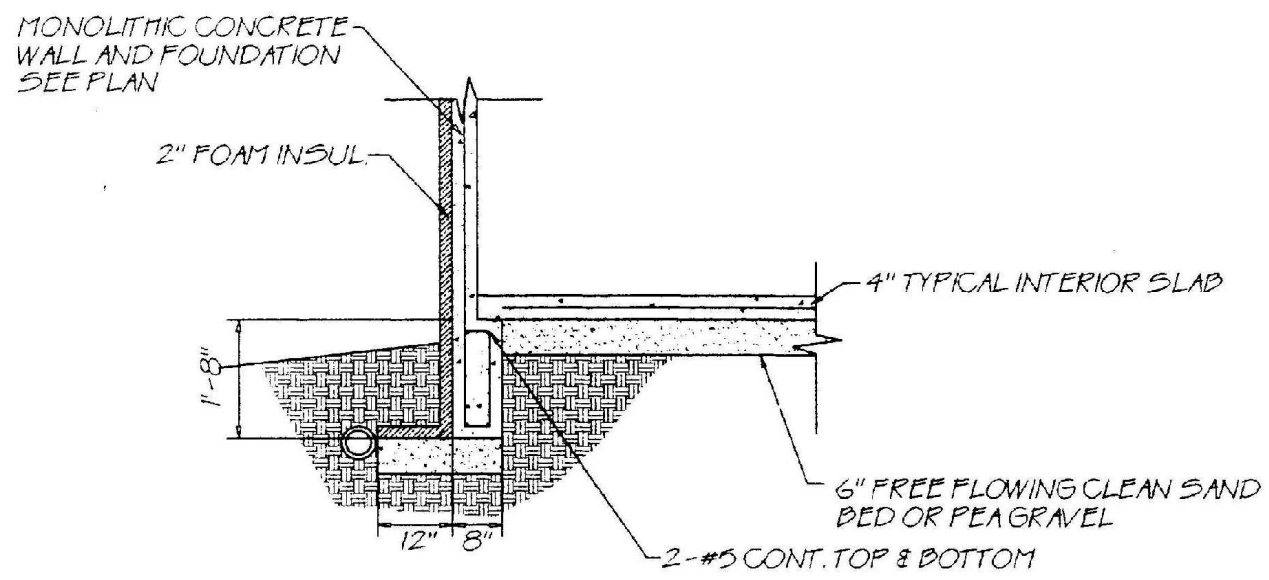

Figure 29. Foundation insulation detail

Ground loss is simulated with two separate slab sections in the SUNREL model (Figure 30). The first section represents the insulated perimeter. It is modeled as a concrete layer with an insulation layer and $1.5 \mathrm{ft}(0.46 \mathrm{~m})$ of dirt connected to the ambient node. The area of this section is the equivalent of a $4 \mathrm{ft}$ $(1.22 \mathrm{~m})$ wide strip around the edge of the slab. The second section is modeled as a concrete layer with $4.5 \mathrm{ft}(1.4 \mathrm{~m})$ of dirt between it and the ground node. This model, based on ASHRAE models [20], is onedimensional even though ground loss is a three-dimensional effect. 


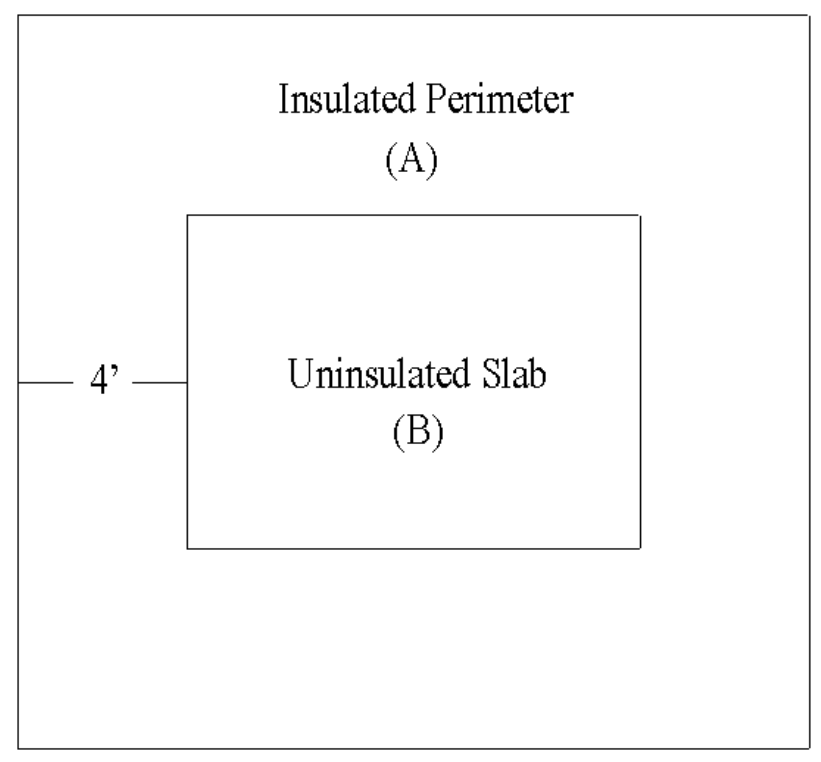

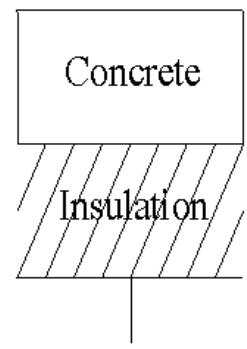

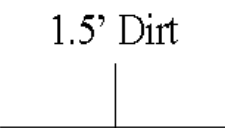

Ambient

(A)

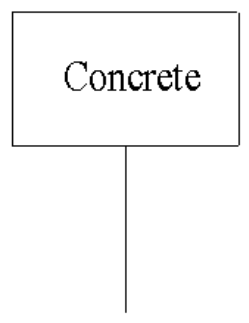

$4.5^{\prime}$ Dirt

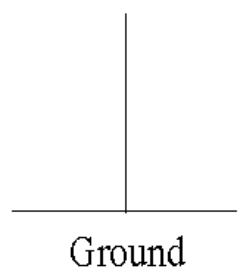

(B)

Figure 30. Diagram of ground loss model

There is no data with which to determine the accuracy of the model because ground-heat loss was not measured for Tierra I. Future projects should measure ground-heat flow data to determine the accuracy of the ground models and to verify the predicted percentages of total heat loss.

\subsection{Design Improvement Based on Lessons Learned}

Changes to the design were made to see if a $70 \%$ saving could be obtained while assuming the lower effective glazing SC as determined in Section 3.8. Results from the thermal analysis and model calibration indicated significant improvements would result from increased insulation for the walls and floor. The wall insulation was increased from 2 inches to 3 inches of polyisocyanurate $\left(\mathrm{R}-21 \mathrm{ft}{ }^{2} \cdot{ }^{\circ} \mathrm{F} \cdot \mathrm{hr} / \mathrm{Btu}\right.$ $\left.\left[10.1 \mathrm{~m}^{2} \cdot \mathrm{K} / \mathrm{W}\right]\right)$ and 2 inches of foam insulation $\left(\mathrm{R}-10 \mathrm{ft}^{2} \cdot{ }^{\circ} \mathrm{F} \cdot \mathrm{hr} / \mathrm{Btu}\left[4.8 \mathrm{~m}^{2} \cdot \mathrm{K} / \mathrm{W}\right]\right)$ were added under the entire slab. That was sufficient to achieve the $70 \%$ savings goal.

\subsection{Improved Design Results}

The improved design has a total heating load of 14.72 MMBtu (4.31 MW.hr) per year and a cooling load of $0.28 \mathrm{MMBtu}(82.1 \mathrm{~kW} \cdot \mathrm{hr}$ ) per year, which is $70.4 \%$ less than the base case. Heat-loss breakdown for the improved design is shown in Figure 31. The two largest heat losses are through the windows and floor. Window heat loss can be reduced by using windows with lower U-values; however, this comes with a trade off because windows with lower U-values often have lower solar gains. The ground-heat loss could be reduced by increasing insulation levels, but this might not be practical or necessary. Improved ground-loss modeling will help give a better estimate of ground-heat loss contribution, as well as optimal insulation levels. 


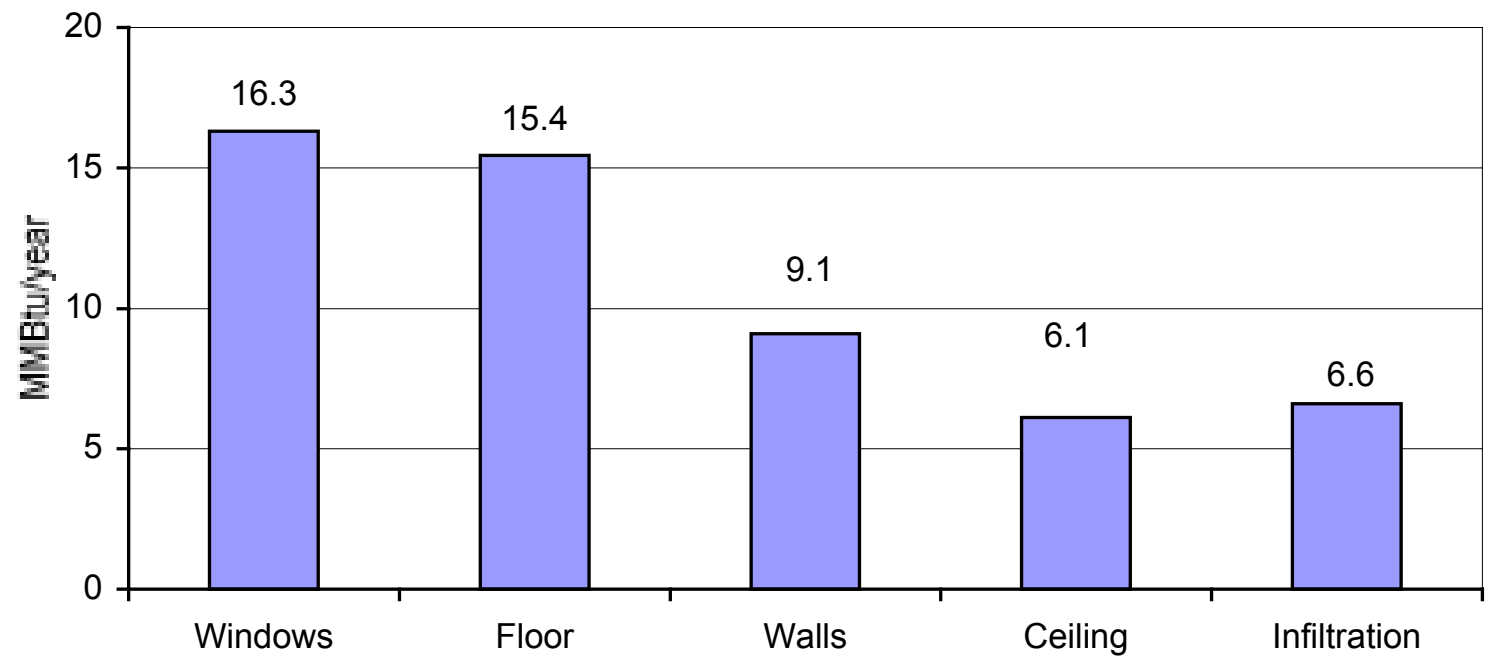

Figure 31. Breakdown of heat loss in improved design model

\subsection{Lessons Learned}

Several important lessons were learned as a result of this study:

1. Scaling up the design does not result in the same energy savings percentages. The savings predicted for the smaller design was 94\% [4] while the predicted savings for the larger design was only $70 \%$ (56\% actual) (see section 3.7).

2. Improved ground-loss models are needed. Ground loss plays a significant role in the total heat loss compared to the rest of the thermal envelope. This heat loss needs to be characterized better to enable us to make more accurate predictions of ground loss and to determine the appropriate perimeter and slab insulation levels.

3. Insulation under the slab is needed. Modeling of the improved design showed that insulating all parts of the slab and not just the perimeter helped achieve desired savings.

4. The glazing needs to be modeled better. The glazing models have improved, but a better method needs to be implemented for entering correct window characteristics, including mullions and screens.

5. The need for mechanical cooling in some climates can be eliminated with proper design. Without night venting, the indoor temperature was only a few degrees above the thermal comfort zone, and modeling showed that the temperatures would remain within the comfort zone if proper venting was used.

6. Movable shading is useful in reducing cooling loads even with fixed overhangs because of diffuse radiation [22]. It is possible to replace all overhang shading with movable shading for optimal heating and cooling loads; however, overhangs work independent of occupant behavior and can be sized for a minimal impact to the heating load.

\subsection{Final Recommendations}

Future houses should be designed and engineered based on actual floor area. The size of the model influences the volume-to-outside-surface-area ratio, which influences optimal window area and insulation levels. The size also affects the perimeter-to-floor-area ratio, resulting in differing ground insulation level recommendations. Scaling is not effective in passive solar design. 
The low-energy passive solar building depends heavily on solar gains, so it is important to get the glazing area in the model correct to obtain a good estimate of the heating loads. It was noted in section 5.2 that the new SUNREL model gives a more accurate estimate for solar gains. Therefore, SUNREL modeling should replace SERI-RES modeling.

Results from the STEM test, infrared imaging, and modeling indicated a need for increased insulation levels. Wall insulation should be increased to 3 inches of polyisocyanurate $\left(\mathrm{R}-21 \mathrm{ft}{ }^{2} \cdot{ }^{\circ} \mathrm{F} \cdot \mathrm{hr} / \mathrm{Btu}[10.1\right.$ $\left.\left.\mathrm{m}^{2} \cdot \mathrm{K} / \mathrm{W}\right]\right)$. A minimum of 2 inches of insulation $\left(\mathrm{R}-10 \mathrm{ft}^{2} \cdot{ }^{\circ} \mathrm{F} \cdot \mathrm{hr} / \mathrm{Btu}\left[4.8 \mathrm{~m}^{2} \cdot \mathrm{K} / \mathrm{W}\right]\right)$ should be added under the entire slab to reduce the ground heat loss during the heating season. Additional care should also be taken to reduce the heat loss, visible in the infrared images, between the roof and the top of the walls.

\subsection{Future Work}

Work needs to be done in the following areas:

1. Update the STEM 2.0 software to use the SUNREL routines as well as DOE 2.x and other simulation tools.

2. Improve ground-loss models.

3. Improve the SUNREL glazing section so window characteristics are more easily entered into the model. 


\section{References}

1. Energy Information Administration (1995). Energy Consumption Series Buildings and Energy in the 1980s. Department of Energy, DOE/IEA-0555 (95)/1.

2. Home Energy Rating Systems (HERS) Council (1996). Guidelines for Uniformity: Voluntary Procedures for Home Energy Ratings.

3. BOCA (1993). Model Energy Code. 1993 Edition, Council of American Building Officials, Building Officials and Code Administration (BOCA).

4. Hayter, S.; Torcellini, P. (1997). "Tierra Concrete Homes: Low-Energy Residential Building Design." 22nd National Passive Solar Conference Proceedings, American Solar Energy Society.

5. Deru, M,; Torcellini, P. ; Judkoff, R. Sunrel Program and Technical Reference Manual. National Renewable Energy Laboratory, Golden, CO. Draft, 1999.

6. Marion, W.; Wilcox, S. (1995). Solar Radiation Data Manual for Buildings. National Renewable Energy Laboratory, Golden, CO. NREL/TP-463-7904.

7. American Society of Heating, Refrigerating, and Air-Conditioning Engineers (1989). ASHRAE Standard 62-1989.

8. Williams, S. (June 1999). "Xeriscape Landscaping." The Ohio State University WebGarden. http://www.ag.usask.ca/cofa/departments/ hort/hortinfo/yards/xeri1.html. accessed March 2001.

9. Judkoff, R.; O’Doherty, B.; Palmiter, L.; Whelling, T.; Wortman, D.; Simms, D. (1983). SERI-RES (Solar Energy Research Institute-Residential Energy Simulator) Version 1.0. "A Computer-Aided Passive-Solar Design Tool for Residential and Light Commercial Buildings. " Solar Energy Research Institute (now the National Renewable Energy Laboratory), Golden, CO.

10. Arasteh, D.K.; Finlayson, E.U.; Huizenga, C. (1994). WINDOW 4.1: Program Description: A PC Program for Analyzing the Thermal Performance of Fenestration Products. Lawrence Berkeley Laboratory, LBL-35298 TA-315, Berkeley.

11. Ohio Semitronics Inc., Model WL4OR Watt Transducer manufacturer specifications.

12. Li-Cor Li200 manufacturer's specifications (Li-Cor).

13. Vaisala Capacitive Humidity Sensor manufacturer specifications.

14. RMYound Model 03001 manufacturer specifications.

15. Balcomb, J.D.; Burch, J.D.; Subbarao, K.; Westby, R.D.; Hancock, C.E. (1994). "Short-Term Energy Monitoring for Commercial Buildings." Proceedings 1994 Summer Study: American Council for an Energy-Efficient Economy, August 28-September 3, 1994. 
16. Subbarao, K.; Burch, J.D.; Hancock, C.E.; Lekov, A.; Balcomb, J.D. (1988). Short-Term Energy Monitoring (STEM): Application of the PSTAR Method to a Residence in Fredericksburg, Virginia. SERI/TR-254-3356, Golden, CO: Solar Energy Research Institute (now NREL), Golden, CO.

17. Barker, G. (1998). STEMWIN 2.01beta Software. National Renewable Energy Laboratory, Golden, $\mathrm{CO}$.

18. Balcomb, J.D.; Burch, J.D. (1993). "Short-Term Energy Monitoring of Residences.” ASHRAE Transactions Proceedings. ASHRAE, Atlanta, GA.

19. Subarao, K. (1988). PSTAR - Primary and Secondary Terms Analysis and Renormalization. SERI/TR-254-3175, Golden, CO: Solar Energy Research Institute.

20. American Society of Heating, Refrigeration and Air-Conditioning Engineers, Inc. (1993). ASHRAE Handbook: Fundamentals, Atlanta, GA.

21. Deru, M. (1996). Improvements to the SERI-RES/Sunrel Building Energy Simulation Program. Colorado State University Thesis.

22. Lau, A. (1998). "Fixed Overhangs for Controlling Solar Gain: The good news and the bad." 23rd National Passive Solar Conference Proceedings, American Solar Energy Society.

23. Judkoff, R.; Balcomb, J.D.; Hancock, C.E.; Barker, G.; Subarao, K. Side-by-Side Thermal Tests of Modular Offices: A Validation Study of the STEM Method. NREL/TP-550-23940, Golden, CO 2000

24. National Climatic Data Center (1999) http://www.ncdc.noaa.gov. Accessed March 2001.

25. The Energy Conservatory. Minneapolis Blower Door: Operation Manual Model 3. (1992). Minneapolis, MN. 


\section{Appendix A-The STEM/PSTAR Method}

The STEM/PSTAR test method has been used successfully on more than 100 residential buildings and 6 commercial buildings. The term STEM refers to the test itself and the subsequent analysis. PSTAR refers to the mathematical formalism used to separate building energy flows into convenient segments [19]. The method provides a means of separating effects that tend to be mixed together in the monitored data from a building. This separation allows the user to identify the three primary thermal characteristics of the building: (1) the BLC, (2) the effective building mass, and (3) the effective solar gain area. An adjusted model can then be used to predict future building performance. The PSTAR method minimizes cross talk between the three characteristics; an important advantage.

An approximate thermal simulation model for the building is developed based on a quick audit of the plans. NREL uses the SERI-RES simulation program, although, in principle, one could use any simulator. The advantage of starting with a detailed simulation model of the building (instead of taking a black-box approach) is that known building characteristics amenable to direct observation are imbedded in the model. Of primary importance is the distribution of primary mass elements and the size, orientation, and shading of all windows. The former allows one to predict an appropriate mix of fast and slow dynamic responses, and the latter allows data from a short-term test carried out during one season to be used to predict performance in another season, even though sun angles may be quite different. Accurate modeling of other details, such as thermal bridges and the effectiveness of insulation, is not as important because BLC will subsequently be renormalized.

In the PSTAR procedure, the heat flow into the room air is mathematically separated into nine terms relating to the effect causing the heat flow. This disaggregation of terms is unusual, but is central to the PSTAR method. During the test, these are the only terms considered. Therefore, if energy is to be balanced, the sum of the nine terms should be equal to zero at each hour. The sum is called $Q_{\text {net }}$ and is calculated as an hourly data stream throughout the test. Non-zero values of $\mathrm{Q}_{\text {net }}$ indicate the inability of the model to balance energy at that particular hour.

In a typical application, three of the major energy-flow terms are determined. This is accomplished by multiplying each of these terms by a constant re-normalization factor. The constants are chosen to force the average value of $\mathrm{Q}_{\text {net }}$ to zero during carefully chosen periods of the test. The re-normalization is done in three steps.

Step one is performed during a period of 2 to 4 hours at the end of a night when the inside temperature has remained reasonably steady (this is called the co-heating period). The dominant terms during this period are the heat input from the electric heaters and the heat losses by conduction and infiltration. Heat storage, solar, and other effects are small but not negligible. The steady-state conduction term is multiplied by the renormalization factor to achieve an exact energy balance for the co-heating period.

Steps two and three are similar. The energy-flow term caused by discharge of building mass is dominant during the cool-down period. The solar-gain term is usually large during the daytime hours. Re-normalization factors for these terms are determined based on the whole data period.

The three steps are repeated until the re-normalization constants stabilize. If the model is reasonably accurate, $\mathrm{Q}_{\text {net }}$ should be small throughout the test period. Root-mean-square values of $\mathrm{Q}_{\text {net }}$ for residential tests have typically been in the range of $100 \mathrm{Btu} / \mathrm{hr}(29 \mathrm{~W})$ at night and $1700 \mathrm{Btu} / \mathrm{hr}(498 \mathrm{~W})$ during the day.

A validation of the STEM method has shown that averaged results from repeated STEM tests can detect differences in the BLC in the 5\% range and STEM is effective at determining changes in thermal mass [23]. 


\section{Appendix B-Heat Gain Ratios}

\section{$\underline{\text { Solar Heat Gain Coefficient (SHGC) }}$}

The SHGC is the fraction of incident irradiance that enters through the glazing as heat gain. A window with no glass would have a SHGC of 1.00 .

\section{Shading Coefficient (SC)}

The SC is the ratio of solar gain of the window to that of a reference piece of glass. Typically, this reference is a standard reference window of single-pane, double-strength, clear glass. Therefore,

$$
S C=\frac{S H G C_{\text {test }}}{S H G C_{r e f}}[20],
$$

where $\mathrm{SHGC}_{\mathrm{ref}}=0.86$ for single-pane, double-strength, clear glass. Product literature typically uses this value for comparison purposes.

\section{$\underline{\text { Shading Factor (SF) }}$}

The term SF, used by SUNREL and SERI-RES, is the ratio of solar gain of the window to that of an $n$-pane, double-strength, clear glass, where $n$ is the same for both the reference and test sample.

$S F=\frac{S C}{S C_{\text {clear }}}$,

where $\mathrm{SC}_{\text {clear }}$ is 0.89 for double-pane glass.

Examples:

\begin{tabular}{|l|c|c|c|}
\hline \multicolumn{1}{|c|}{ Glass Type } & SHGC & SC & SF \\
\hline Single-pane - clear & 0.86 & 1.00 & 1.00 \\
\hline Double-pane - clear & 0.77 & 0.89 & 1.00 \\
\hline Triple-pane - clear & 0.65 & 0.76 & 1.00 \\
\hline Double-pane - low-E & 0.55 & 0.64 & 0.72 \\
\hline
\end{tabular}

Note: Many low-E combinations are available. 


\section{Appendix C-HERS/MEC Base Case Calculations}

The base-case house conforms to the HERS Guidelines [2] guideline \#13 and the 1995 Model Energy Code [1].

Building geometry as specified by HERS A.1 and A.2:

- $\quad$ Length $=62.33 \mathrm{ft}$

- Width $=30 \mathrm{ft}$

- Height $=8 \mathrm{ft}$

- $\quad$ Floor area $=1,870 \mathrm{ft}^{2}$

- Window area $=337 \mathrm{ft}^{2}$ (HERS A.6) including 27\% framing (HERS A.9)

- $\quad$ Area doors $=40 \mathrm{ft}^{2}$ (HERS B.3)

Building insulation levels:

- $\mathrm{U}_{\mathrm{o}}=0.14 \mathrm{Btu} / \mathrm{hr} \cdot \mathrm{ft}^{2} \cdot{ }^{\circ} \mathrm{F}\left(0.24 \mathrm{~W} / \mathrm{m}^{2} \cdot \mathrm{K}\right)($ MEC Chapter 5, Section 502.2)

- $\mathrm{U}_{\mathrm{w}}=0.058 \mathrm{Btu} / \mathrm{hr} \cdot \mathrm{ft}^{2} \cdot{ }^{\circ} \mathrm{F}\left(0.1004 \mathrm{~W} / \mathrm{m}^{2} \cdot \mathrm{K}\right)$ (HERS Table 6a)

- $\mathrm{U}_{\mathrm{f}}=0.40 \mathrm{Btu} / \mathrm{hr} \cdot \mathrm{ft}^{2} \cdot{ }^{\circ} \mathrm{F}\left(0.69 \mathrm{~W} / \mathrm{m}^{2} \cdot \mathrm{K}\right)($ HERS section A.3.c)

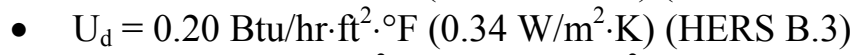

- $\mathrm{U}_{\mathrm{r}}=0.028 \mathrm{Btu} / \mathrm{hr} \cdot \mathrm{ft}^{2} \cdot{ }^{\circ} \mathrm{F}\left(0.048 \mathrm{~W} / \mathrm{m}^{2} \cdot \mathrm{K}\right)($ MEC Chapter 8 , Figure 2)

- $\mathrm{R}_{\text {slab }}=4.4 \mathrm{hr} \cdot \mathrm{ft}^{2} \cdot{ }^{\circ} \mathrm{F} / \mathrm{Btu}\left(2.5 \mathrm{~m}^{2} \cdot \mathrm{K} / \mathrm{W}\right)(\mathrm{MEC}$ Chapter 8 , Figure 3$)$

$\mathrm{U}_{\mathrm{o}}$ : U value for gross wall area

$\mathrm{U}_{\mathrm{w}}: \mathrm{U}$ value for opaque wall area including framing

$\mathrm{U}_{\mathrm{f}}$ : $\mathrm{U}$ value for glazing area

$\mathrm{U}_{\mathrm{d}}$ : $\mathrm{U}$ value for doors

$\mathrm{U}_{\mathrm{r}}$ : U value for ceiling/roof

$\mathrm{R}_{\text {slab }}$ : Foundation/perimeter insulation

Additional specifications:

- $\quad$ Slab-on-grade as specified by HERS A.4

- 0.67 ACH (Air Changes per Hour) (HERS B.1)

- $\mathrm{SC}=0.7$ during cooling season and 0.89 during heating season from HERS B.2

- Wall solar absorptivity $=0.50$ from HERS A.5

- Roof solar absorptivity $=0.75$ from HERS A.5

- Internal mass $=8 \mathrm{lbs} / \mathrm{ft}^{2}\left(39 \mathrm{~kg} / \mathrm{m}^{2}\right)$ from HERS B.4

The SUNREL building description file for the HERS/MEC base case house is located in Appendix F. 


\section{Appendix D-Sensible and Latent Gain Schedules}

Table D1. Sensible and Latent Gain Sources

\begin{tabular}{|l|r|r|r|r|}
\hline Source & Number & \multicolumn{1}{|l|}{ Sensible Btu/hr } & Latent Btu/hr & Hr/day \\
\hline Lights & 8 & 136 & 0 & 6 \\
\hline Refrigerator & 1 & 389 & 0 & 24 \\
\hline People-day & 3 & 230 & 190 & 6 \\
\hline People-night & 3 & 161 & 133 & 8 \\
\hline
\end{tabular}

Table D2. Sensible and Latent Schedules

\begin{tabular}{|l|l|l|l|l|l|l|l|}
\hline Hr & $\begin{array}{l}\text { Lights } \\
(\mathrm{Btu} / \mathrm{hr})\end{array}$ & $\begin{array}{l}\text { Cooking } \\
(\mathrm{Btu} / \mathrm{hr})\end{array}$ & $\begin{array}{l}\text { Refrigerator } \\
(\mathrm{Btu} / \mathrm{hr})\end{array}$ & $\begin{array}{l}\text { People } \\
(\mathrm{Btu} / \mathrm{hr})\end{array}$ & $\begin{array}{l}\text { Total Sensible } \\
(\mathrm{kBtu} / \mathrm{hr})\end{array}$ & $\begin{array}{l}\text { People } \\
(\mathrm{Btu} / \mathrm{hr})\end{array}$ & $\begin{array}{l}\text { Total } \\
\text { Latent } \\
(\mathrm{kBtu} / \mathrm{hr})\end{array}$ \\
\hline 1 & & & 389 & 483 & 0.872 & 399 & 0.399 \\
\hline 2 & & & 389 & 483 & 0.872 & 399 & 0.399 \\
\hline 3 & & & 389 & 483 & 0.872 & 399 & 0.399 \\
\hline 4 & & & 389 & 483 & 0.872 & 399 & 0.399 \\
\hline 5 & & & 389 & 483 & 0.872 & 399 & 0.399 \\
\hline 6 & 1088 & 1500 & 389 & 690 & 3.667 & 570 & 0.570 \\
\hline 7 & 1088 & 1500 & 389 & 690 & 3.667 & 570 & 0.570 \\
\hline 8 & & & 389 & & 0.389 & & \\
\hline 9 & & & 389 & & 0.389 & & \\
\hline 10 & & & 389 & & 0.389 & & \\
\hline 11 & & & 389 & & 0.389 & & \\
\hline 12 & & & 389 & & 0.389 & & \\
\hline 13 & & & 389 & & 0.389 & & \\
\hline 14 & & & 389 & & 0.389 & & \\
\hline 15 & & & 389 & & 0.389 & & \\
\hline 16 & & & 389 & & 0.389 & & \\
\hline 17 & & & 389 & & 0.389 & & \\
\hline 18 & 1088 & 1500 & 389 & 690 & 3.667 & 570 & 0.570 \\
\hline 19 & 1088 & 1500 & 389 & 690 & 3.667 & 570 & 0.570 \\
\hline 20 & 1088 & 1500 & 389 & 690 & 3.667 & 570 & 0.570 \\
\hline 21 & 1088 & 1500 & 389 & 690 & 3.667 & 570 & 0.570 \\
\hline 22 & & & 389 & 483 & 0.872 & 399 & 0.399 \\
\hline 23 & & & 389 & 483 & 0.872 & 399 & 0.399 \\
\hline 24 & & & 389 & 483 & 0.872 & 399 & 0.399 \\
\hline
\end{tabular}




\section{Appendix E-Manual UA Product Calculations}

Table E1. UA Product for Individual Components and the Whole Building

\begin{tabular}{|c|c|c|c|}
\hline Envelope Heat Loss & $\operatorname{Area}\left(\mathrm{ft}^{2}\right)$ & U-value $\left(\right.$ Btu/hr$\left.\cdot \mathbf{f t}^{2} \cdot{ }^{\circ} \mathbf{F}\right)$ & UA $\left(\right.$ Btu $\left./ \mathbf{h r} \cdot{ }^{\circ} \mathbf{F}\right)$ \\
\hline \multicolumn{4}{|l|}{ Ceiling/Roof } \\
\hline Roof & 2150 & 0.0230 & 54.13 \\
\hline \multicolumn{4}{|l|}{ Walls } \\
\hline North & 419 & 0.0828 & 37.00 \\
\hline South & 343 & 0.0828 & 29.72 \\
\hline East & 223 & 0.0817 & 18.46 \\
\hline West & 240 & 0.0817 & 19.61 \\
\hline Clerestory & 126 & 0.0526 & 6.63 \\
\hline \multicolumn{4}{|l|}{ Windows } \\
\hline Glazing & 269 & 0.3600 & 96.84 \\
\hline Framing & 103 & 0.2000 & 20.68 \\
\hline Conduction above ground & & Sub-total & 283.07 \\
\hline Foundation Heat Loss & Perimeter & F2 - Factor * & \\
\hline \multirow[t]{2}{*}{ Slab } & 186 & 0.4 & 74.40 \\
\hline & & Total & 357.47 \\
\hline
\end{tabular}

* - From ASHRAE Fundamentals, 1993. 


\section{Appendix F-SUNREL Building Description Files}

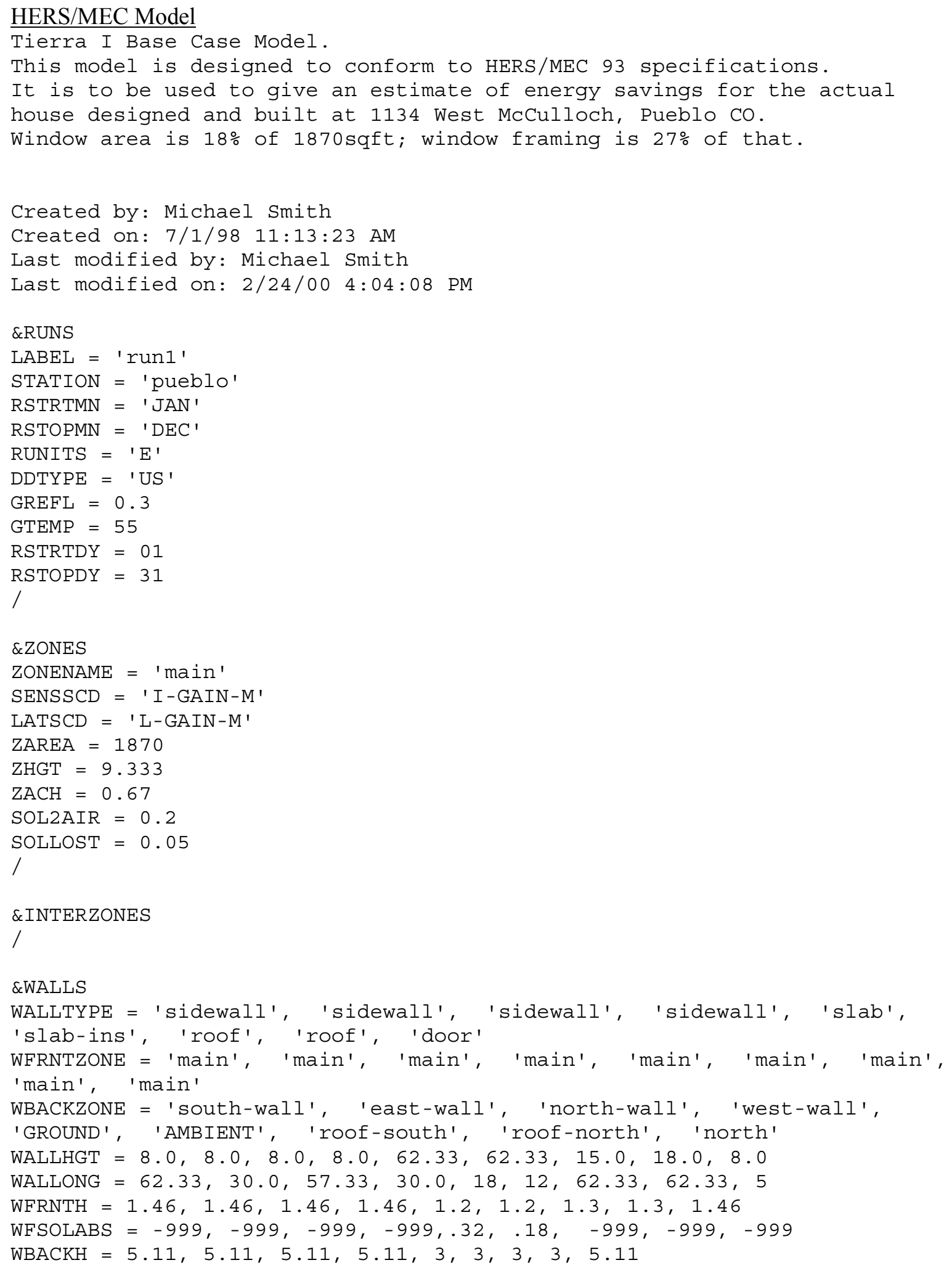




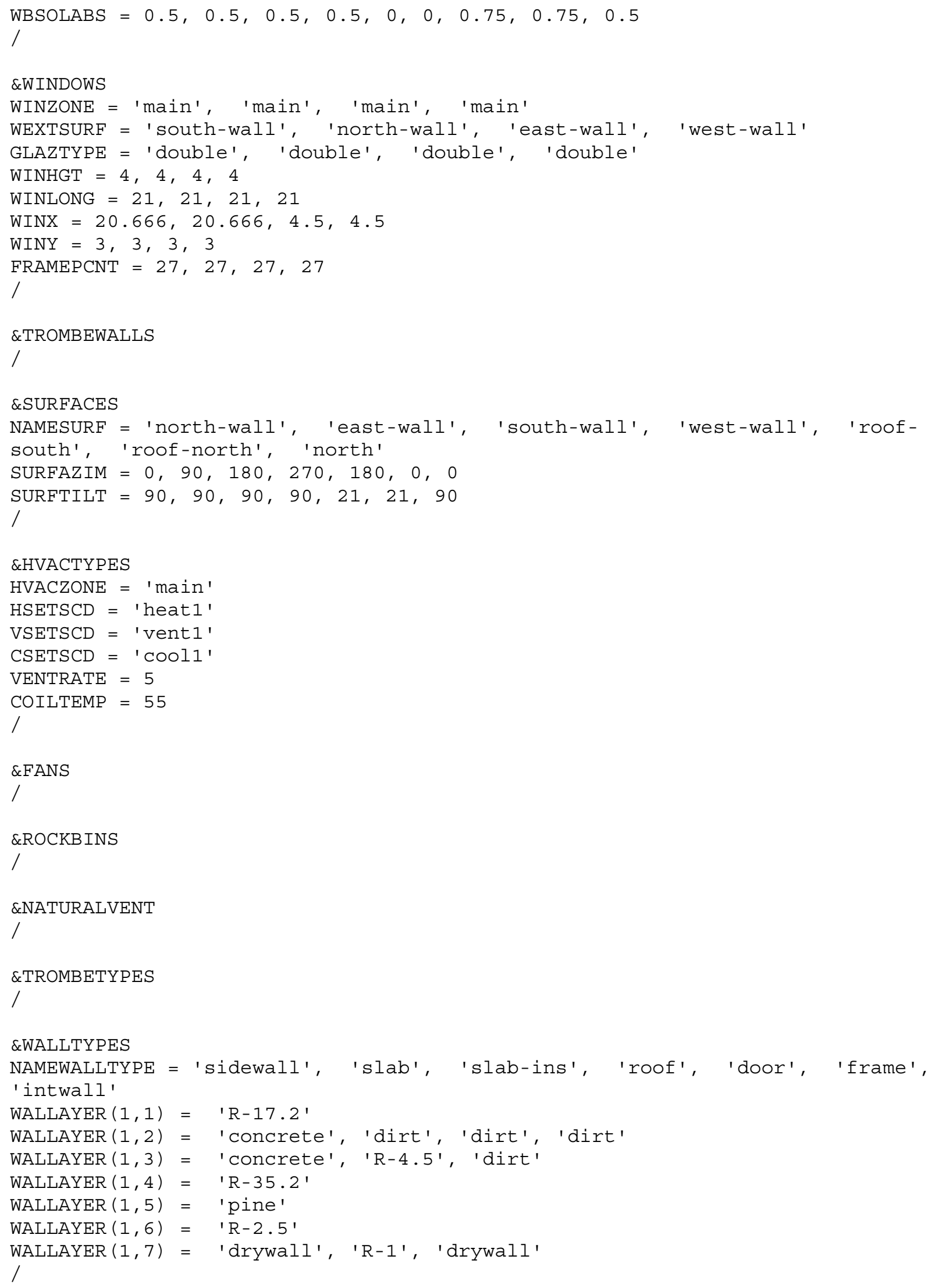




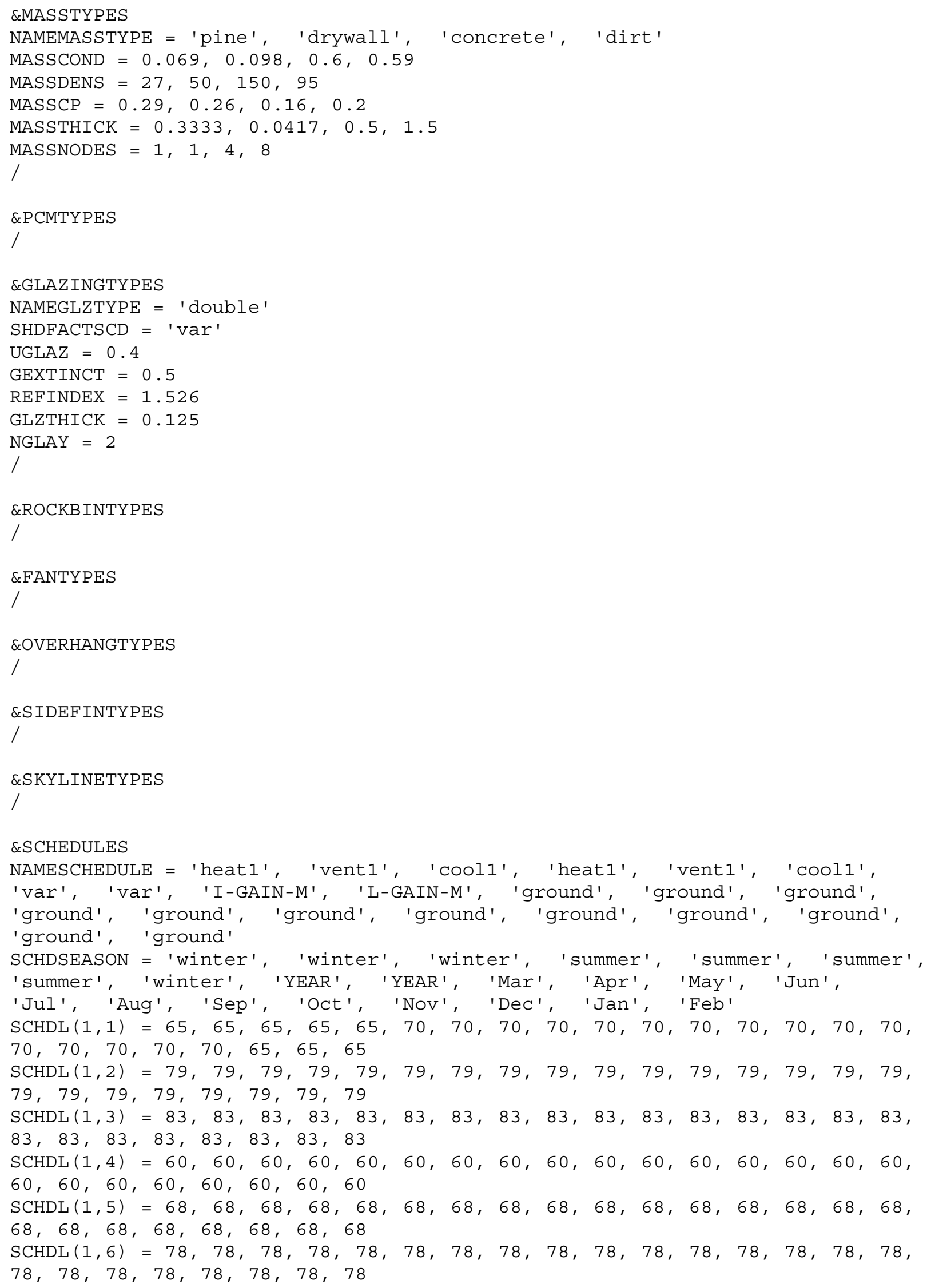


$\operatorname{SCHDL}(1,7)=0.7,0.7,0.7,0.7,0.7,0.7,0.7,0.7,0.7,0.7,0.7,0.7,0.7$, $0.7,0.7,0.7,0.7,0.7,0.7,0.7,0.7,0.7,0.7,0.7$

$\operatorname{SCHDL}(1,8)=0.9,0.9,0.9,0.9,0.9,0.9,0.9,0.9,0.9,0.9,0.9,0.9,0.9$, $0.9,0.9,0.9,0.9,0.9,0.9,0.9,0.9,0.9,0.9,0.9$

$\operatorname{SCHDL}(1,9)=0.872,0.872,0.872,0.872,0.872,3.668,3.668,0.389,0.389$, $0.389,0.389,0.389,0.389,0.389,0.389,0.389,0.389,3.668,3.668,3.668$, $3.668,0.872,0.872,0.872$

$\operatorname{SCHDL}(1,10)=0.399,0.399,0.399,0.399,0.399,0.571,0.571,0.0,0.0,0.0$, $0.0,0.0,0.0,0.0,0.0,0.0,0.0,0.571,0.571,0.571,0.571,0.399,0.399$, 0.399

$\operatorname{SCHDL}(1,11)=31.1,31.1,31.1,31.1,31.1,31.1,31.1,31.1,31.1,31.1$, $31.1,31.1,31.1,31.1,31.1,31.1,31.1,31.1,31.1,31.1,31.1,31.1,31.1$, 31.1

$\operatorname{SCHDL}(1,12)=29.8,29.8,29.8,29.8,29.8,29.8,29.8,29.8,29.8,29.8$, $29.8,29.8,29.8,29.8,29.8,29.8,29.8,29.8,29.8,29.8,29.8,29.8,29.8$, 29.8

$\operatorname{SCHDL}(1,13)=35.1,35.1,35.1,35.1,35.1,35.1,35.1,35.1,35.1,35.1$, $35.1,35.1,35.1,35.1,35.1,35.1,35.1,35.1,35.1,35.1,35.1,35.1,35.1$, 35.1

$\operatorname{SCHDL}(1,14)=41.7,41.7,41.7,41.7,41.7,41.7,41.7,41.7,41.7,41.7$, $41.7,41.7,41.7,41.7,41.7,41.7,41.7,41.7,41.7,41.7,41.7,41.7,41.7$, 41.7

$\operatorname{SCHDL}(1,15)=51.8,51.8,51.8,51.8,51.8,51.8,51.8,51.8,51.8,51.8$, $51.8,51.8,51.8,51.8,51.8,51.8,51.8,51.8,51.8,51.8,51.8,51.8,51.8$, 51.8

$\operatorname{SCHDL}(1,16)=61.1,61.1,61.1,61.1,61.1,61.1,61.1,61.1,61.1,61.1$, $61.1,61.1,61.1,61.1,61.1,61.1,61.1,61.1,61.1,61.1,61.1,61.1,61.1$, 61.1

$\operatorname{SCHDL}(1,17)=71.0,71.0,71.0,71.0,71.0,71.0,71.0,71.0,71.0,71.0$, $71.0,71.0,71.0,71.0,71.0,71.0,71.0,71.0,71.0,71.0,71.0,71.0,71.0$, 71.0

$\operatorname{SCHDL}(1,18)=77.1,77.1,77.1,77.1,77.1,77.1,77.1,77.1,77.1,77.1$, $77.1,77.1,77.1,77.1,77.1,77.1,77.1,77.1,77.1,77.1,77.1,77.1,77.1$, 77.1

$\operatorname{SCHDL}(1,19)=74.3,74.3,74.3,74.3,74.3,74.3,74.3,74.3,74.3,74.3$, $74.3,74.3,74.3,74.3,74.3,74.3,74.3,74.3,74.3,74.3,74.3,74.3,74.3$, 74.3

$\operatorname{SCHDL}(1,20)=65.8,65.8,65.8,65.8,65.8,65.8,65.8,65.8,65.8,65.8$, $65.8,65.8,65.8,65.8,65.8,65.8,65.8,65.8,65.8,65.8,65.8,65.8,65.8$, 65.8

$\operatorname{SCHDL}(1,21)=53.6,53.6,53.6,53.6,53.6,53.6,53.6,53.6,53.6,53.6$, $53.6,53.6,53.6,53.6,53.6,53.6,53.6,53.6,53.6,53.6,53.6,53.6,53.6$, 53.6

$\operatorname{SCHDL}(1,22)=40.5,40.5,40.5,40.5,40.5,40.5,40.5,40.5,40.5,40.5$, $40.5,40.5,40.5,40.5,40.5,40.5,40.5,40.5,40.5,40.5,40.5,40.5,40.5$, 40.5

/

$\& O U T P U T$

OUTTYPE = 'zones', 'walls', 'zones'

PERIOD = 'M', 'M', 'M'

OUTUNITS = 'E', 'E', ' $\mathrm{E}^{\prime}$

OUTSEASON = 'winter', 'winter', 'YEAR'

$\mathrm{FRMT}=$ ' $\mathrm{Y}$ ', 'Y', 'Y'

IOCOMP $=1,-999,1$

IOPAGE $=-999,-999,-999$

/ 


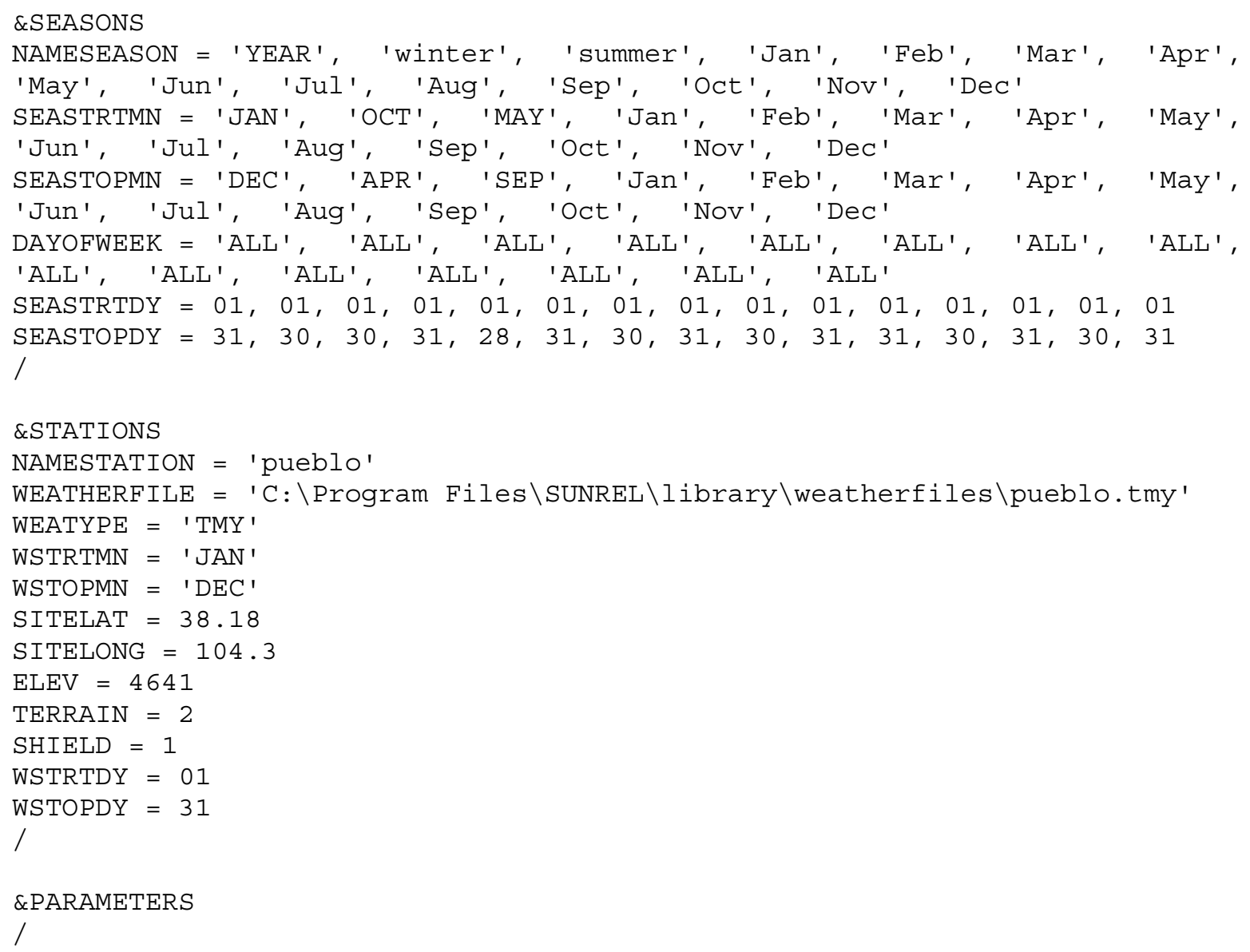




\section{Preconstruction Model}

This is an 1,870 $\mathrm{ft}^{\wedge} 2$ house built by Tierra Concrete Homes in 1996 at 1134 West McCulloch, in Pueblo CO.

The description is based on construction plans.

Created by: Michael Smith

Created on: 7/1/98 11:13:23 AM

Last modified by: Michael Smith

Last modified on: 2/23/00 3:50:27 PM

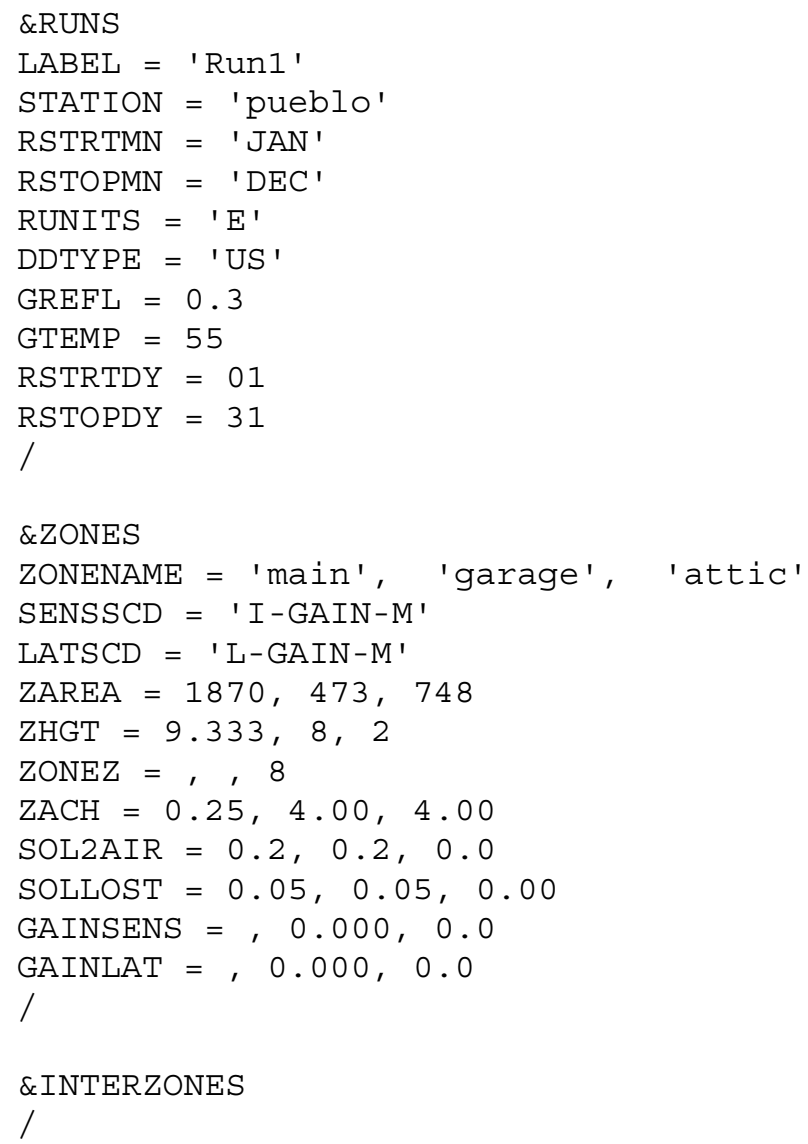




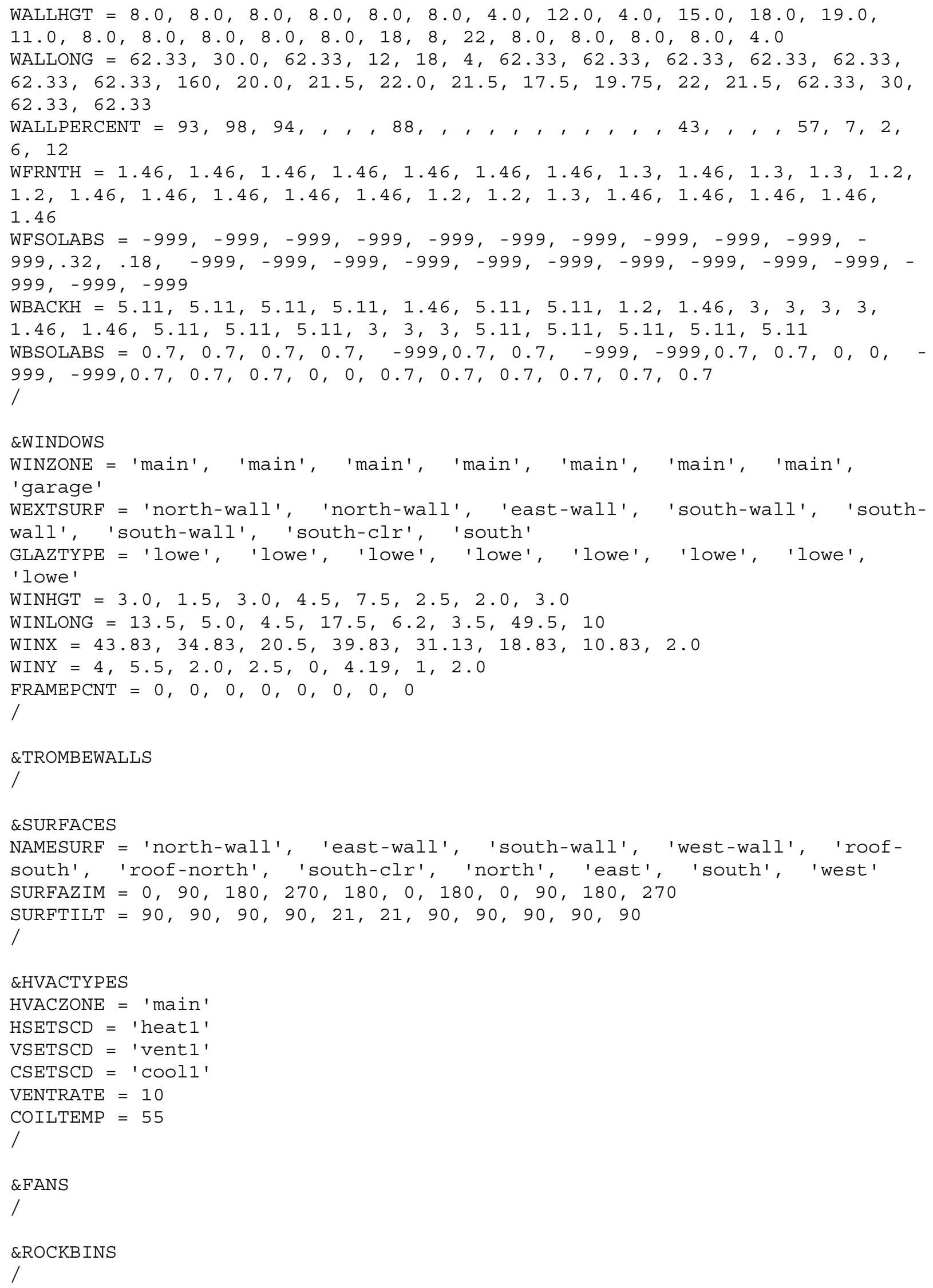




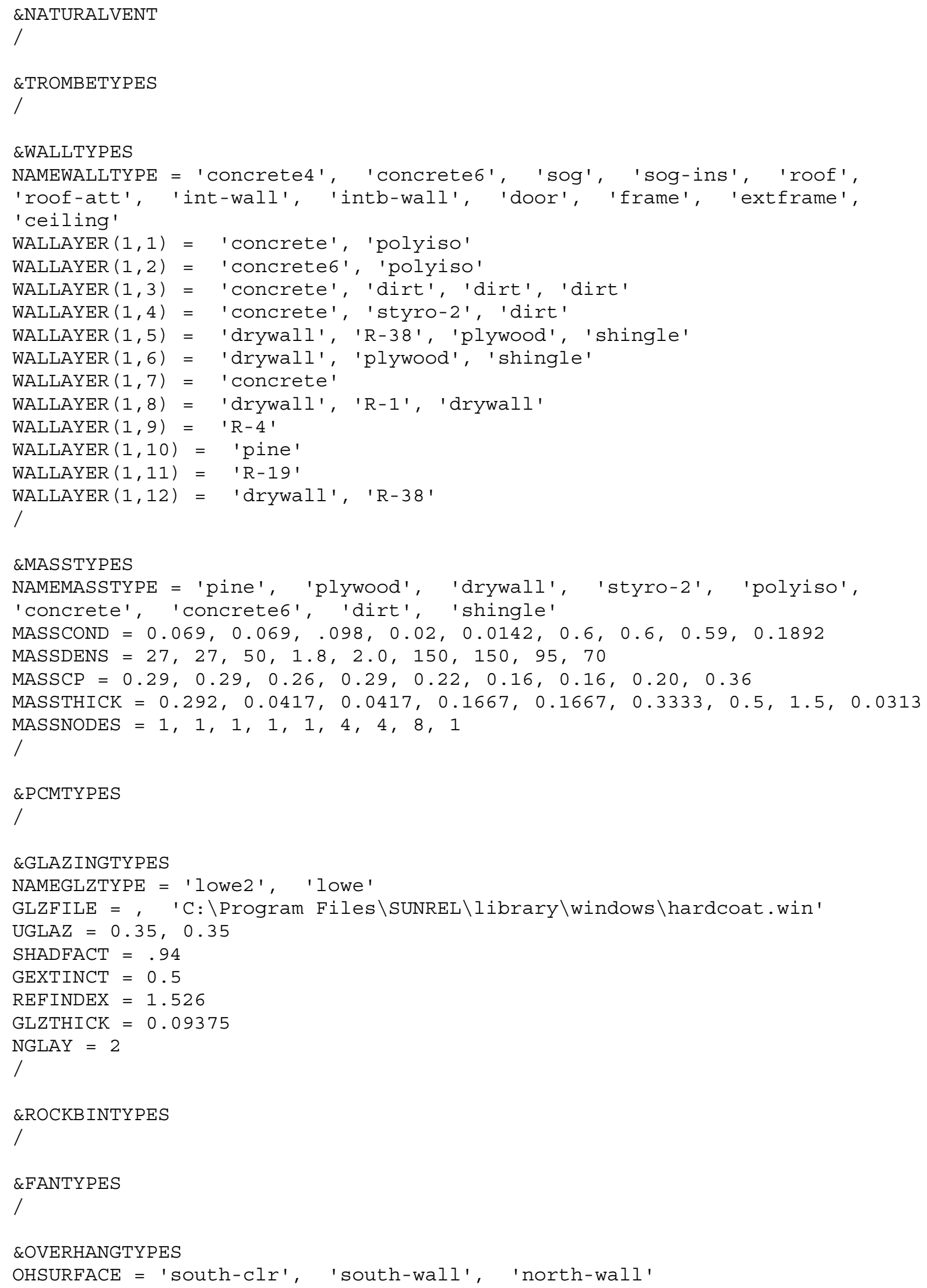




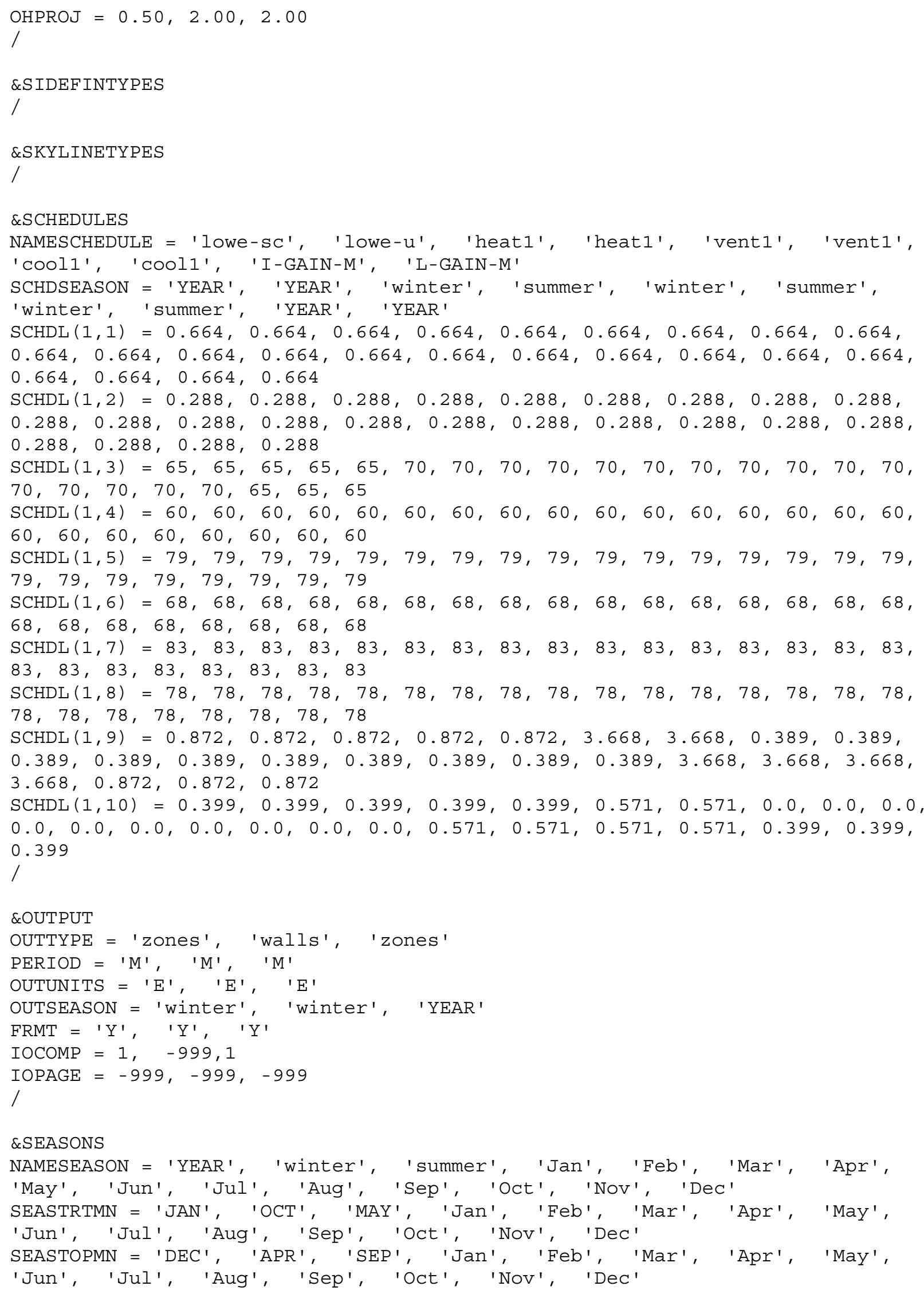




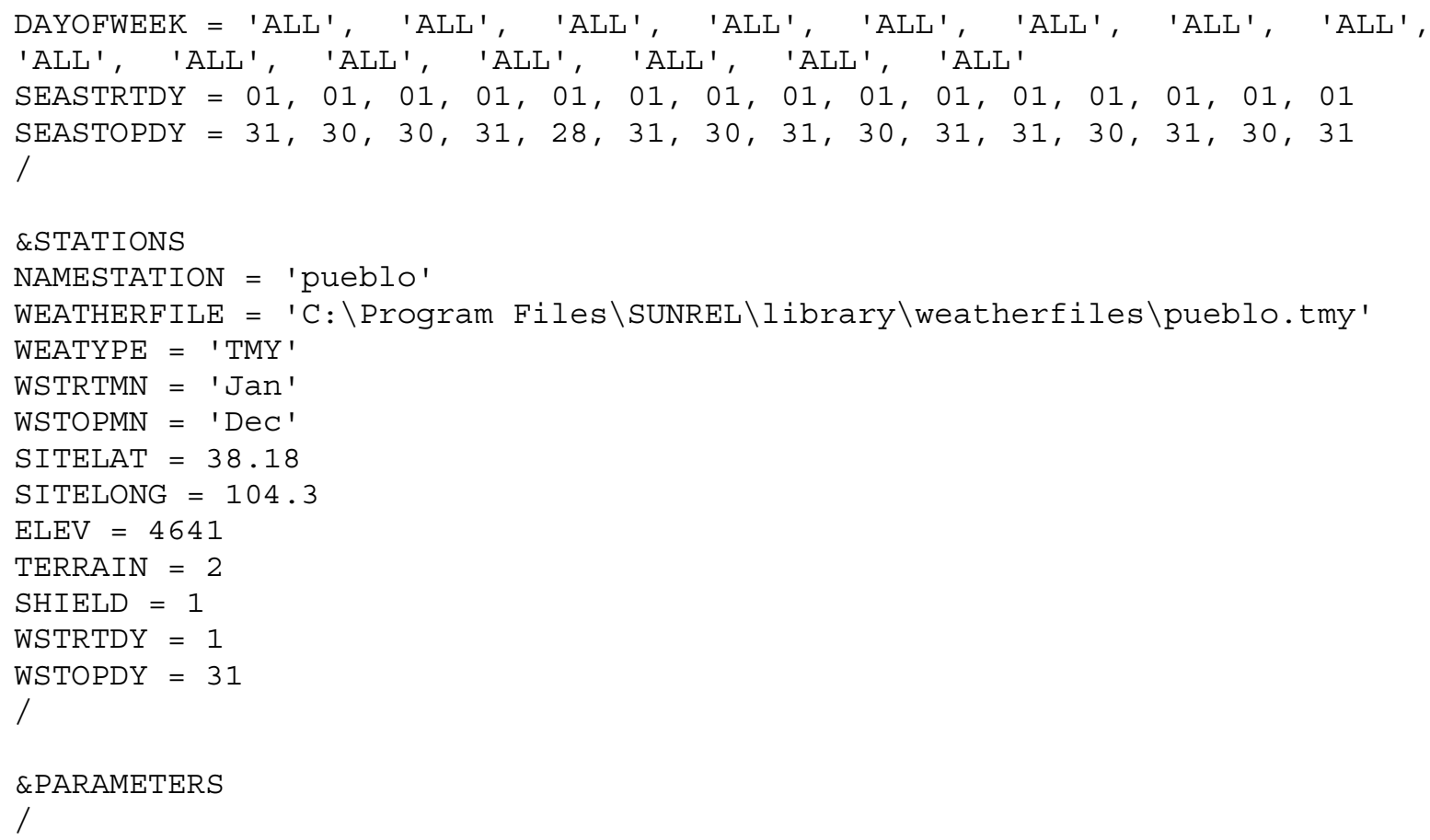




\section{As-built Model}

This is an 1,870 ft^2 house built by Tierra Concrete Homes in 1996 at 1134

West McCulloch, in Pueblo CO.

The building description is updated to account for changes between construction plans and measured values post construction. The change reflects a 9\% decrease in measured glazing area from plans.

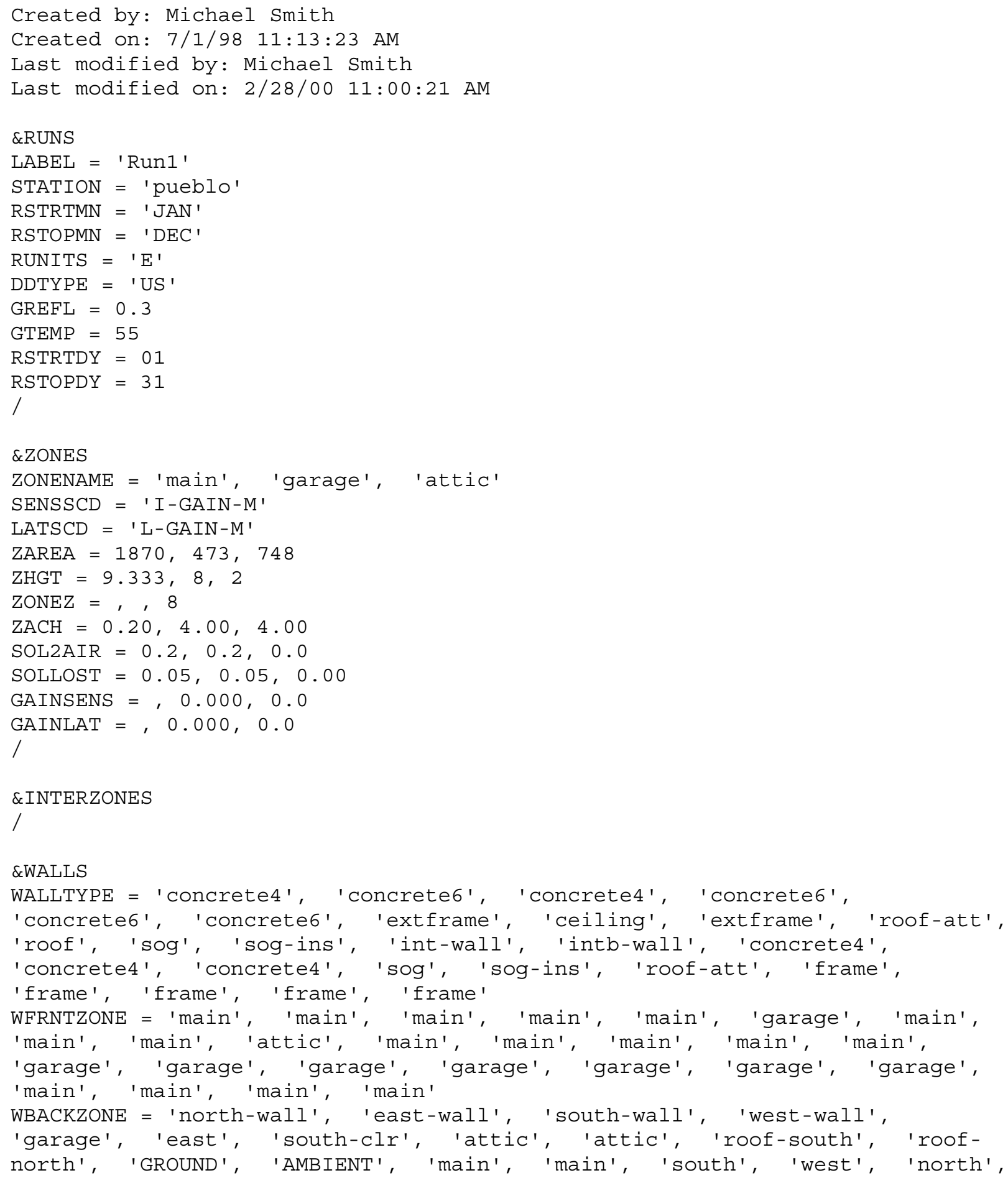




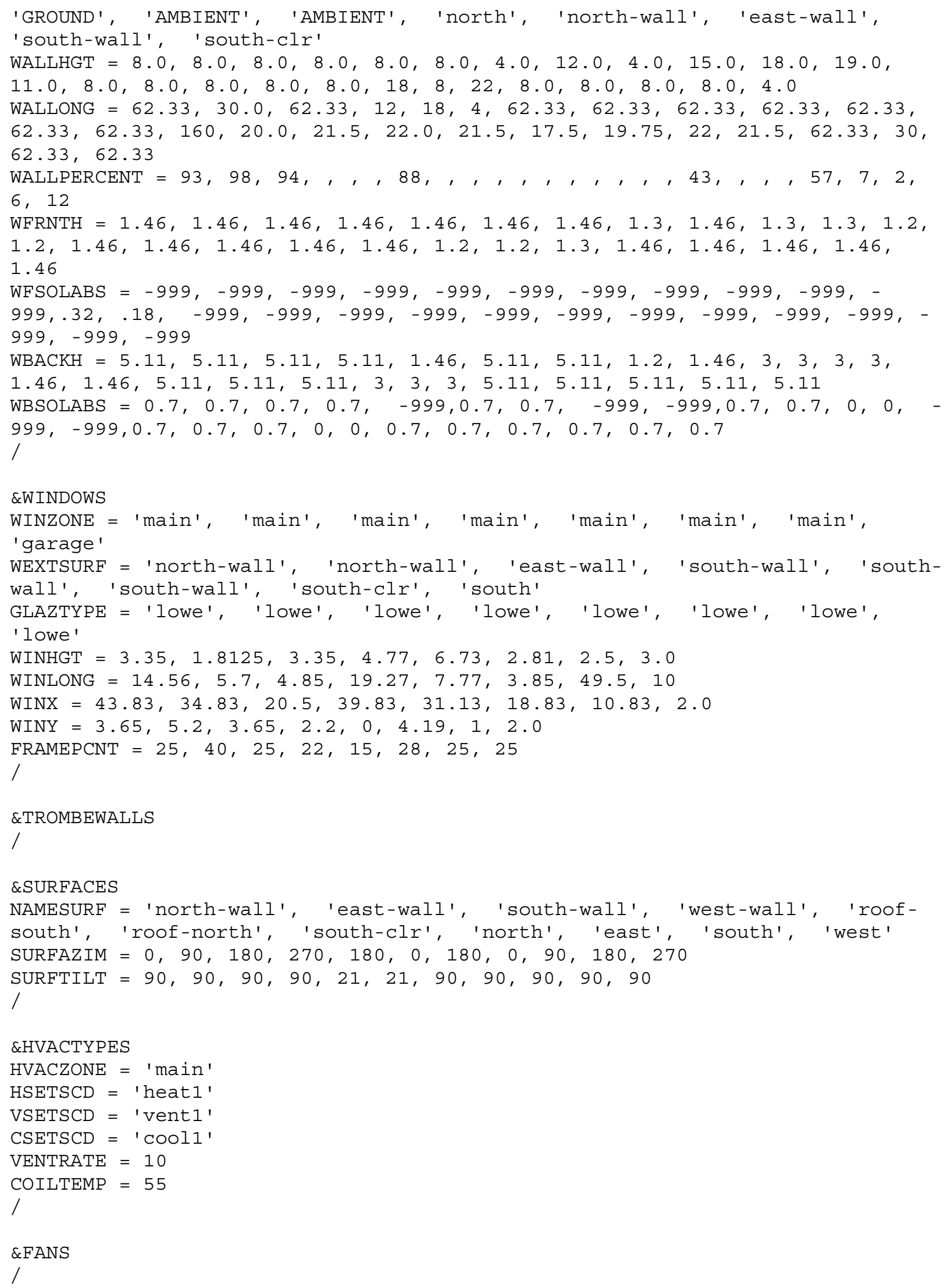




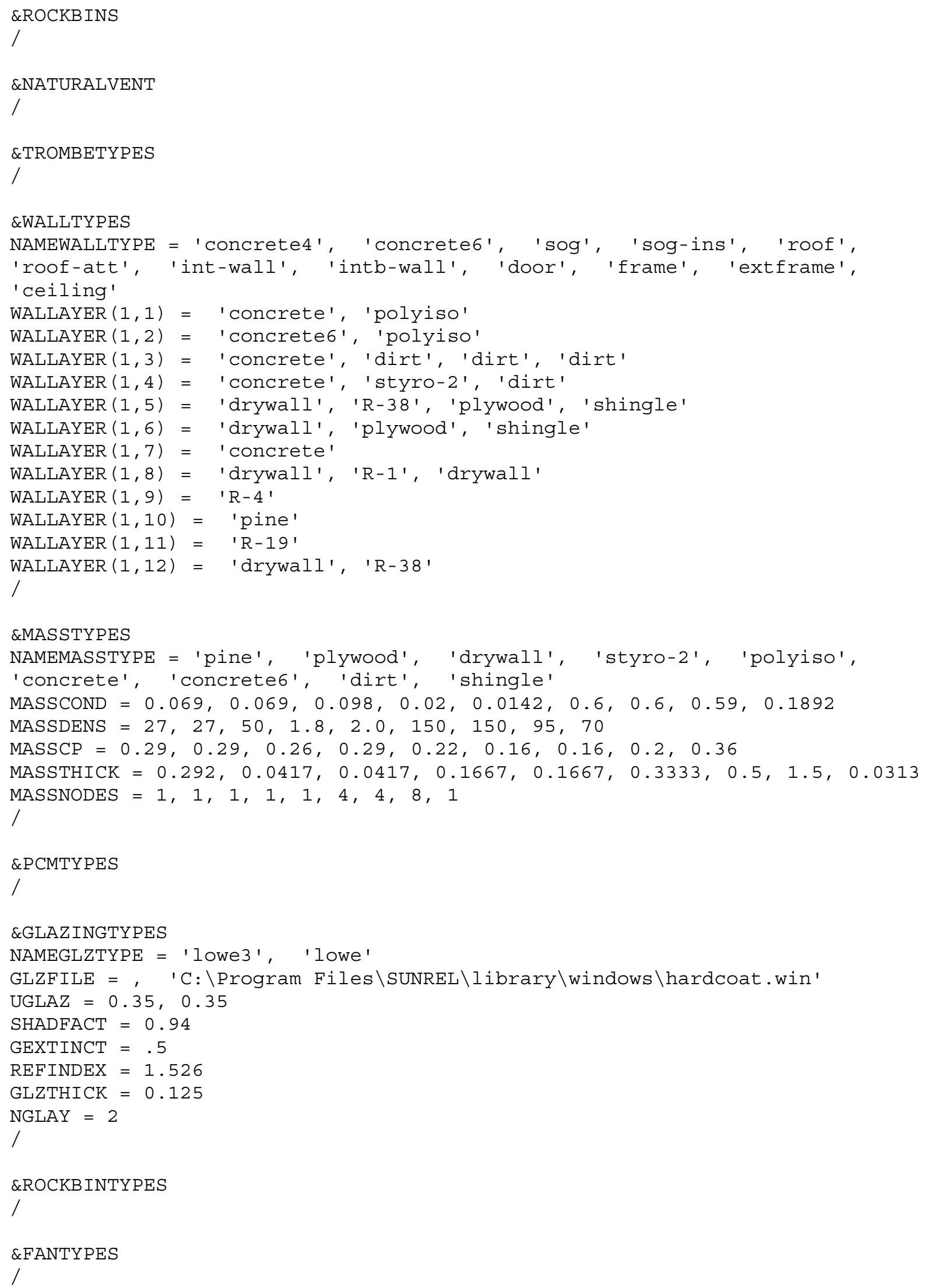




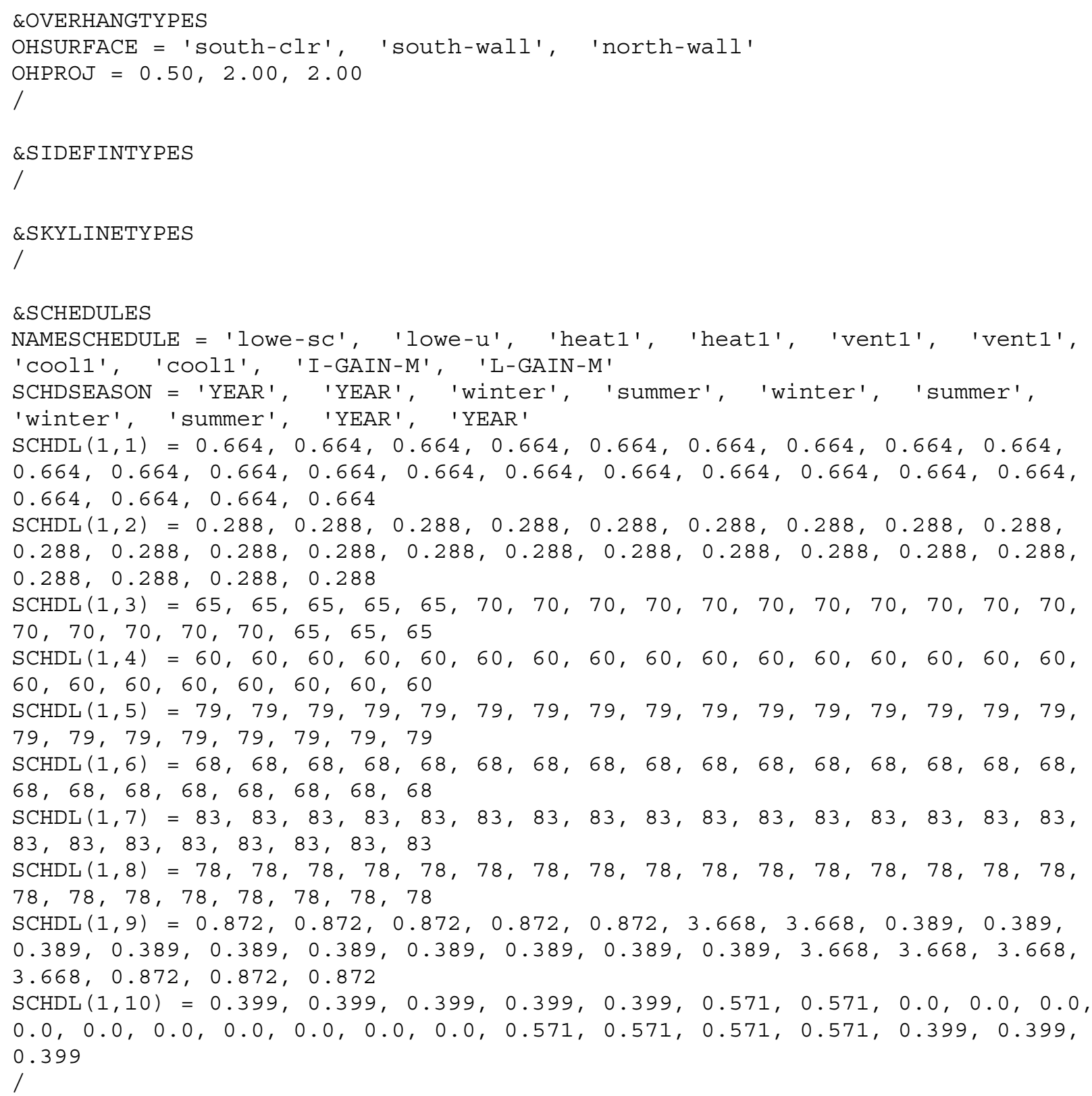




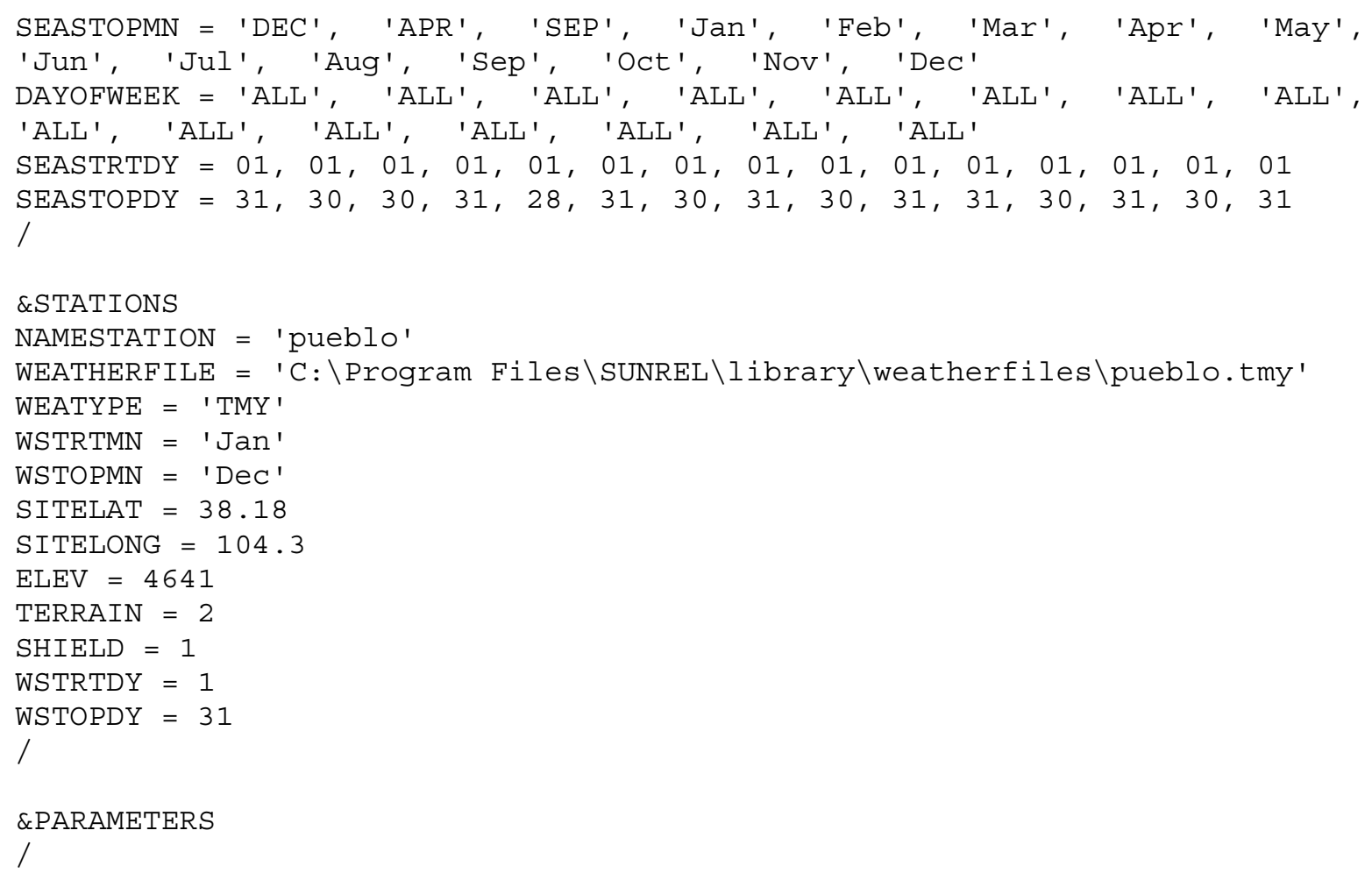


Calibrated Model

This is an 1,870 ft^2 house built by Tierra Concrete Homes in 1996 at 1134 West McCulloch, in Pueblo $\mathrm{CO}$.

The calibrated version of As-built with changes made to more closely match the performance of the actual building.

Created by: Michael Smith

Created on: 7/1/98 11:13:23 AM

Last modified by: Michael Smith

Last modified on: 2/25/00 10:34:19 AM

$\&$ RUNS

LABEL = 'Run1'

STATION = 'pueblo'

RSTRTMN $=$ ' JAN'

RSTOPMN $=$ 'DEC'

RUNITS $=' \mathrm{E}^{\prime}$

DDTYPE $=$ 'US'

GREFL $=0.3$

GTEMP $=55$

RSTRTDY $=01$

RSTOPDY $=31$

/

$\& Z O N E S$

ZONENAME = 'main', 'garage', 'attic'

SENSSCD $=$ 'I-GAIN-M '

LATSCD $=$ 'L-GAIN-M'

ZAREA $=1870,473,748$

$\mathrm{ZHGT}=9.333,8,2$

$\mathrm{ZONEZ}=,, 8$

$\mathrm{ZACH}=, 4.00,4.00$

ZLEAK $=62$

SOL2AIR $=0.2,0.2,0.0$

SOLLOST $=0.05,0.05,0.00$

GAINSENS $=, 0.000,0.0$

GAINLAT $=, 0.000,0.0$

/

$\& I N T E R Z O N E S$

/

$\& W A L L S$

WALLTYPE = 'concrete4', 'concrete6', 'concrete4', 'concrete6',

'concrete6', 'concrete6', 'extframe', 'ceiling', 'extframe', 'roof-att', 'roof', 'sog', 'sog-ins', 'int-wall', 'intb-wall', 'concrete4', 'concrete4', 'concrete4', 'sog', 'sog-ins', 'roof-att', 'frame', 


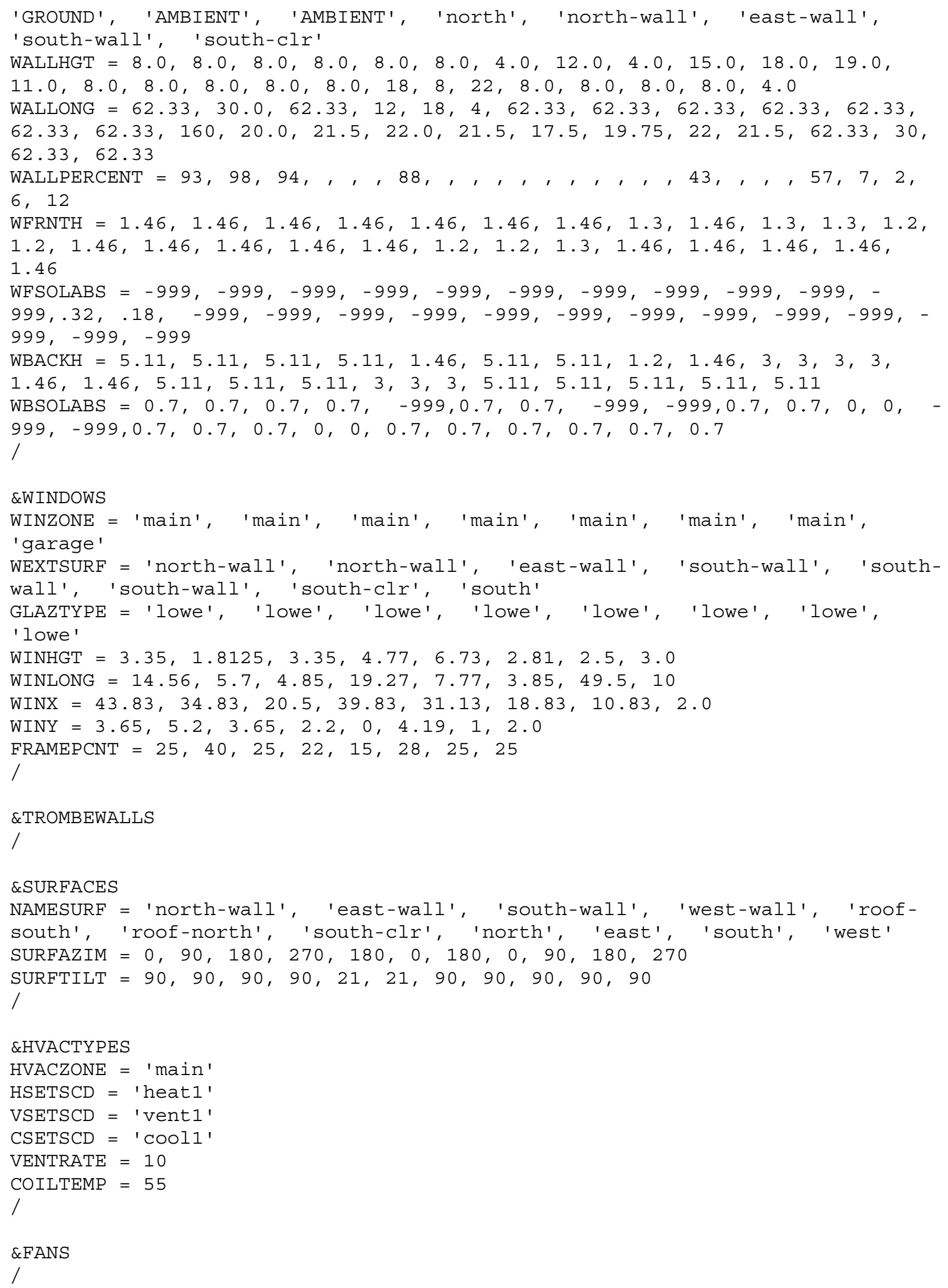




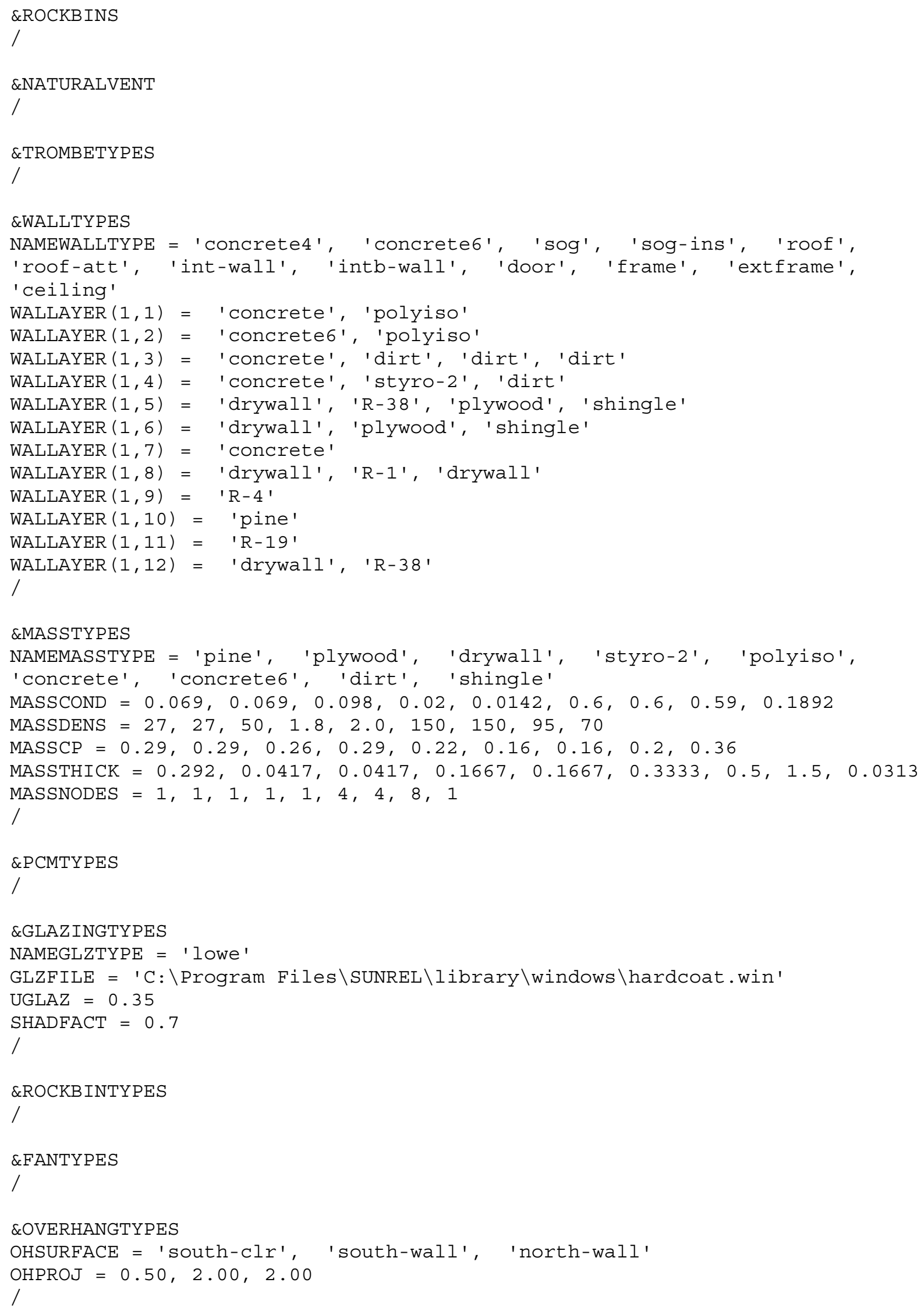




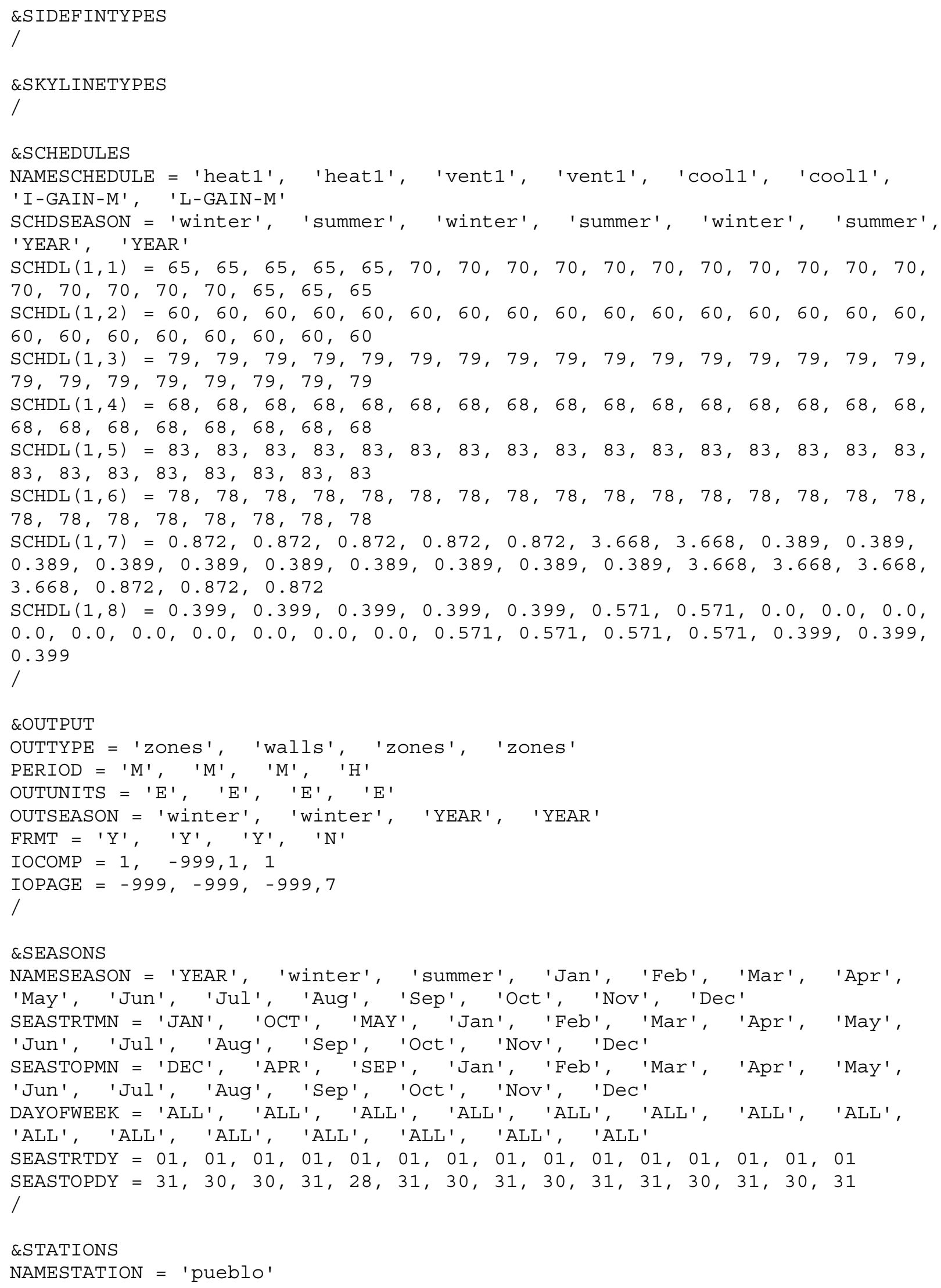




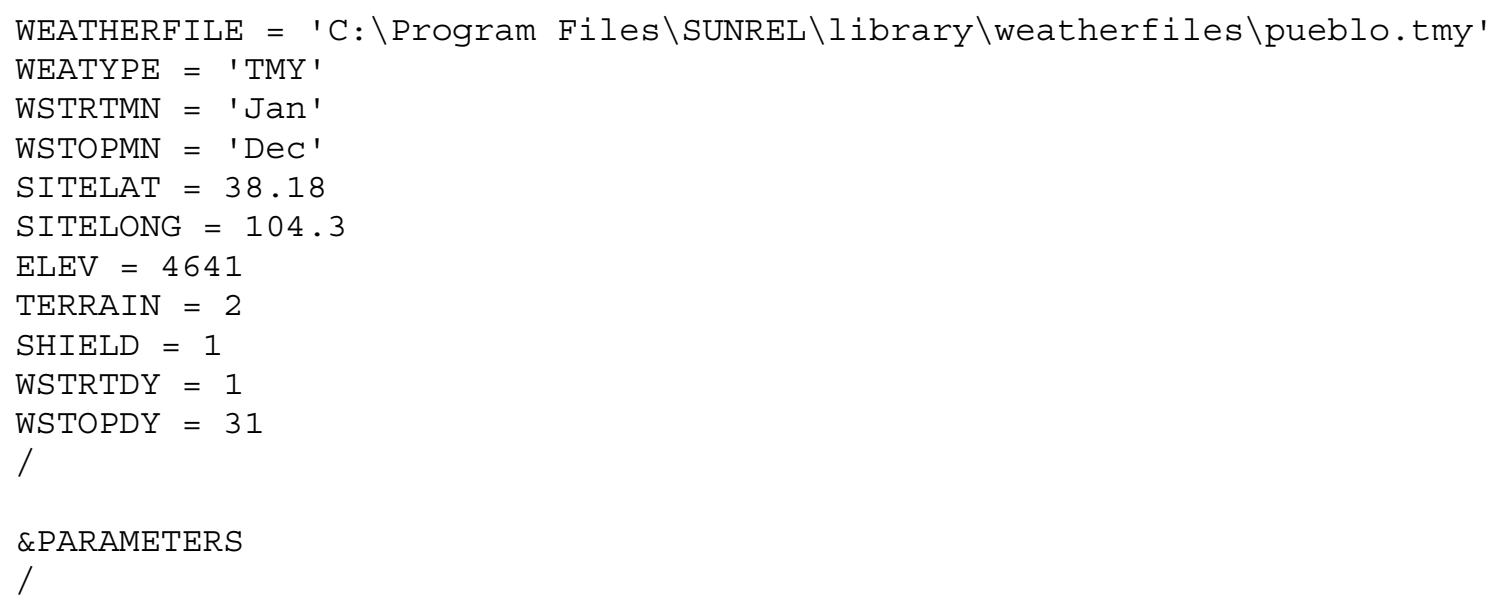




\section{Improved Model}

This is an 1,870 ft^2 house built by Tierra Concrete Homes in 1996 at 1134 West McCulloch, in Pueblo CO.

The calibrated version of As-built with changes made to more closely match the performance of the actual building.

Created by: Michael Smith

Created on: 7/1/98 11:13:23 AM

Last modified by: Michael Smith

Last modified on: 3/2/00 9:12:38 AM

\&RUNS

LABEL = 'Run1'

STATION = 'pueblo'

RSTRTMN $=$ ' JAN'

RSTOPMN $=$ 'DEC'

RUNITS $=' \mathrm{E}^{\prime}$

DDTYPE $=$ 'US'

GREFL $=0.3$

GTEMP $=55$

RSTRTDY $=01$

RSTOPDY $=31$

/

$\& Z O N E S$

ZONENAME = 'main', 'garage', 'attic'

SENSSCD $=$ 'I-GAIN-M'

LATSCD $=$ 'L-GAIN-M'

ZAREA $=1870,473,748$

$\mathrm{ZHGT}=9.333,8,2$

$\mathrm{ZONEZ}=,, 8$

$\mathrm{ZACH}=, 4.00,4.00$

ZLEAK $=62$

SOL2AIR $=0.2,0.2,0.0$

SOLLOST $=0.05,0.05,0.00$

GAINSENS $=, 0.000,0.0$

GAINLAT $=, 0.000,0.0$

/

\&INTERZONES

/

$\& W A L L S$

WALLTYPE = 'concrete4', 'concrete6', 'concrete4', 'concrete6',

'concrete6', 'concrete6', 'extframe', 'ceiling', 'extframe', 'roof-att', 'roof', 'sog', 'sog-ins', 'int-wall', 'intb-wall', 'concrete4', 'concrete4', 'concrete4', 'sog', 'sog-ins', 'roof-att', 'frame', 


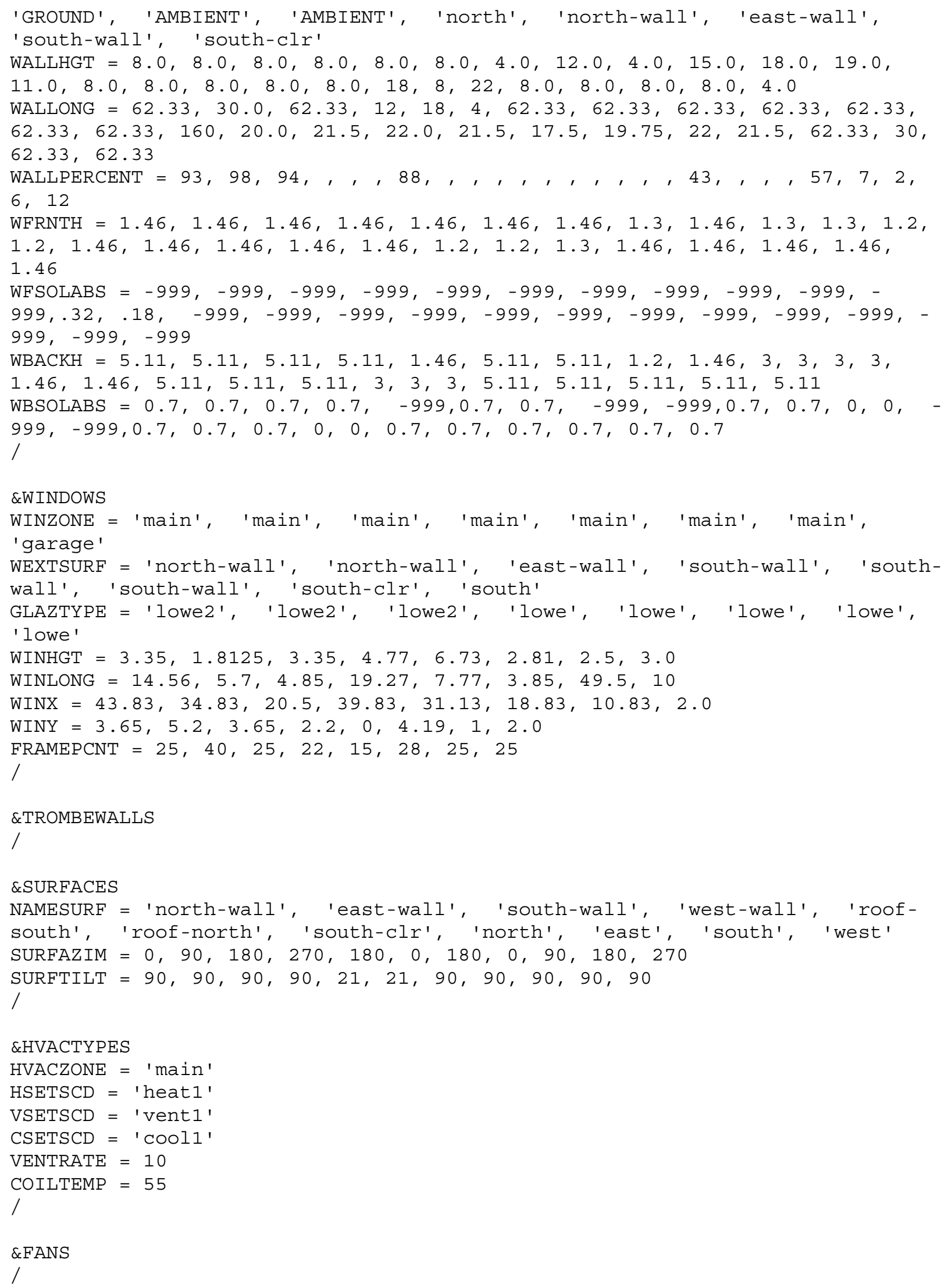




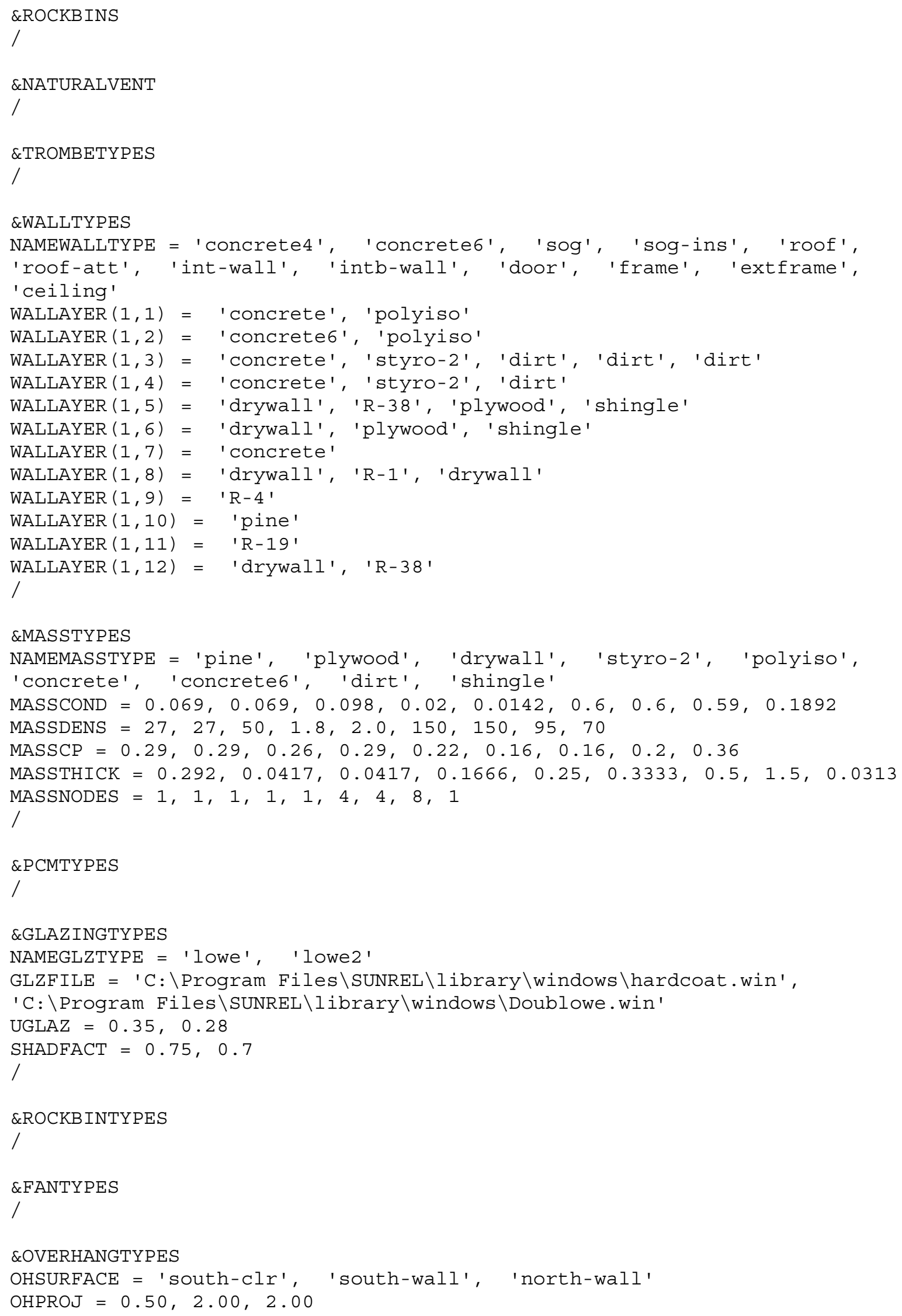




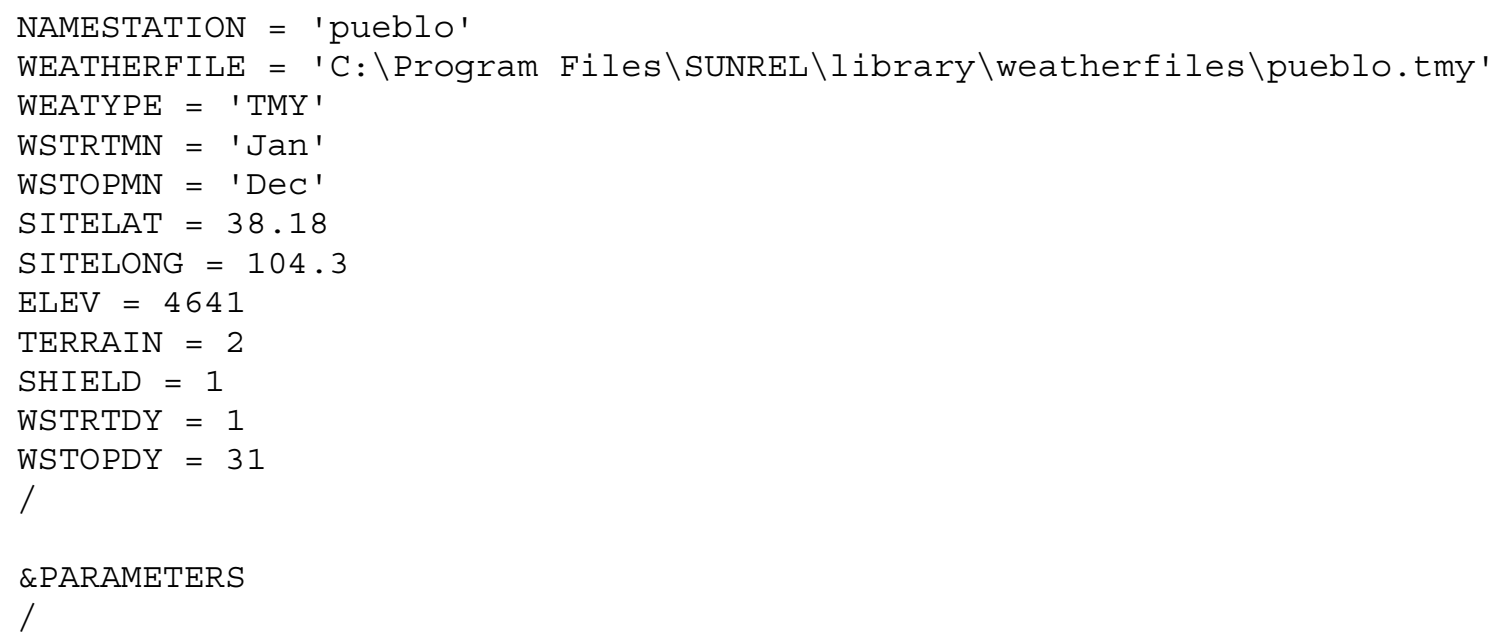




\section{Appendix G-Data-Logger Program and Sample Data Record}

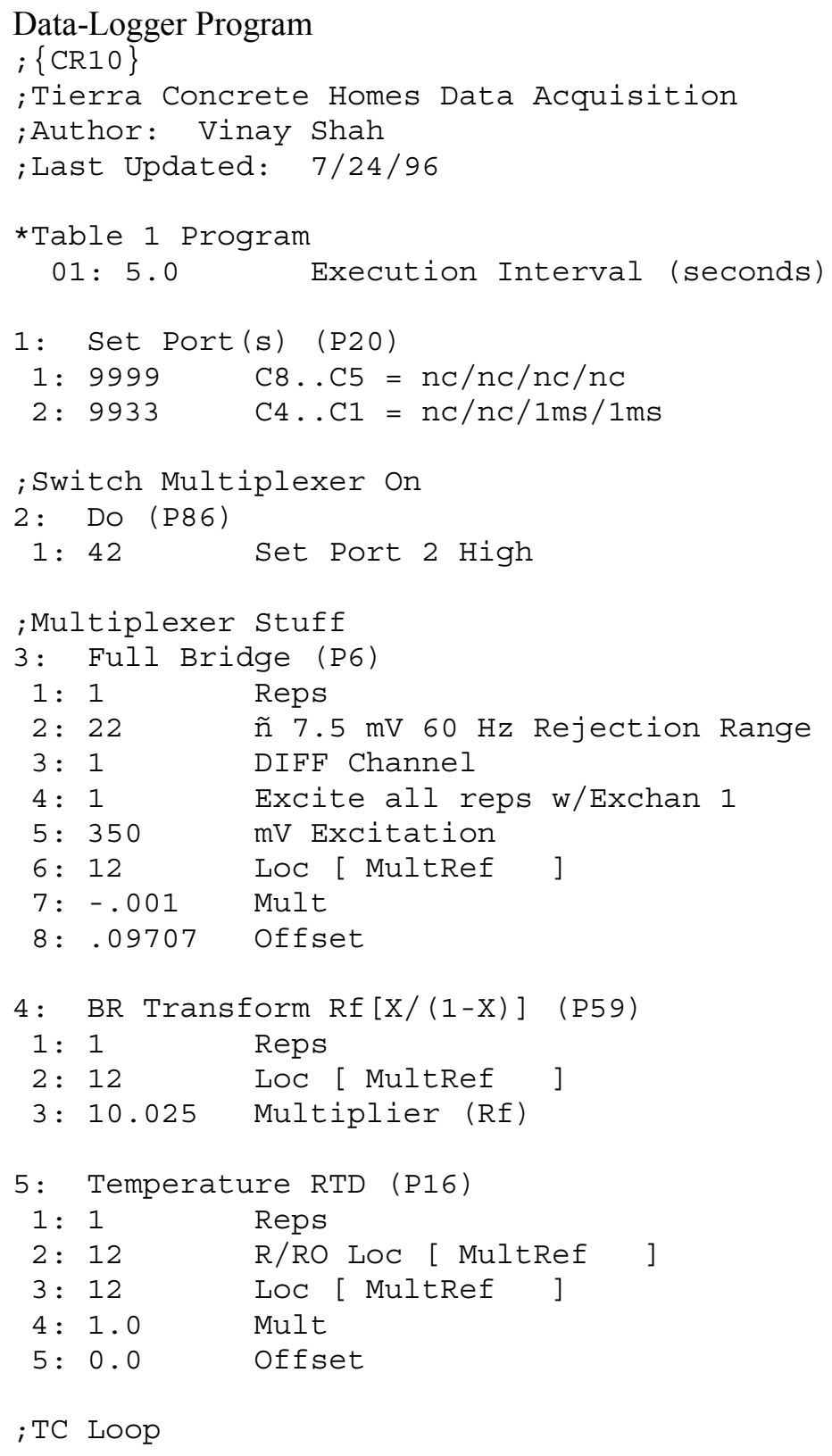




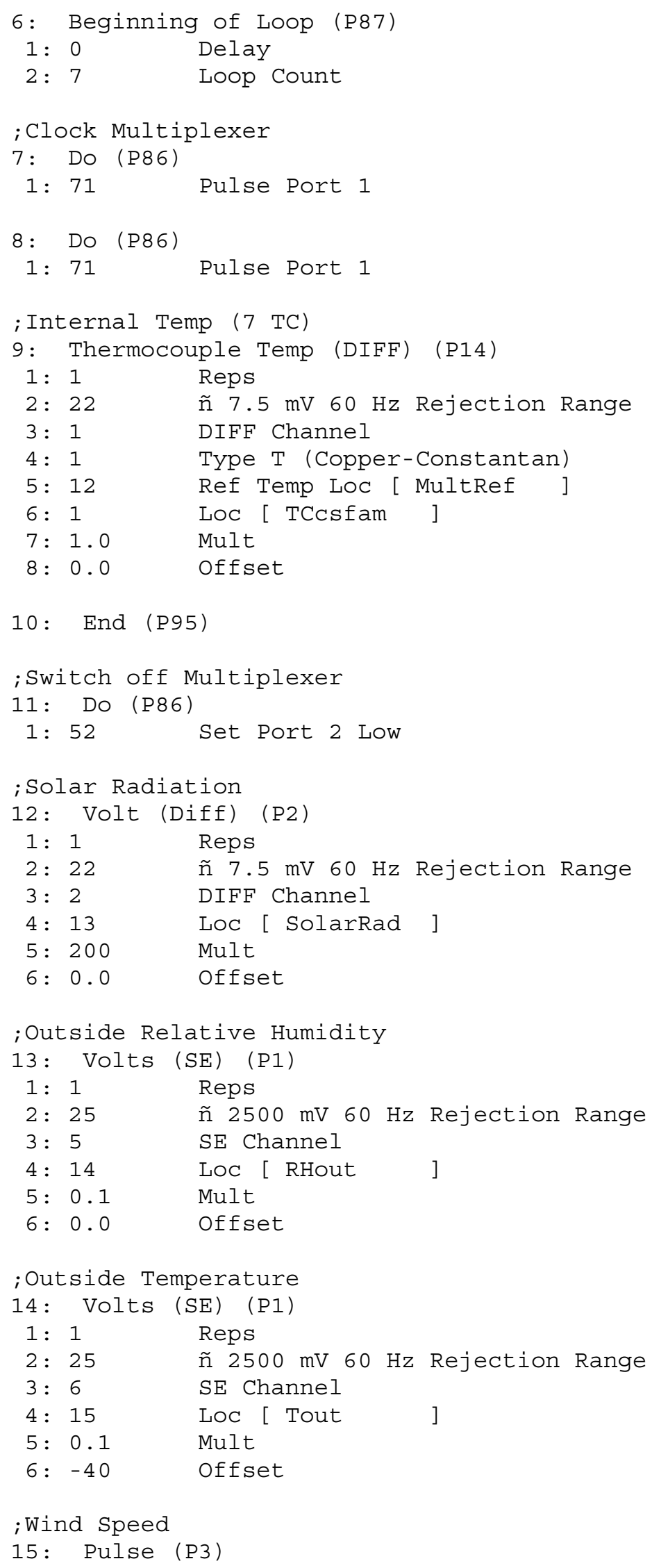




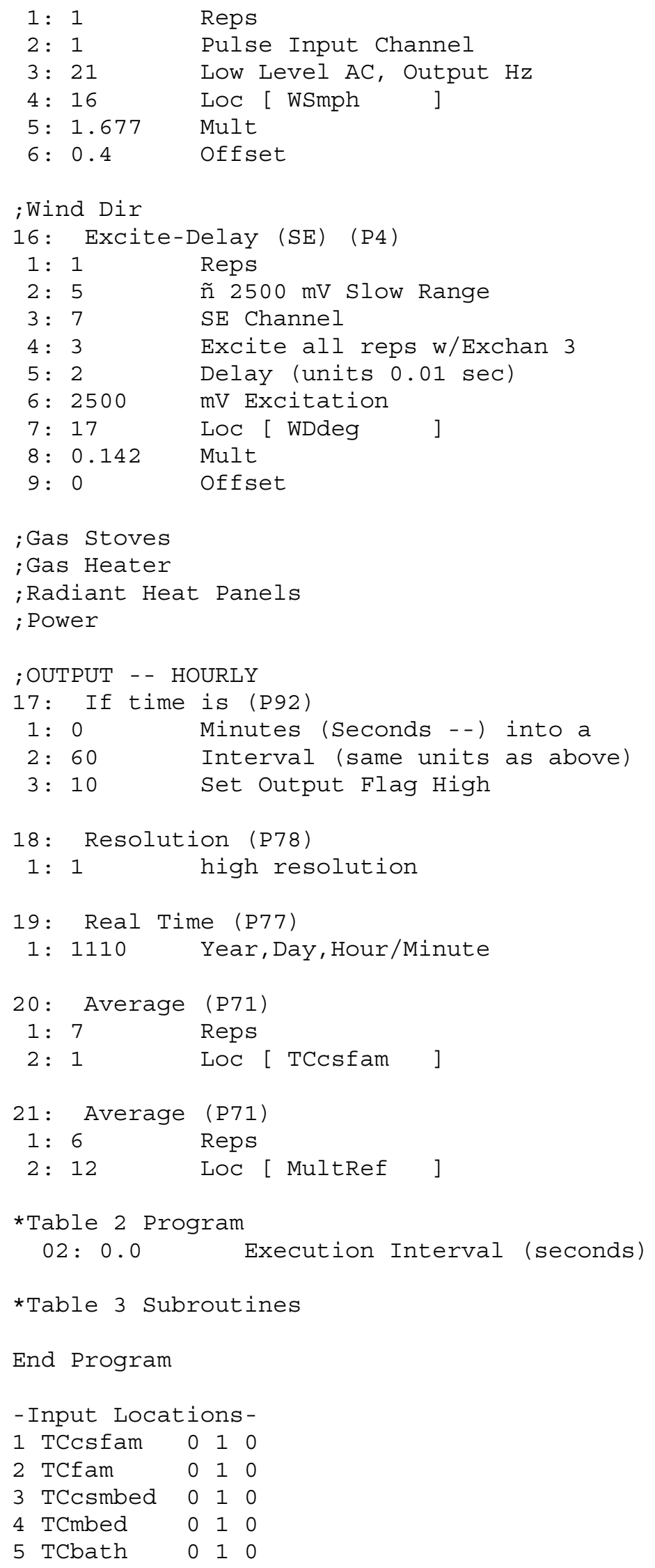




\begin{tabular}{|c|c|c|c|c|}
\hline & TCbed & 01 & 0 & \\
\hline 7 & rcaryer & 01 & 0 & \\
\hline 8 & ГC8 & 00 & 0 & \\
\hline & ГC9 & 00 & 0 & \\
\hline 10 & TC10 & 0 & 0 & 0 \\
\hline 11 & TC11 & 0 & 0 & 0 \\
\hline 12 & MultRef & 0 & 4 & 3 \\
\hline 13 & SolarRad & 2 & 1 & 1 \\
\hline 14 & RHout & 2 & 2 & 1 \\
\hline 15 & Tout & 2 & 2 & 1 \\
\hline 16 & WSmph & 2 & 2 & 1 \\
\hline 17 & WDdeg & 2 & 2 & 1 \\
\hline 18 & & 2 & 1 & 0 \\
\hline 19 & & 2 & 1 & 0 \\
\hline 20 & & 2 & 0 & 0 \\
\hline 21 & & 2 & 0 & 0 \\
\hline 22 & & 2 & 0 & 0 \\
\hline 23 & & 2 & 0 & 0 \\
\hline 24 & & 2 & 0 & 0 \\
\hline 25 & & 2 & 0 & 0 \\
\hline 26 & & 2 & 0 & 0 \\
\hline 27 & & 2 & 0 & 0 \\
\hline 28 & & 2 & 0 & 0 \\
\hline 29 & & 2 & 0 & 0 \\
\hline 30 & & 2 & 0 & 0 \\
\hline 31 & 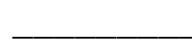 & 2 & 0 & 0 \\
\hline & $\begin{array}{l}\text { rogram Sec } \\
00\end{array}$ & curi & ty & \\
\hline 00 & & & & \\
\hline & & & & \\
\hline & $\begin{array}{l}\text { ode } 4- \\
\text { inal Stora }\end{array}$ & age & & ea 2 \\
\hline
\end{tabular}

\section{$\underline{\text { Sample Data Record }}$}

$\{$ blank 1 ine $\}$
$112,1996,204,1430,21.401,21.986,22.33$
$112,1996,204,1430,21.381,22.357,22.778$
$112,1996,204,1435,21.363,21,21.195$
$113,1996,204,1440,21.319,13.235,20.401,20.468$
$113,1996,204,1445,21.306,13.237,20.447,20.497$
$113,1996,204,1450,21.295,13.241,21.375,21.468$
$113,1996,204,1455,21.326,13.242,21.846,21.978$
$113,1996,204,1500,21.372,13.242,21.979,22.117$
$113,1996,204,1505,21.42,13.244,22.051,22.192$
$113,1996,204,1510,21.469,13.246,22.103,22.244$
$113,1996,204,1515,21.516,13.247,22.145,22.286$
$113,1996,204,1520,21.559,13.249,22.179,22.32$
$113,1996,204,1525,21.6,13.251,22.209,22.348$
$113,1996,204,1530,21.638,13.252,22.236,22.373$
$113,1996,204,1535,21.672,13.254,22.26,22.394$ 


\section{Appendix H-Temperature Profiles and Precipitation Graphs}

$\underline{\text { November and December }}$

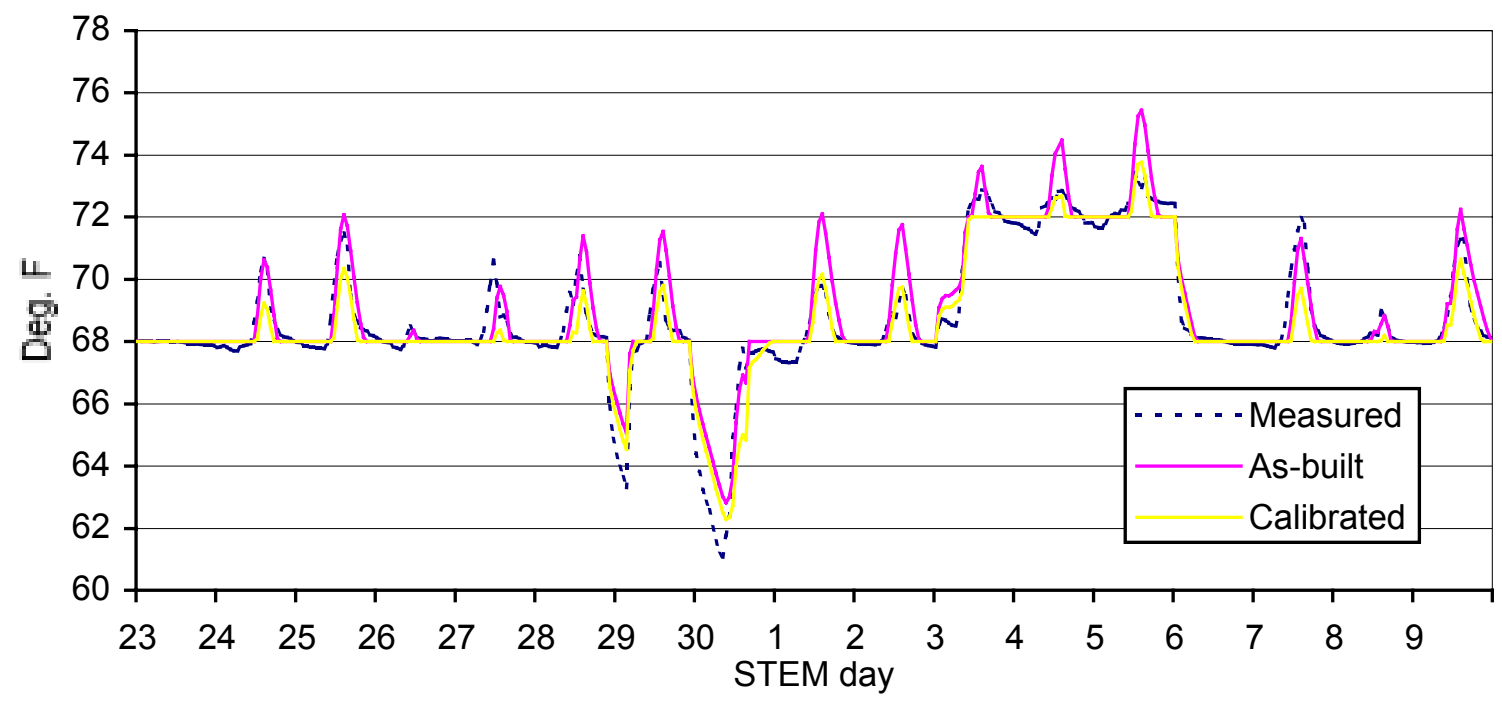

Figure $\mathrm{H} 1$. Measured and modeled indoor temperature profiles during STEM period

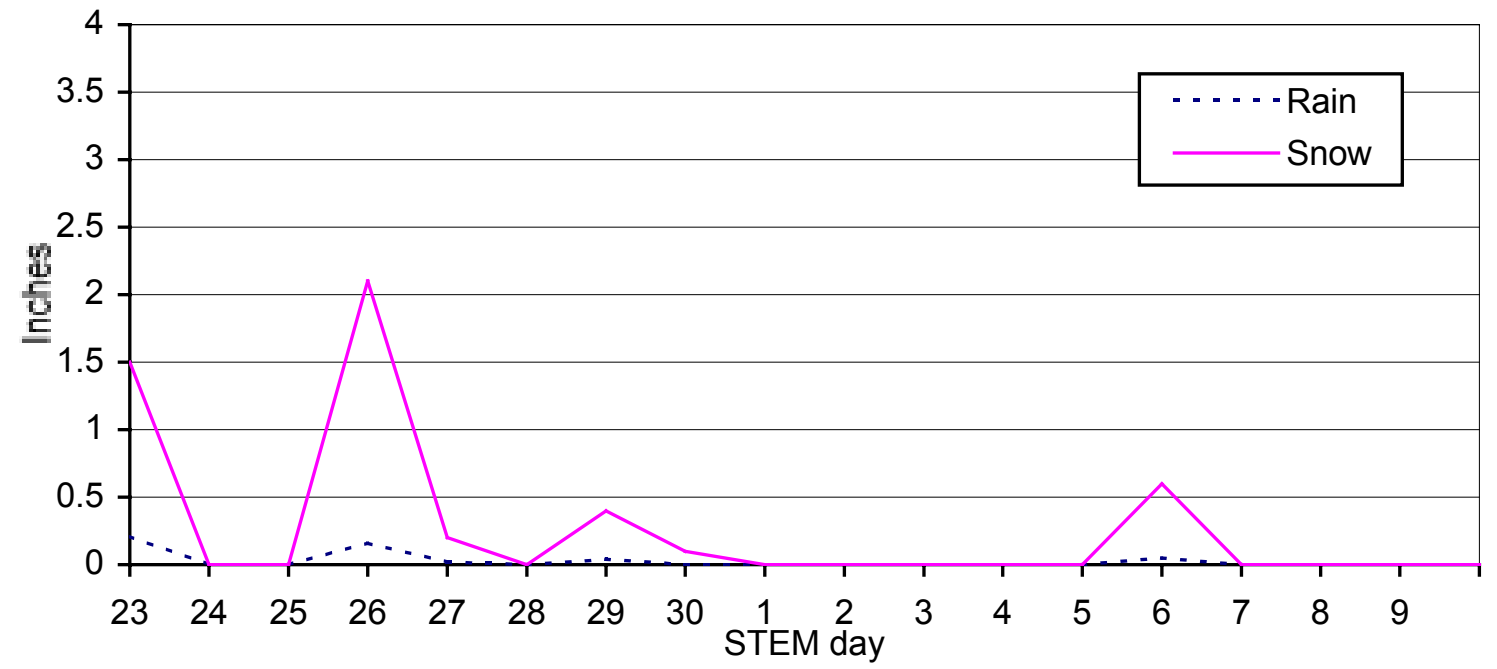

Figure H2. Snow and rainfall levels during STEM period [24] 


\section{$\underline{\text { January }}$}

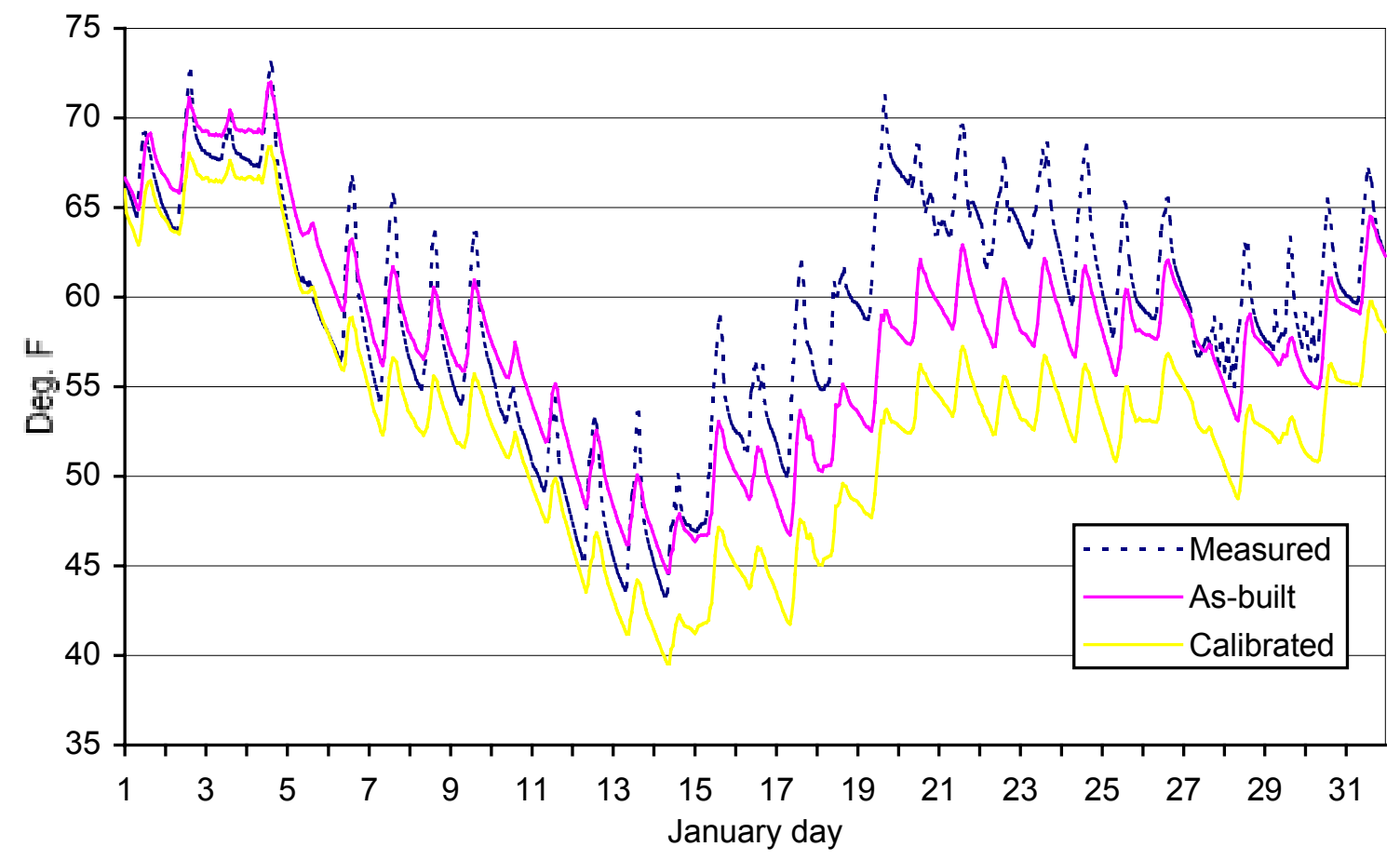

Figure H3. Measured and modeled indoor temperature profiles for January 1997

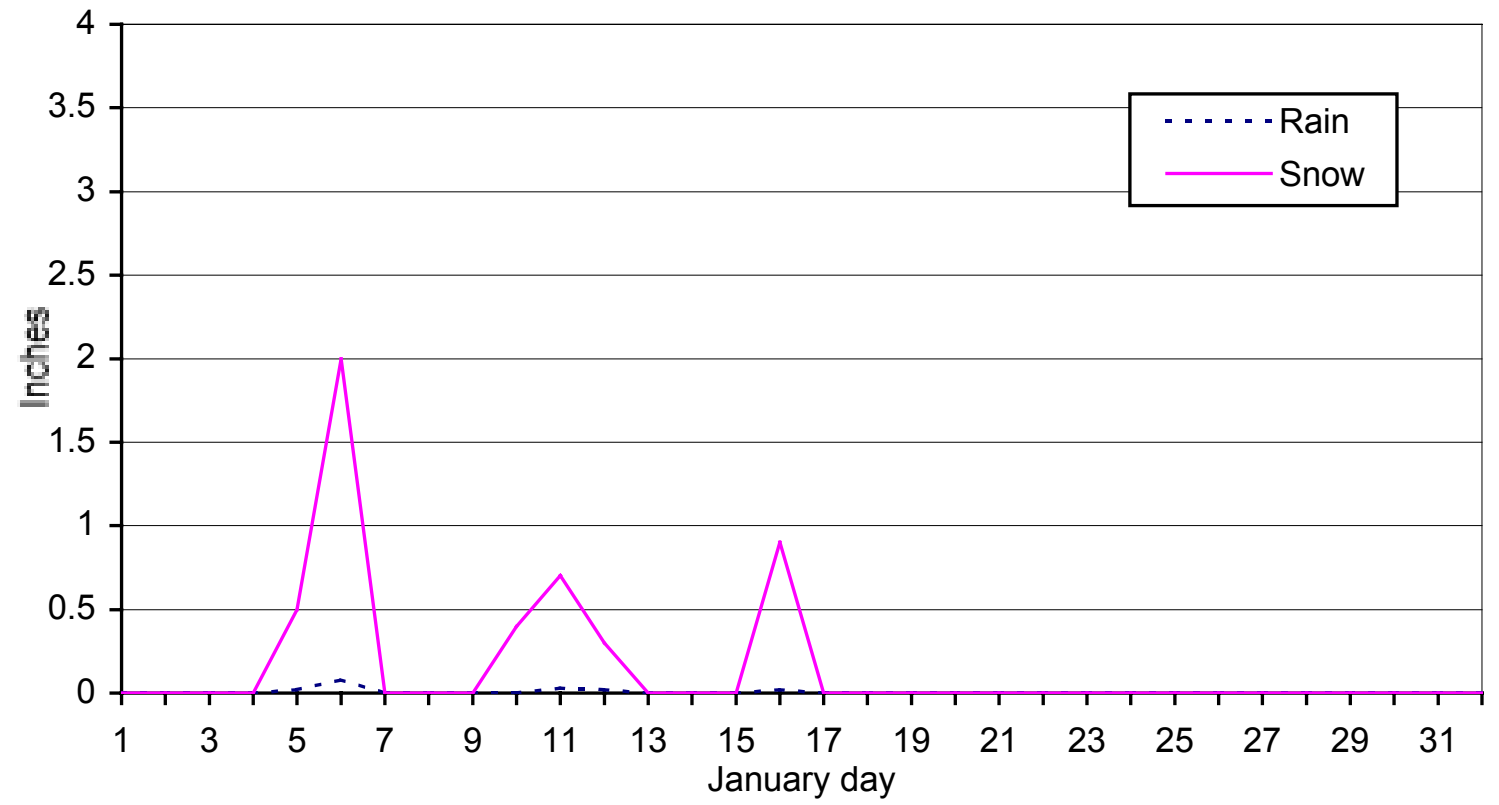

Figure H4. Snow and rainfall levels for January 1997 


\section{February}

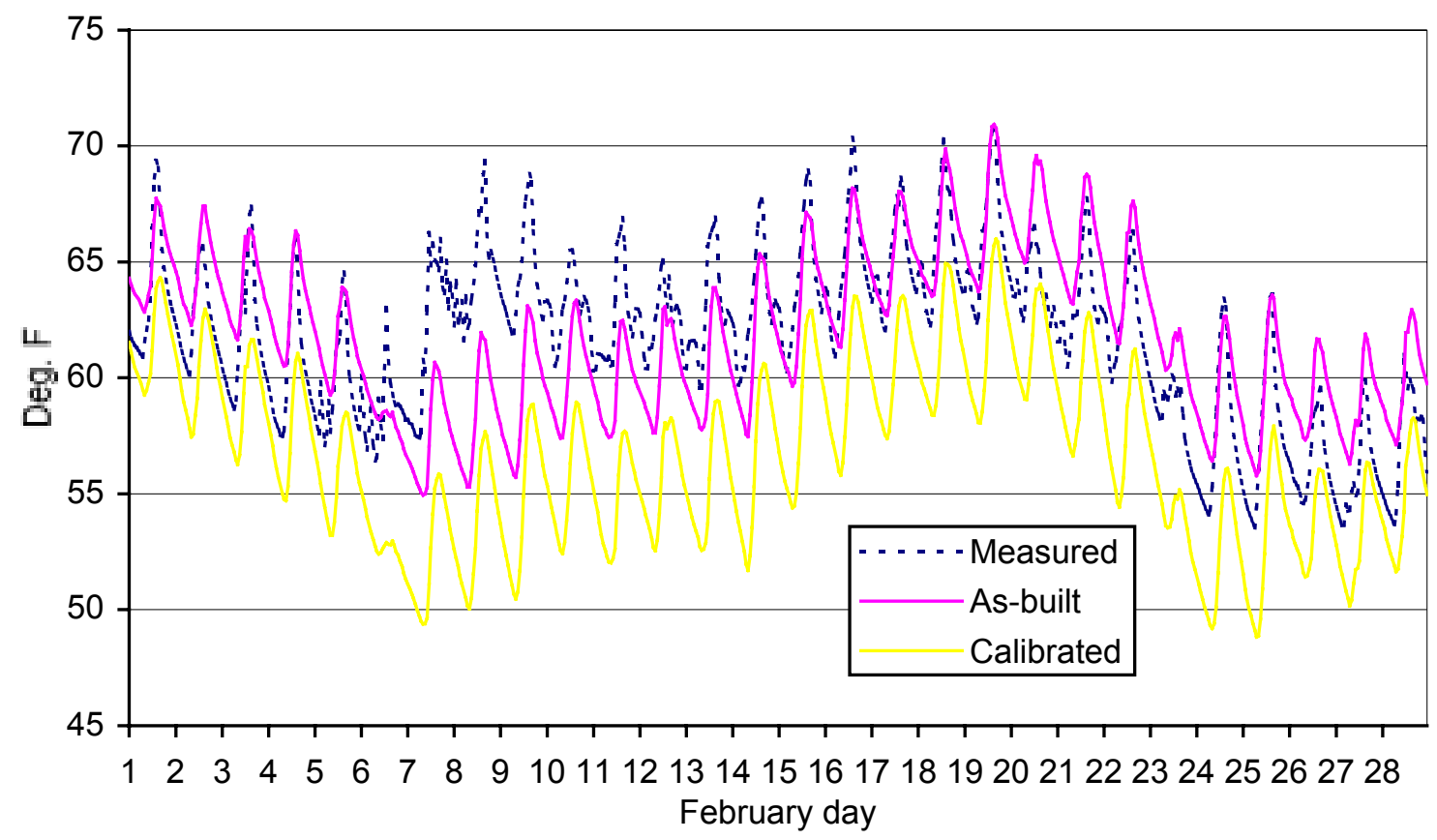

Figure H5. Measured and modeled indoor temperature profiles for February 1997

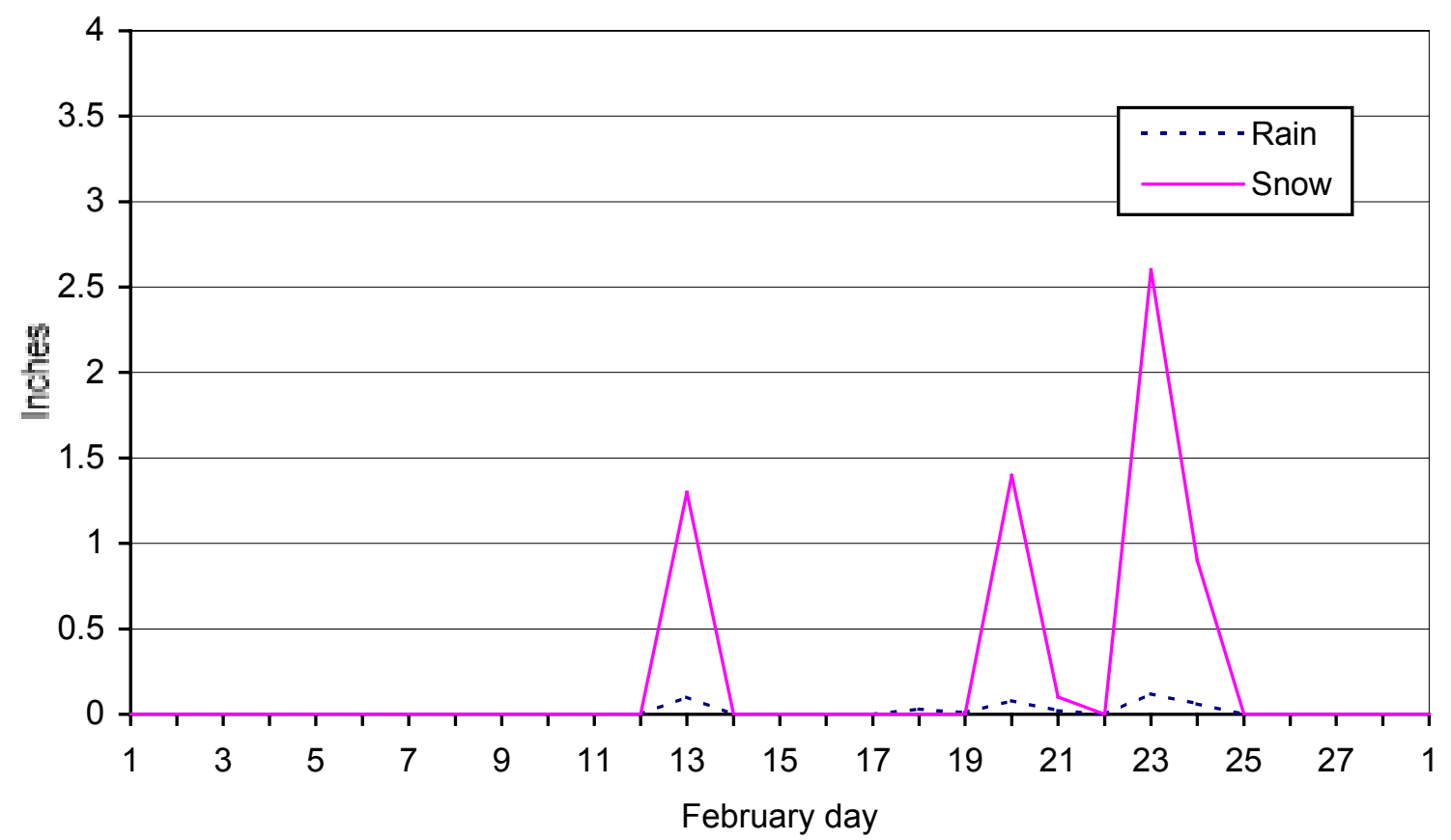

Figure H6. Snow and rainfall levels for February 1997 


\section{$\underline{\text { March }}$}

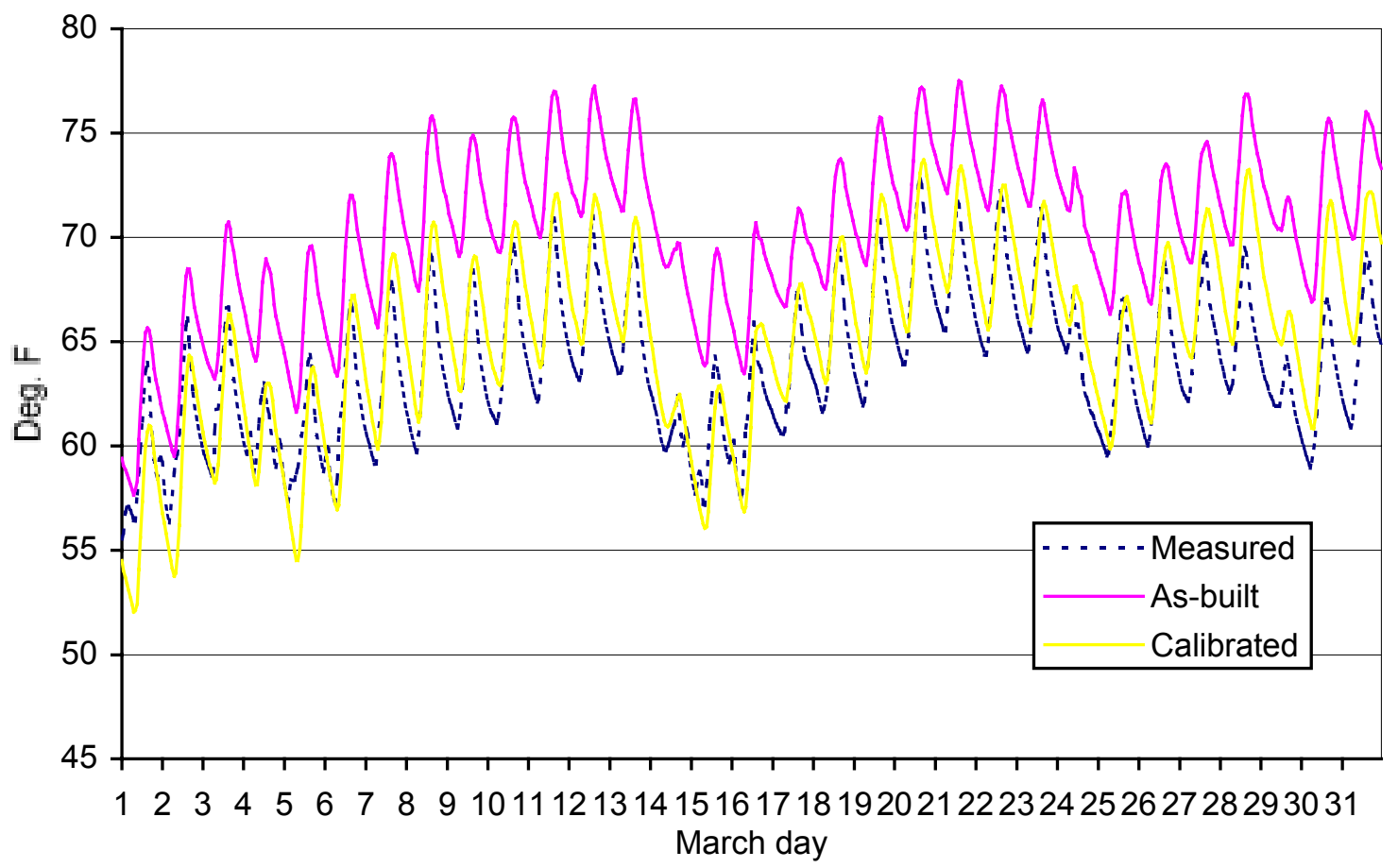

Figure H7. Measured and modeled indoor temperature profiles for March 1997

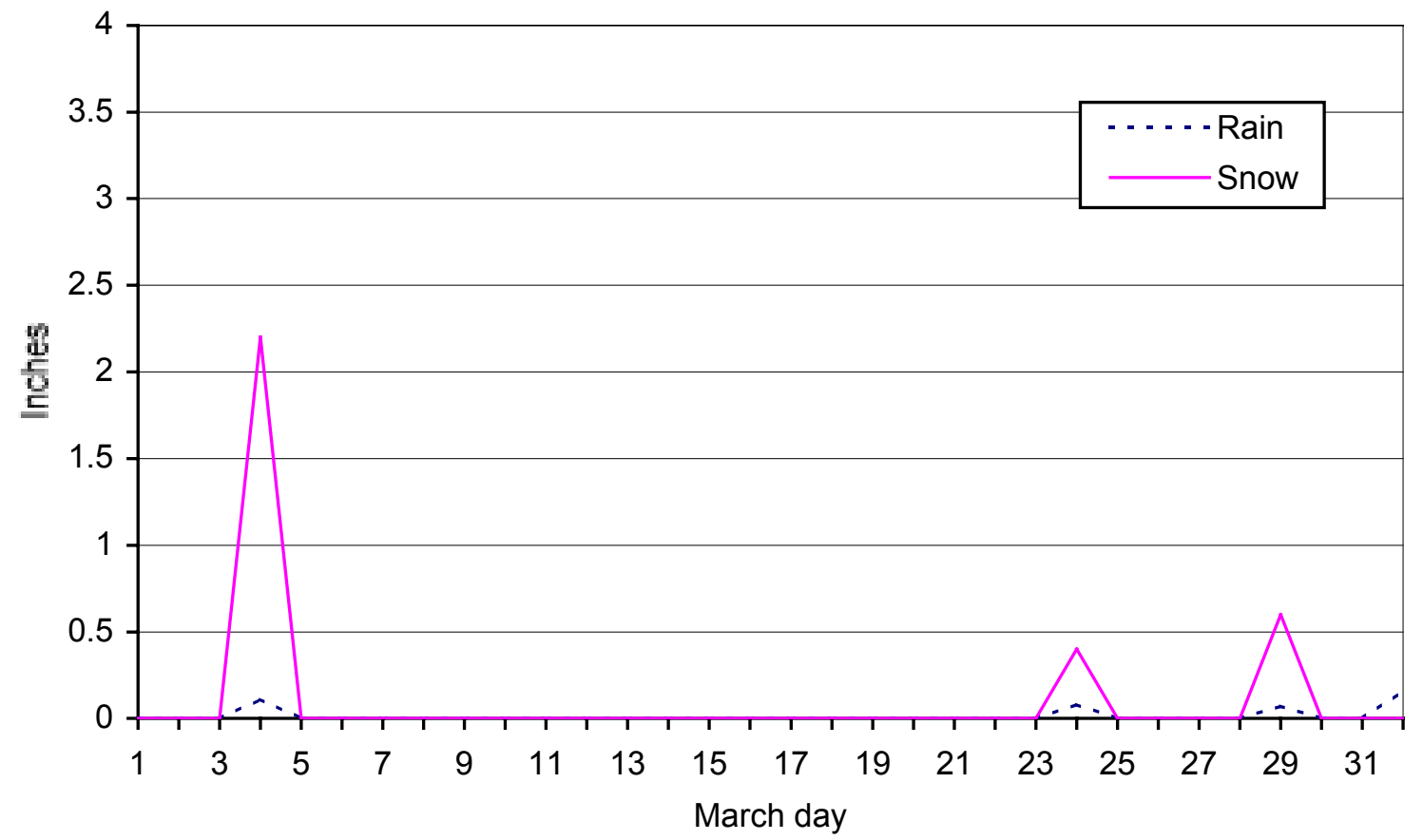

Figure H8. Snow and rainfall levels for March 1997 
April

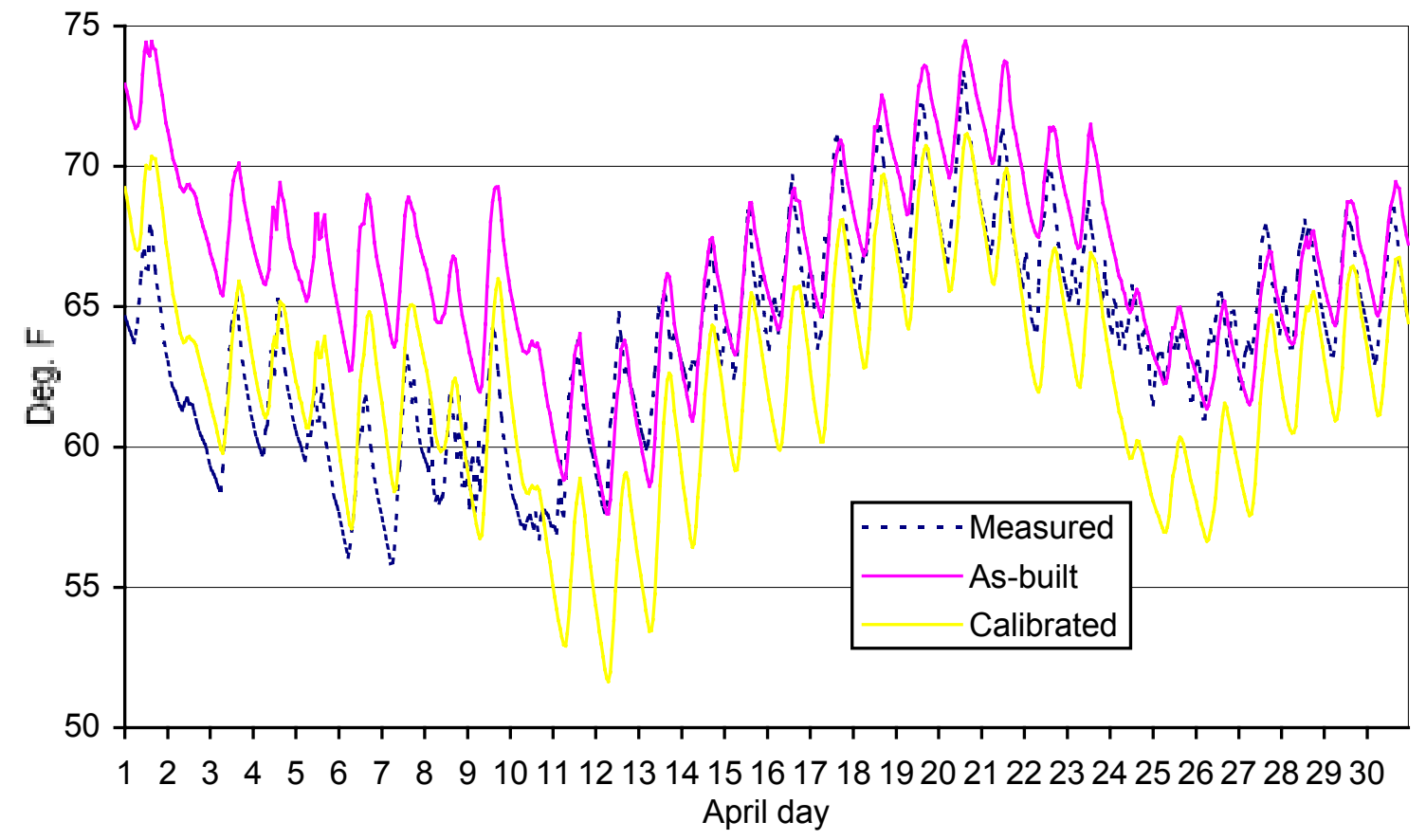

Figure H9. Measured and modeled indoor temperature profiles for April 1997

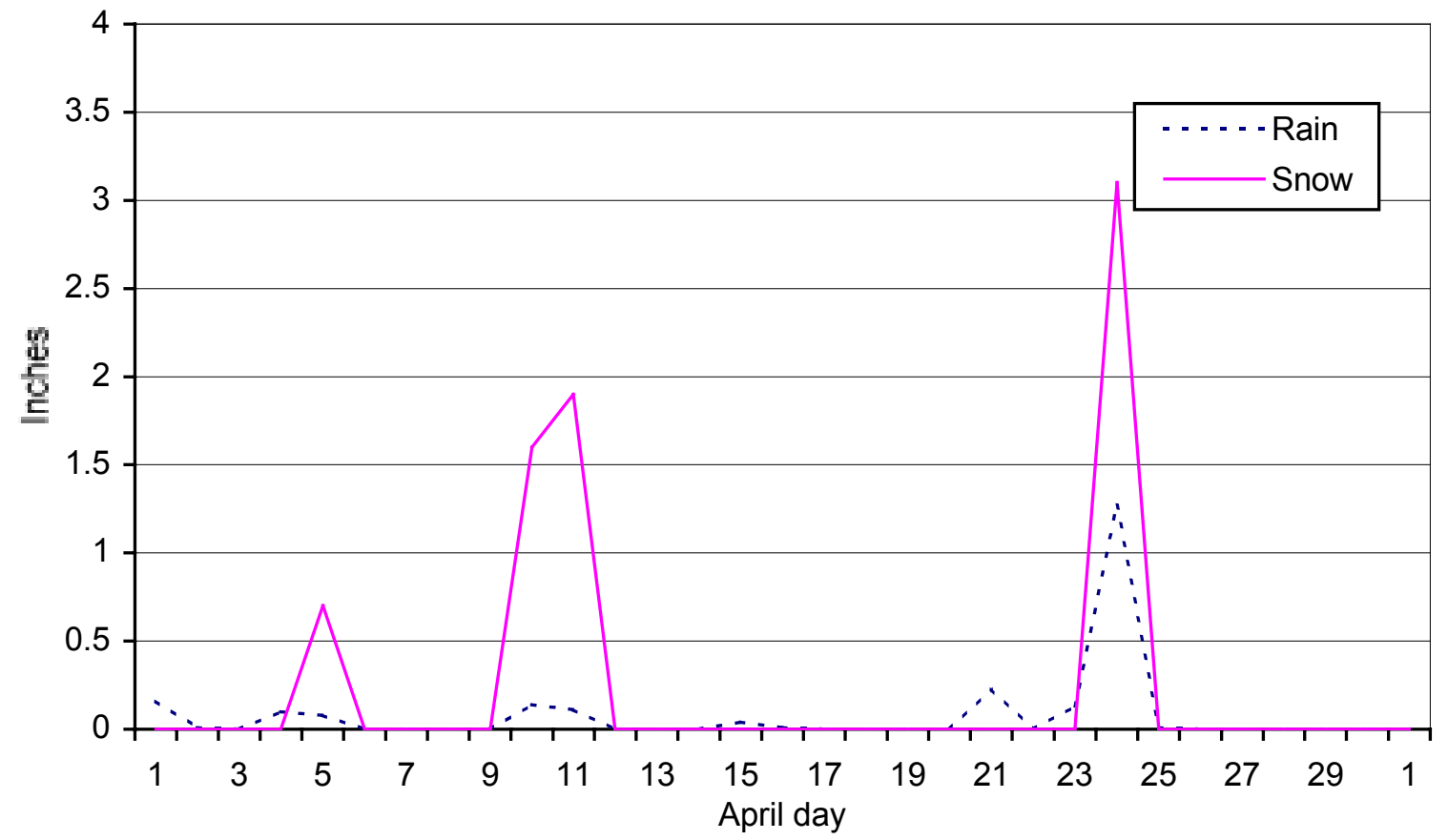

Figure H10. Snow and rainfall levels for April 1997 
$\underline{\text { May }}$

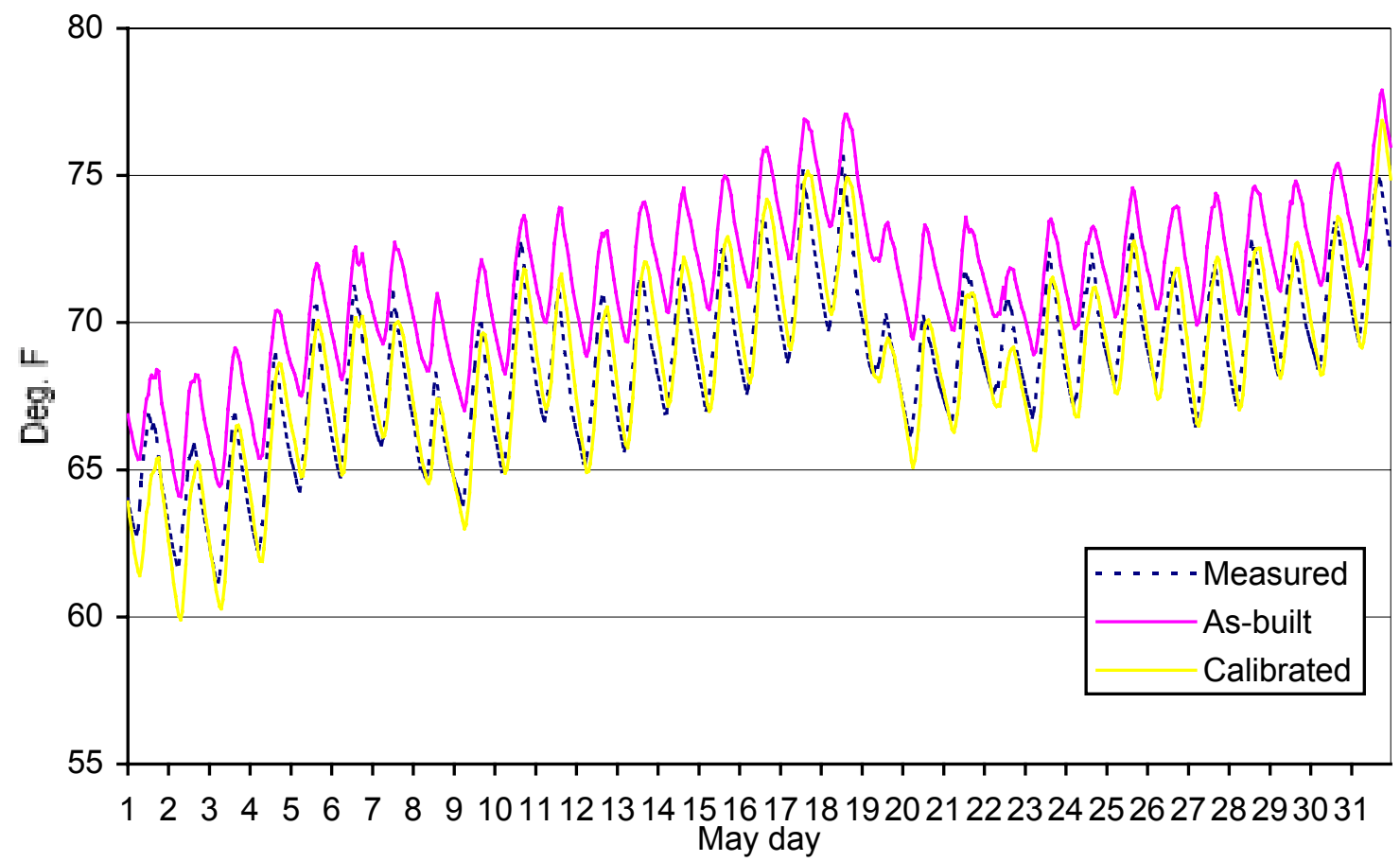

Figure H11. Measured and modeled indoor temperature profiles for May 1997

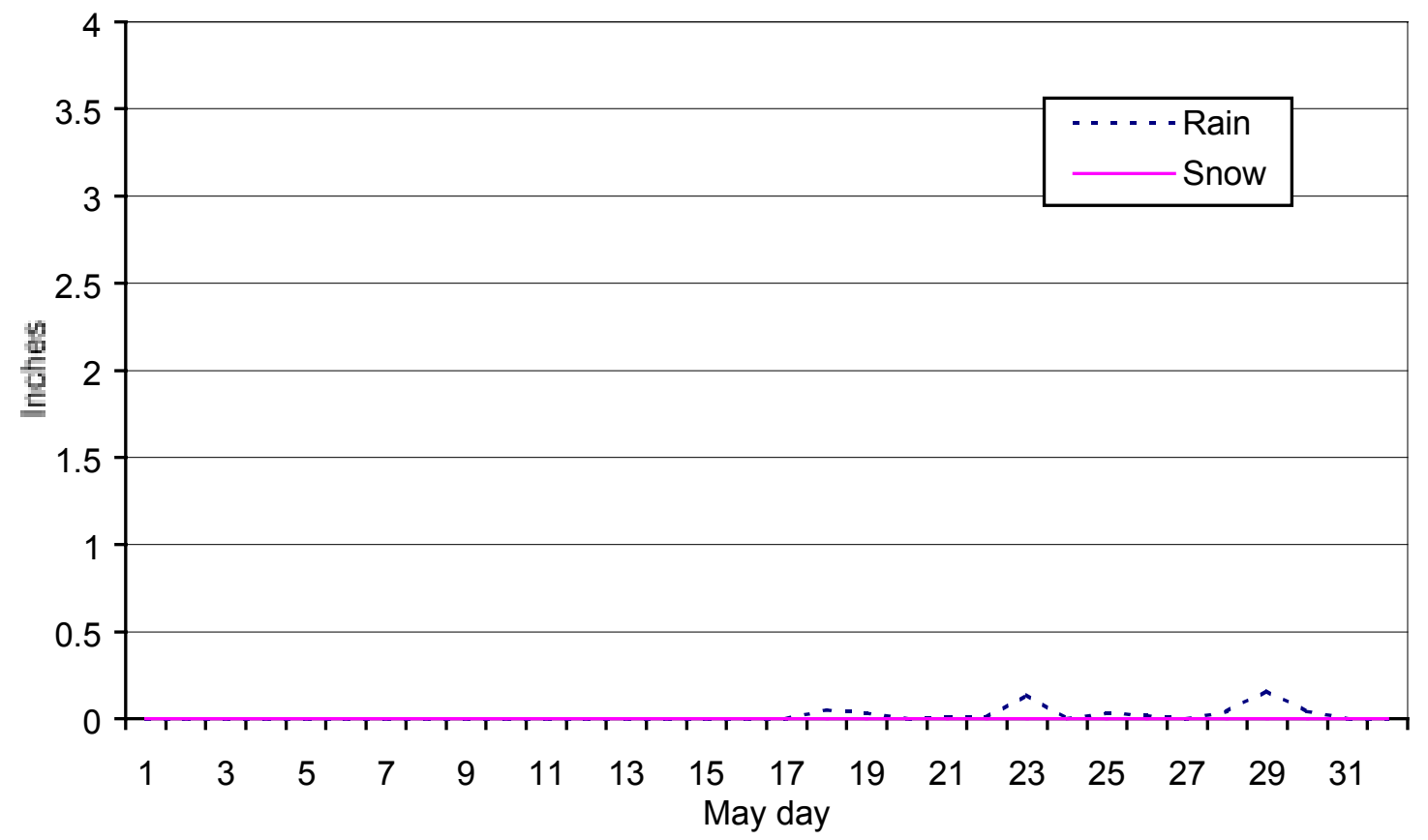

Figure H12. Snow and rainfall levels for May 1997 


\section{June}

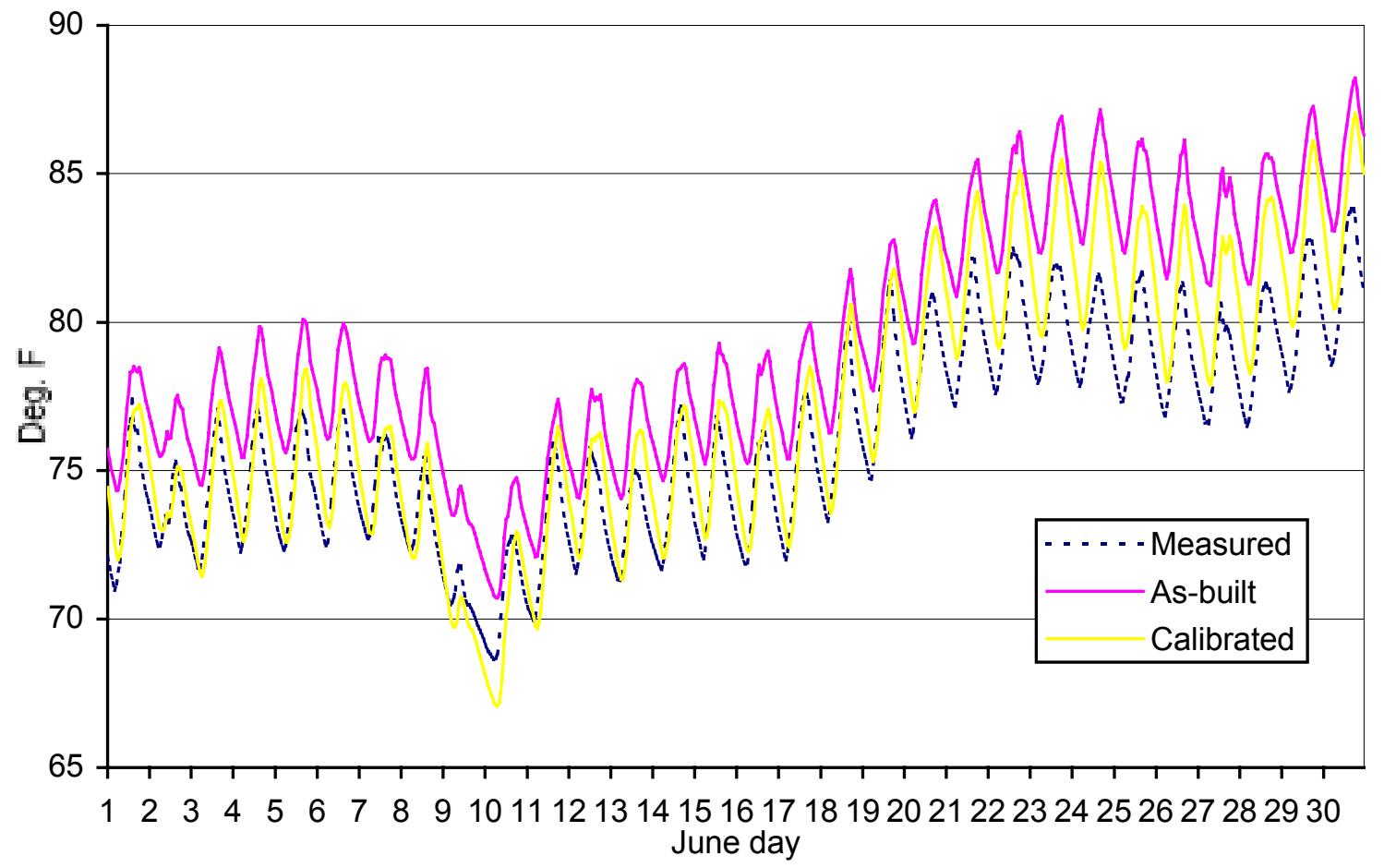

Figure H13. Measured and modeled indoor temperature profiles for June 1997

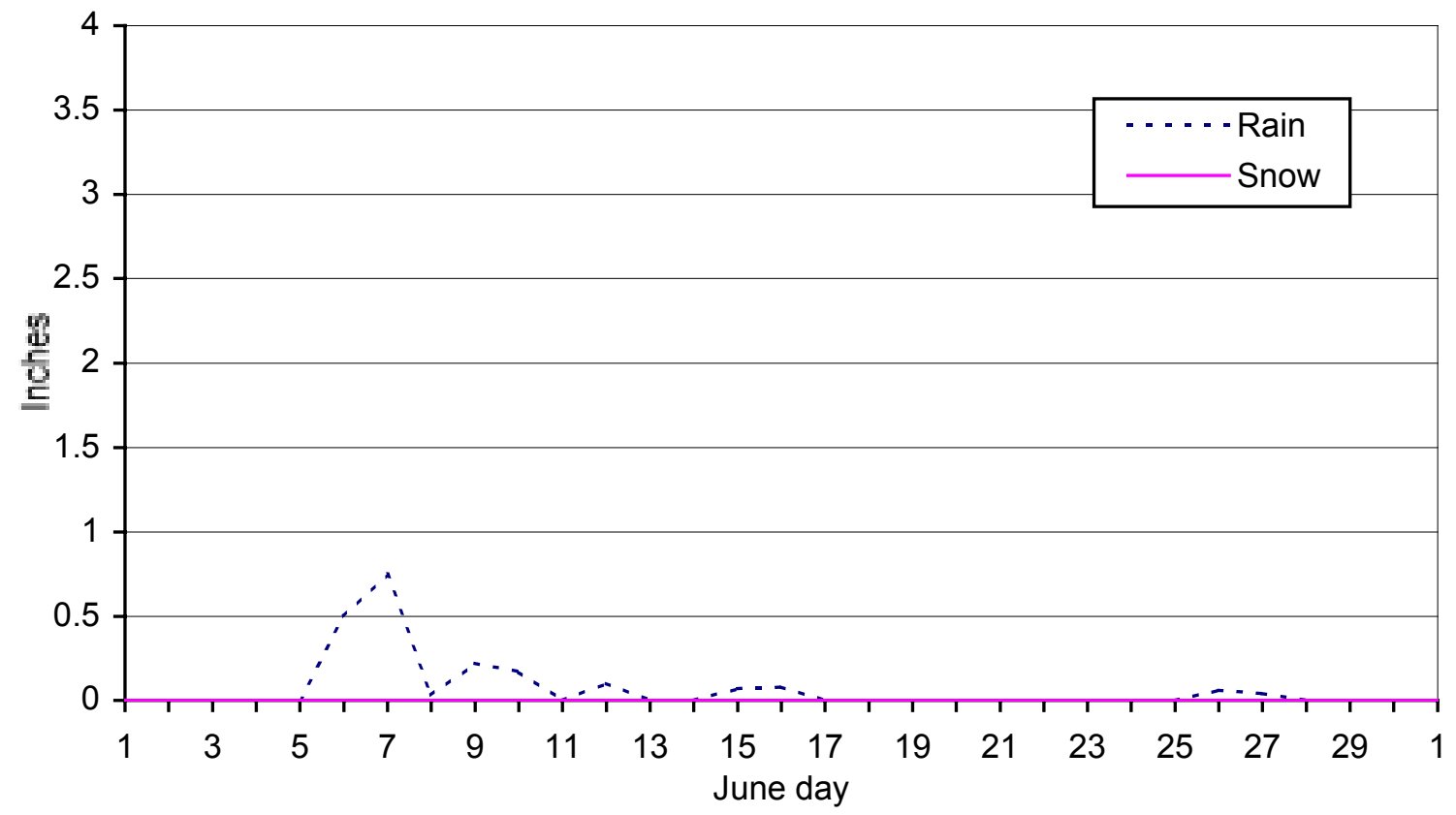

Figure H14. Snow and rainfall levels for June 1997 
$\underline{\text { July }}$

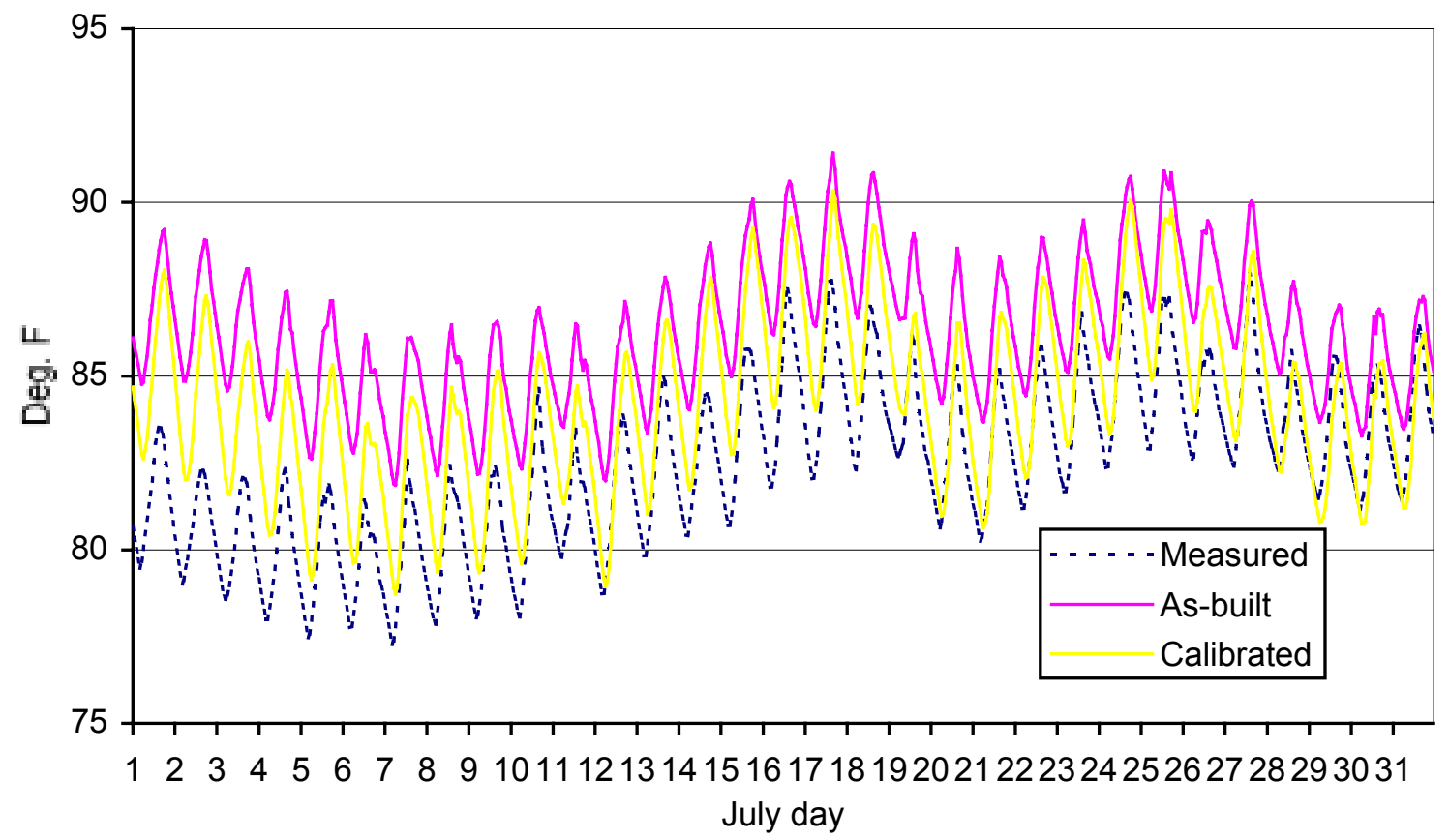

Figure H15. Measured and modeled indoor temperature profiles for July 1997

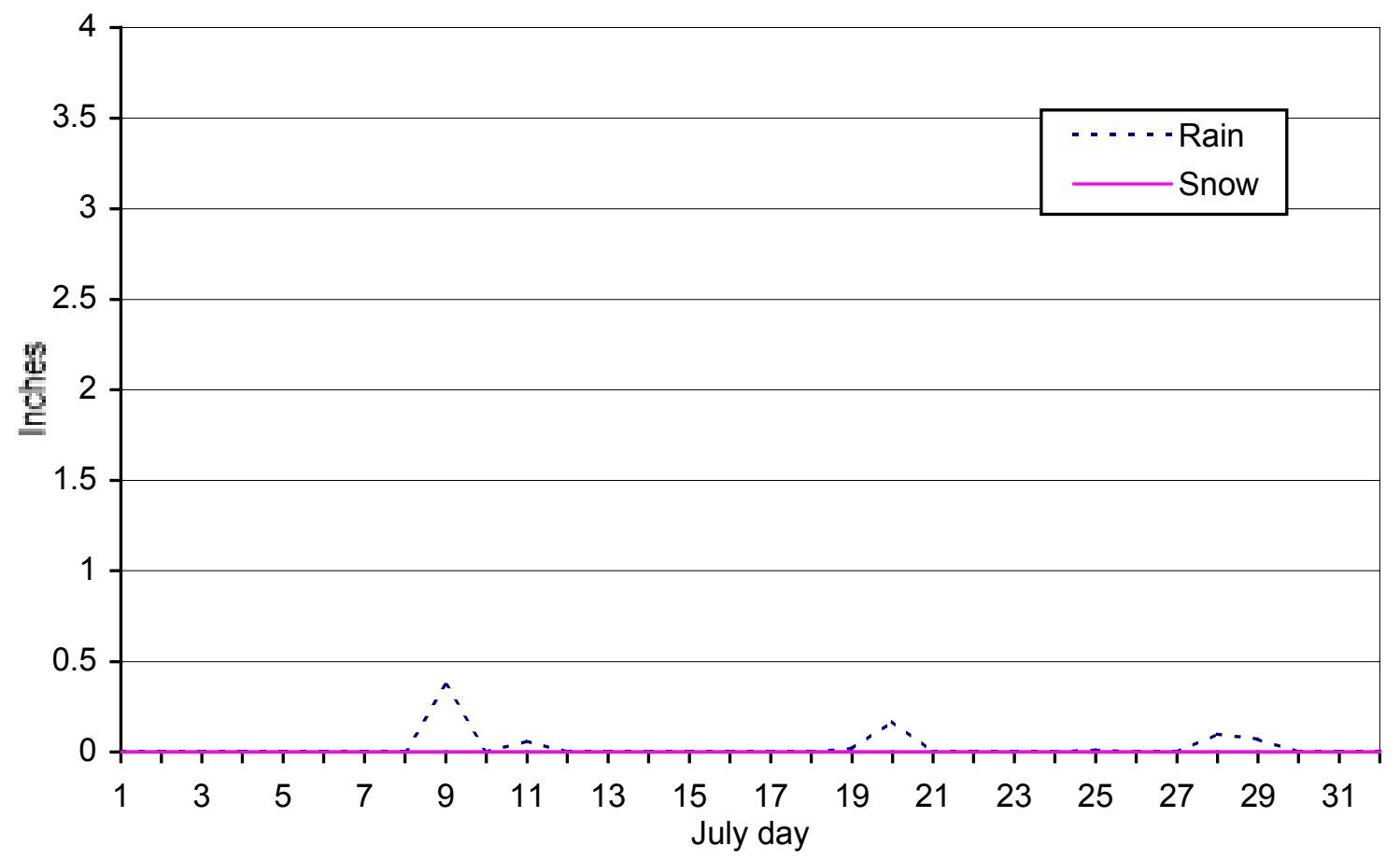

Figure H16. Snow and rainfall levels for July 1997 


\section{$\underline{\text { August }}$}

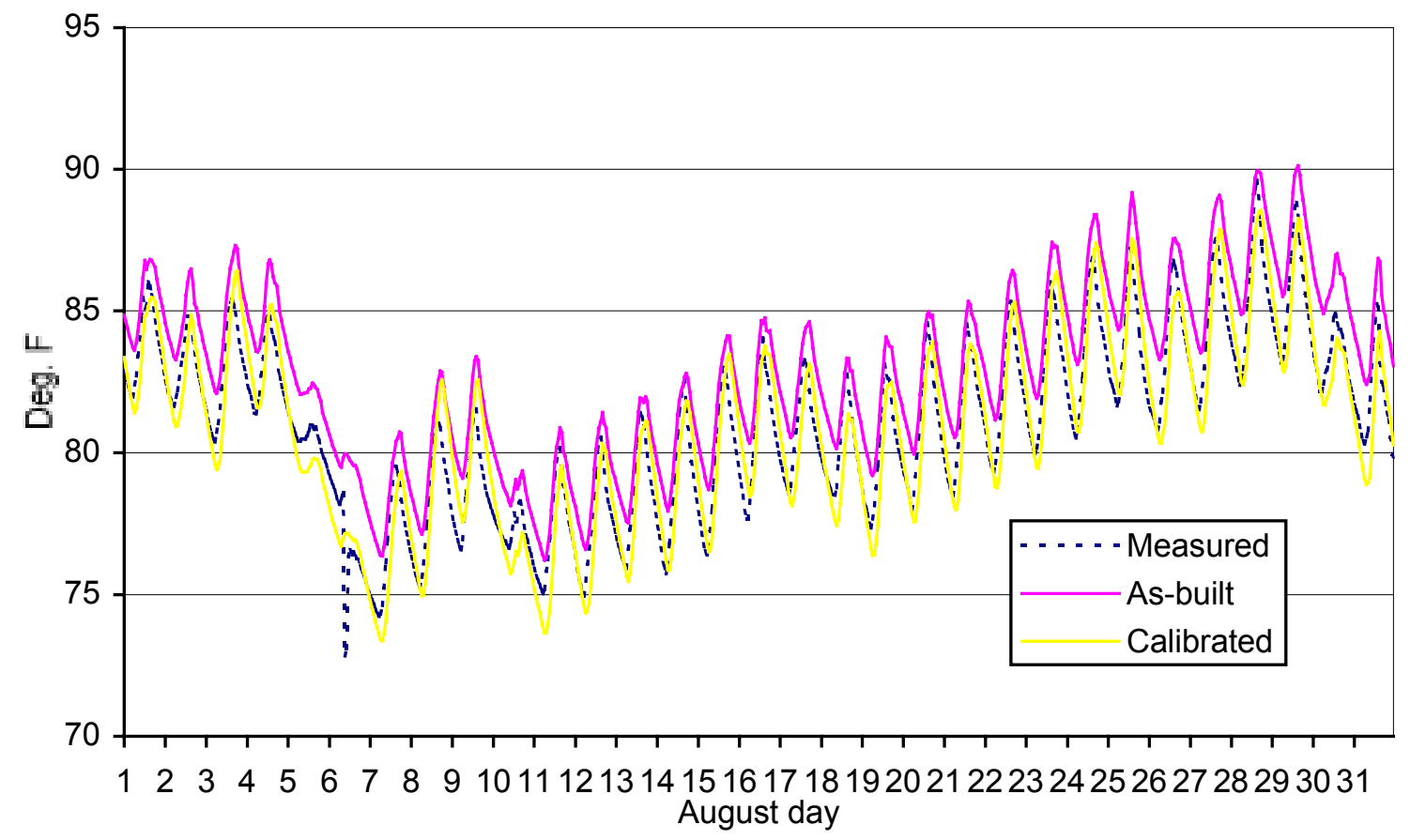

Figure H17. Measured and modeled indoor temperature profiles for August 1997

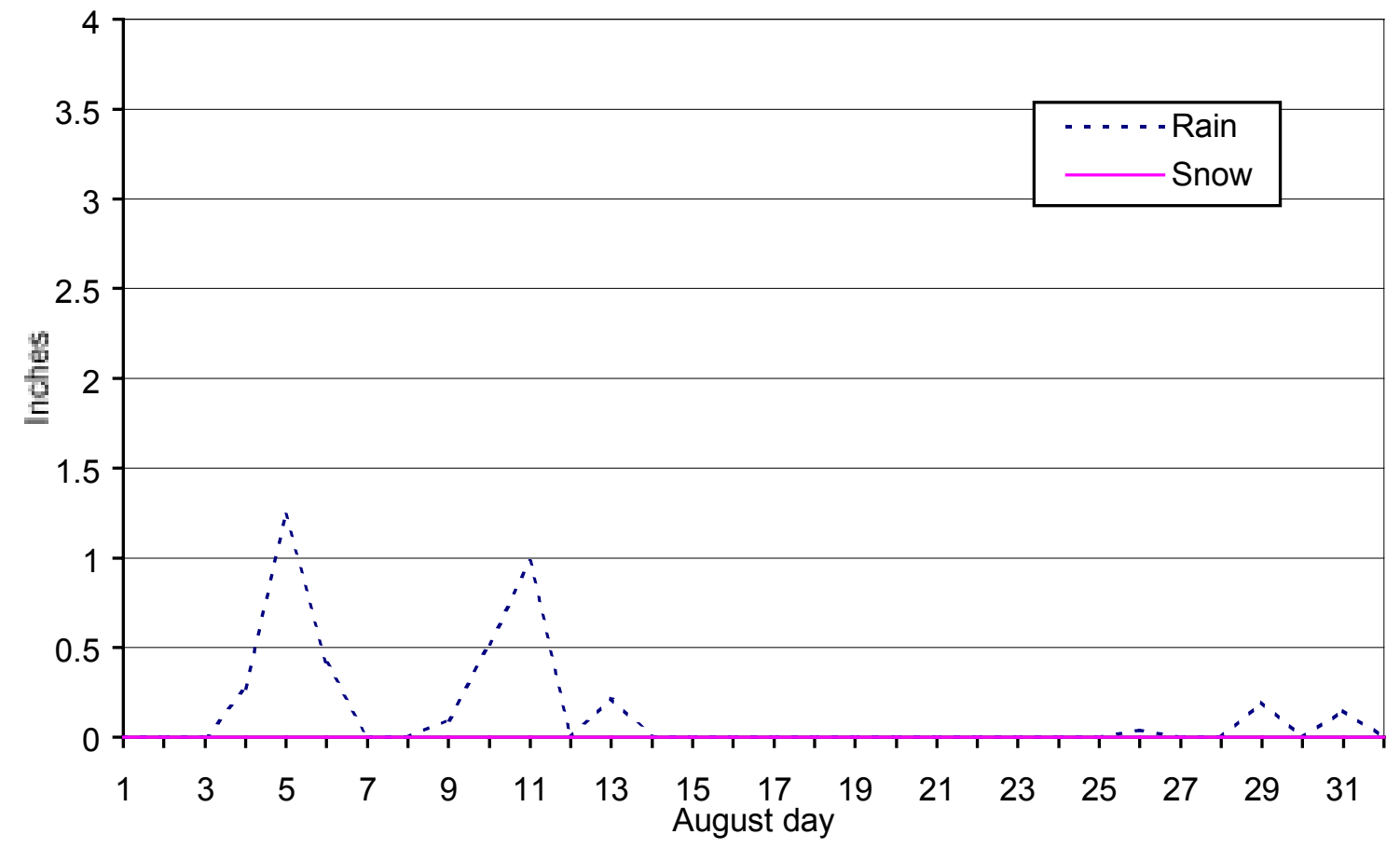

Figure H18. Snow and rainfall levels for August 1997 


\section{$\underline{\text { September }}$}

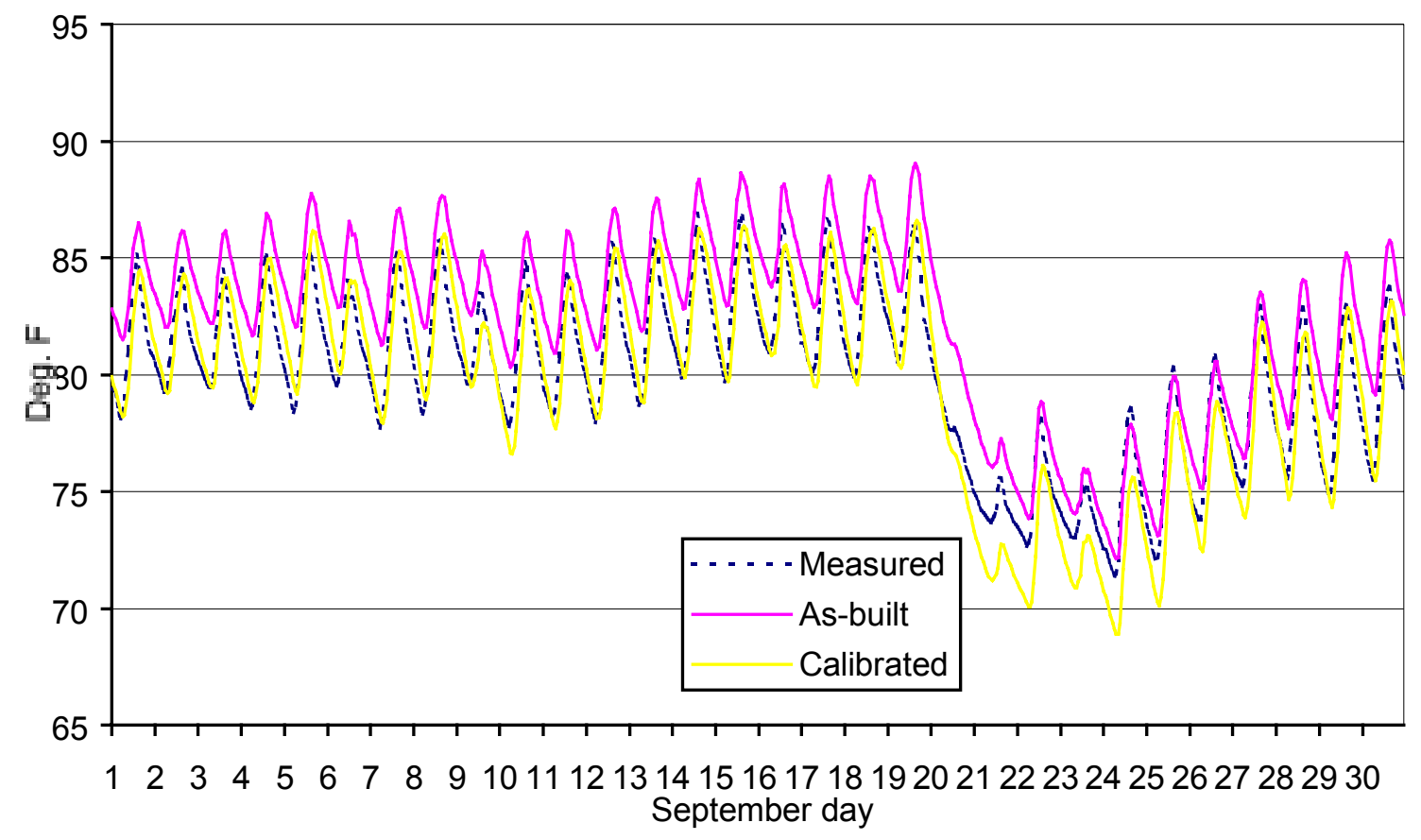

Figure H19. Measured and modeled indoor temperature profiles for September 1997

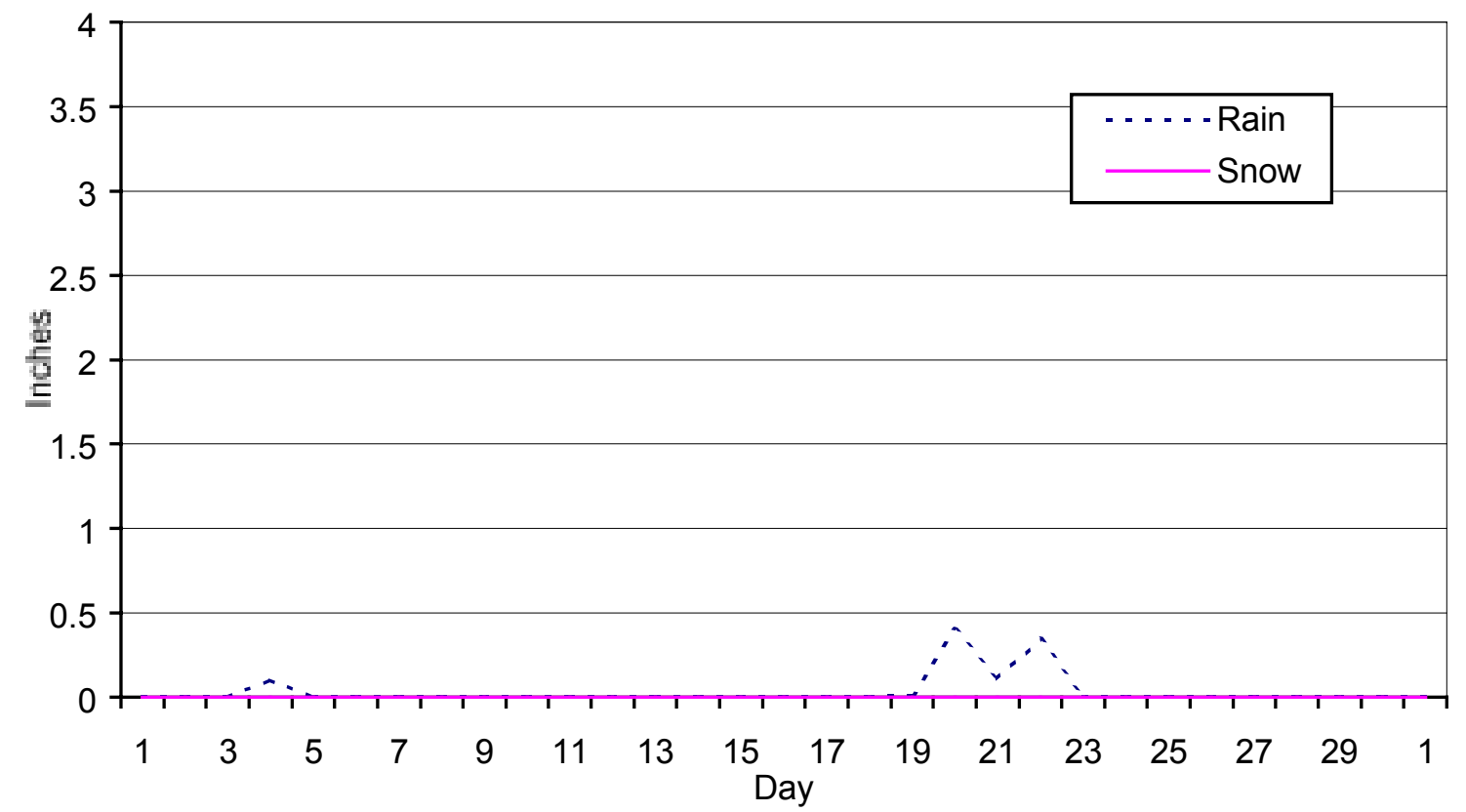

Figure H20. Snow and rainfall levels for September 1997 


\section{Appendix I-Model Descriptions}

Several models that were used in different phases of this project are defined as follows:

Original: The original model is based on plans for an $1,120 \mathrm{ft}^{2}\left(104 \mathrm{~m}^{2}\right)$ house. The design of this house was fine-tuned in the design phase [4], but the house was never built.

Preconstruction: The preconstruction model is based on the $1870 \mathrm{ft}^{2}\left(174 \mathrm{~m}^{2}\right)$ plans of Tierra I prior to construction. Most of the preliminary analysis of Tierra I was done using this model.

As-built: The as-built model reflects changes to the plans that occurred during construction. Little analysis is done using this model.

Calibrated: The as-built model was calibrated to match short- and long-term performance data. The calibrated model provides a more accurate model of the house.

Improved: The calibrated model was improved to try to meet the $70 \%$ savings requirements. The improved model uses increased quantities of insulation and south-glazing area while maintaining the changes to material properties assumed in the calibration process.

Base case: The base case model conforms to HERS/MEC specifications. There was one base case $\left(1,120 \mathrm{ft}^{2}\right)$ in the design report and a new one in this report that was redone to match the size of Tierra $\mathrm{I}\left(1,870 \mathrm{ft}^{2}\right)$. 


\section{Appendix J-ELA and ACH Calculations}

ELA calculation

From Figure 17 the airflow rate at $4 \mathrm{~Pa}$ is $220 \mathrm{cfm} . \mathrm{ELA}=220 \mathrm{cfm} \times 0.2835=62.37 \mathrm{in}^{2}$.

ACH calculation [blower door manual]

House volume $=19448 \mathrm{ft}^{3}$

CFM50 $=1049.45$ (from measured blower door data)

$\mathrm{ACH} 50=(\mathrm{CFM} 50 * 60) /$ volume $=3.24$

$\mathrm{ACH}=\mathrm{ACH} 50 / \mathrm{N}=0.2039$

$\mathrm{N}=\mathrm{C} \times \mathrm{H} \times \mathrm{S} \times \mathrm{L}=15.876$

$\mathrm{C}=14$

$\mathrm{H}=0.9$

$\mathrm{S}=0.9$

$\mathrm{L}=1.4$

Table J1. Blower Door Data

\begin{tabular}{|r|r|r|r|}
\hline $\begin{array}{c}\text { House Pressure } \\
\mathrm{Pa}\end{array}$ & $\begin{array}{c}\text { Fan Pressure } \\
\mathrm{Pa}\end{array}$ & Ring & Flow ${ }^{*}$ \\
\hline 60 & 48 & $\mathrm{~A}$ & 1226.98 \\
\hline 50 & 35 & $\mathrm{~A}$ & 1049.45 \\
\hline 44 & 32 & $\mathrm{~A}$ & 1003.94 \\
\hline 35 & 23 & $\mathrm{~A}$ & 852.59 \\
\hline 34 & 282 & $\mathrm{~B}$ & 996.43 \\
\hline 30 & 234 & $\mathrm{~B}$ & 906.58 \\
\hline 26 & 205 & $\mathrm{~B}$ & 847.81 \\
\hline 23 & 172 & $\mathrm{~B}$ & 775.70 \\
\hline 21 & 141 & $\mathrm{~B}$ & 701.42 \\
\hline 20 & 114 & $\mathrm{~B}$ & 629.82 \\
\hline 15 & 73 & $\mathrm{~B}$ & 502.54 \\
\hline 34 & 230 & $\mathrm{~B}$ & 898.69 \\
\hline 29 & 215 & $\mathrm{~B}$ & 868.51 \\
\hline 27 & 192 & $\mathrm{~B}$ & 820.14 \\
\hline 27 & 162 & $\mathrm{~B}$ & 752.52 \\
\hline 22 & 125 & $\mathrm{~B}$ & 659.90 \\
\hline 19 & 91 & $\mathrm{~B}$ & 561.89 \\
\hline 15 & 56 & $\mathrm{~B}$ & 439.39 \\
\hline
\end{tabular}

* Calculated using formulas from Blower Door System Manual [25] 


\section{REPORT DOCUMENTATION PAGE}

Form Approved OMB NO. 0704-0188

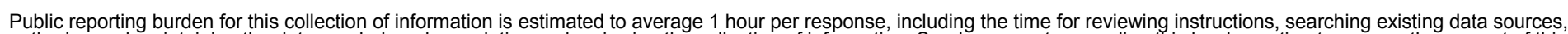

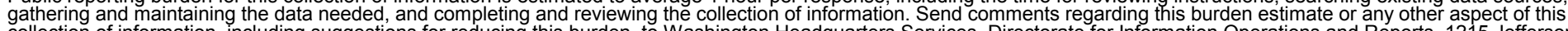

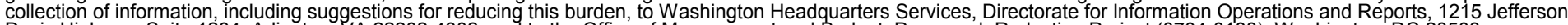
Davis Highway, Suite 1204, Arlington, VA 22202-4302, and to the Office of Management and Budget, Paperwork Reduction Project (0704-0188), Washington, DC 20503.
1. AGENCY USE ONLY (Leave blank)
2. REPORT DATE
3. REPORT TYPE AND DATES COVERED
May 2001
Technical Report

4. TITLE AND SUBTITLE

Analysis of the Thermal Performance of Tierra I-A Low-Energy High-Mass Residence

5. FUNDING NUMBERS

6. AUTHOR(S)

Michael W. Smith

7. PERFORMING ORGANIZATION NAME(S) AND ADDRESS(ES)

8. PERFORMING ORGANIZATION

REPORT NUMBER

NREL/TP-550-25873

9. SPONSORING/MONITORING AGENCY NAME(S) AND ADDRESS(ES)

National Renewable Energy Laboratory

10. SPONSORING/MONITORING AGENCY REPORT NUMBER

1617 Cole Blvd.

Golden, CO 80401-3393

11. SUPPLEMENTARY NOTES

NREL Technical Monitor: NA

12a. DISTRIBUTION/AVAILABILITY STATEMENT

National Technical Information Service

12b. DISTRIBUTION CODE

U.S. Department of Commerce

5285 Port Royal Road

Springfield, VA 22161

13. ABSTRACT (Maximum 200 words)

A low-energy concrete house was designed using passive solar strategies to consume $70 \%$ less heating and cooling energy than a base case that conformed to the 1996 Home Energy Rating System (HERS) and the 1995 Model Energy Code (MEC).

The performance of this house was then evaluated using computer simulations and measured data.

The house, Tierra I, was monitored from July 22, 1996, through October 14, 1997. A Short Term Energy Monitoring (STEM) test was done November 19 to December 10, 1996. Computer simulations of the house were done using SUNREL, an updated version of the hourly data simulation package SERI-RES. The SUNREL model of the house was calibrated using both short- and long-term data.

The house achieved energy savings of $56 \%$, below the goal of $70 \%$. The lower than expected savings resulted from problems with the window modeling. As a result, during the design phase the solar gains were overestimated causing an underestimate in the level of insulation necessary to achieve the savings goal. For very low-energy passive solar buildings, it is apparent that very accurate window modeling is required. It also became apparent that accurate ground models are required as well because ground-heat loss accounts for a significant portion of the total heat loss in low-energy buildings.

\begin{tabular}{|c|c|c|c|}
\hline \multirow{2}{*}{\multicolumn{3}{|c|}{$\begin{array}{l}\text { 14. SUBJECT TERMS } \\
\text { LOW-energy buildings; house design; passive solar; SUNREL; Tierra I; STEM; HERS }\end{array}$}} & 15. NUMBER OF PAGES \\
\hline & & & 16. PRICE CODE \\
\hline $\begin{array}{l}\text { 17. SECURITY CLASSIFICATION } \\
\text { OF REPORT } \\
\text { Unclassified }\end{array}$ & $\begin{array}{l}\text { 18. SECURITY CLASSIFICATION } \\
\text { OF THIS PAGE } \\
\text { Unclassified }\end{array}$ & $\begin{array}{l}\text { 19. SECURITY CLASSIFICATION } \\
\text { OF ABSTRACT } \\
\text { Unclassified }\end{array}$ & $\begin{array}{l}\text { 20. LIMITATION OF ABSTRACT } \\
\text { UL }\end{array}$ \\
\hline
\end{tabular}

